\title{
Chemistry of Ground Water in the Silver Springs Basin, Florida, with an Emphasis on Nitrate
}

By G.G. Phelps

Prepared in cooperation with:

St. Johns River Water Management District

Southwest Florida Water Management District

Marion County

Florida Department of Environmental Protection

Scientific Investigations Report 2004-5144 


\title{
U.S. Department of the Interior Gale A. Norton, Secretary
}

\author{
U.S. Geological Survey \\ Charles G. Groat, Director
}

U.S. Geological Survey, Reston, Virginia: 2004

For sale by U.S. Geological Survey, Information Services

Box 25286, Denver Federal Center

Denver, CO 80225

For more information about the USGS and its products:

Telephone: 1-888-ASK-USGS

World Wide Web: http://www.usgs.gov/

Any use of trade, product, or firm names in this publication is for descriptive purposes only and does not imply endorsement by the U.S. Government.

Although this report is in the public domain, permission must be secured from the individual copyright owners to reproduce any copyrighted materials contained within this report.

Suggested citation: Phelps, G.G., 2004, Chemistry of Ground Water in the Silver Springs Basin, Florida, with an Emphasis on Nitrate: U.S. Geological Survey Scientific Investigations Report 2004-5144, $54 p$. 


\section{Contents}

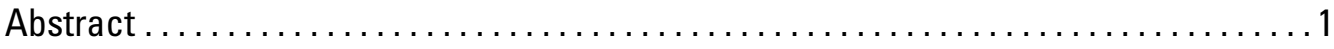

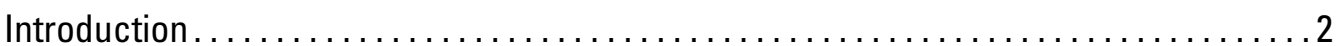

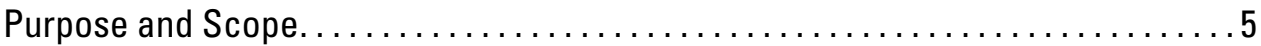

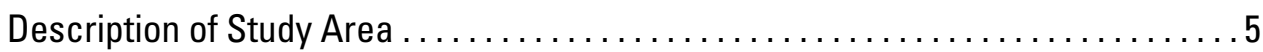

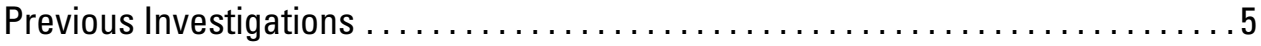

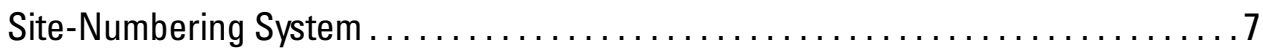

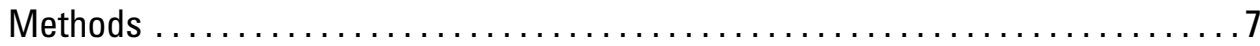

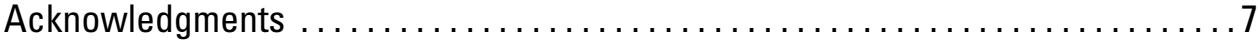

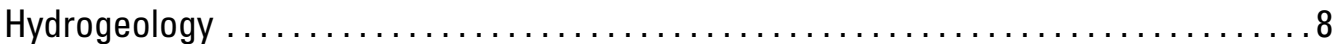

Hydrogeologic Units and Hydraulic Properties.......................

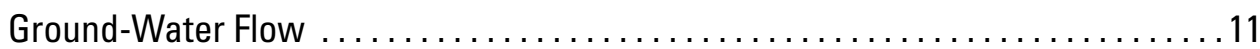

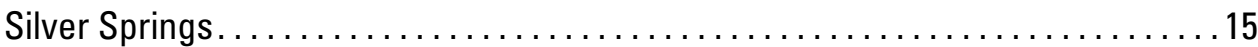

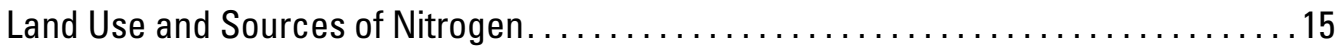

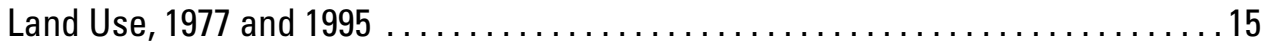

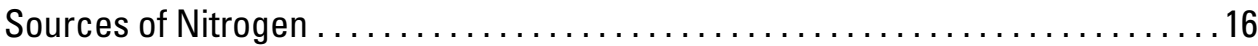

Land Use in the 10 -Year Contributing Area........................... 20

Chemistry of Ground and Spring Water................................. 20

Major lons and Trace Constituents ............................ 20

Dissolved Oxygen and Nutrients . . . . . . . . . . . . . . . . . . . . . 24

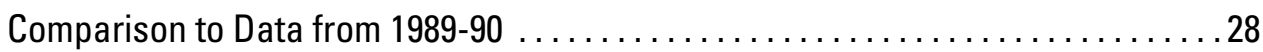

Relation of Nitrogen Concentrations to Land Use...................... 28

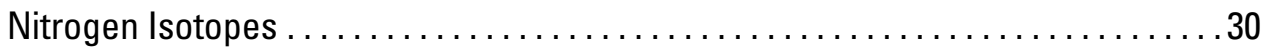

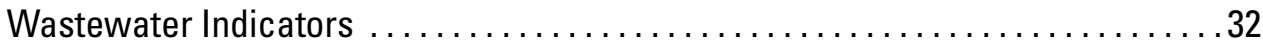

Dating Spring Water using Anthropogenic Tracers . . . . . . . . . . . . . . 36

Summary and Conclusions . . . . . . . . . . . . . . . . . . . . . . . . . . . . 40

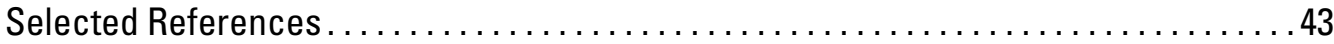

Appendix A. Water-Quality Data, 2001-2002 . . . . . . . . . . . . . . . . . . . . . . . 50

Appendix B. Land-Use and Geologic Codes .......................... 54

\section{Figures}

1. Map showing approximate extent of Silver Springs basin and potentiometric surface of the Upper Floridan aquifer, May $1999 . \ldots \ldots \ldots \ldots \ldots \ldots \ldots \ldots \ldots$

2. Graph showing concentration of nitrate- $\mathrm{N}$ in water from Silver Springs,

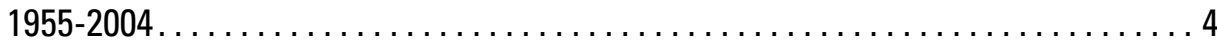

3. Graphs showing annual rainfall at 0 cala, Florida and discharge from Silver

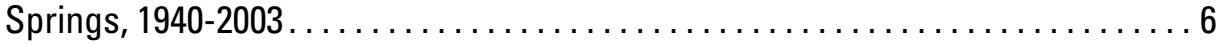

4. Chart showing hydrogeologic units in the Silver Springs basin ........... 8 
5-7. Maps showing:

5. Generalized geology of the Silver Springs basin and well sampling locations ........................................... 10

6. Potentiometric surface of the Upper Floridan aquifer in north-central Florida, May 2002, and areas contributing recharge to Silver Springs. ... 12

7. Potentiometric surface of the Upper Floridan aquifer in north-central Florida, September 2002, and areas contributing recharge to

Silver Springs. . . . . . . . . . . . . . . . . . . . . . . . 13

8. Diagram showing simulated volumetric flow budget for the surficial aquifer system, Upper Floridan aquifer, and Lower Floridan aquifer, in areas contributing recharge to Silver Springs based on travel times up to 500 years, as simulated by the Peninsular Florida Model for the average

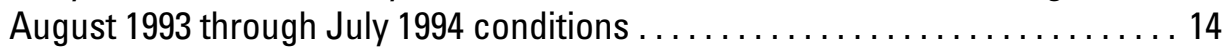

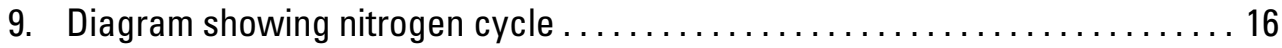

10. Map showing urban residential land use 1977 overlain on 1995 urban

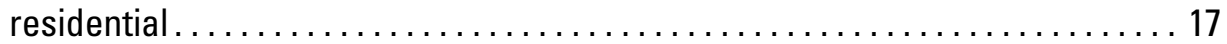

11. Graphs showing estimated annual nitrogen inputs for Marion County,

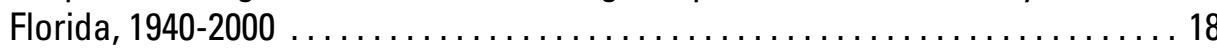

12. Maps showing 1977 and 1995 land use in the area contributing recharge to Silver Springs based on travel times up to 10 years $\ldots \ldots \ldots \ldots \ldots \ldots \ldots 21$

13. Boxplots showing ranges of calcium, sulfate, and nitrate- $\mathrm{N}$ concentrations for water samples collected in 1989-90 and during this study, 2001-02 . . . . 22

14. Graphs showing calcium and sulfate concentrations in water from the Silver Springs Main Spring, 1955-2003 ....................... 23

15. Map showing dissolved oxygen concentrations in water from the Upper

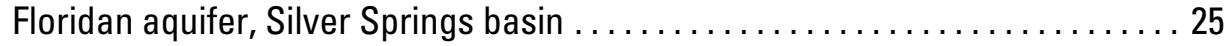

16. Map showing nitrate- $\mathrm{N}$ concentrations in water from the Upper Floridan aquifer, Silver Springs basin . . . . . . . . . . . . . . . . . . . . . . 26

17. Graph showing nitrate- $\mathrm{N}$ as a function of dissolved oxygen in ground-water

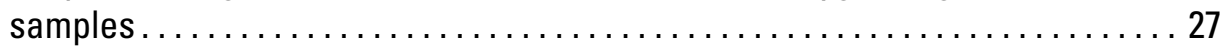

18. Boxplots showing total phosphorus and total orthophosphate in ground water, 1989-90 and 2000-01 ................................ 27

19. Boxplot showing range of ${ }^{15} \mathrm{~N} /{ }^{14} \mathrm{~N}$ for ground-water samples........... 30

20. Map showing areal distribution of ${ }^{15} \mathrm{~N} /{ }^{14} \mathrm{~N}$ for ground-water samples ...... 31

21. Map showing wells where the insecticide DEET was detected in

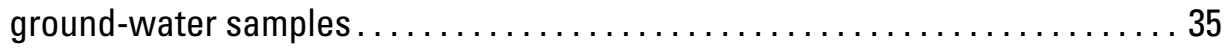

22. Graph showing concentrations of dissolved argon and $\mathrm{N}_{2}$ in water samples from Silver Springs compared to equilibrium concentrations of air in water . . 37

23. Graph showing comparison of measured tritium and tritiogenic helium concentrations of water samples from Silver Springs and the tritium concentration of rainfall at Ocala, Florida

\section{Tables}

1. Population and estimated nitrogen loads generated from wastewater in

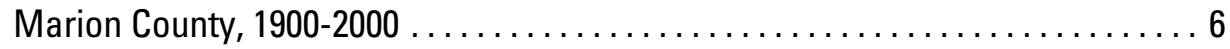

2. Comparison of historic and current nitrate- $\mathrm{N}$ concentrations in filtered ground-water samples 
3. Concentrations of nitrate- $\mathrm{N}$ in ground-water samples grouped by 1995 land use at well locations . . . . . . . . . . . . . . . . . . . . . . . . . 29

4. Isotopic data for water samples from Silver Springs, 2001-2002 . . . . . . . . . 32

5. Summary of compounds commonly detected in wastewater and detections

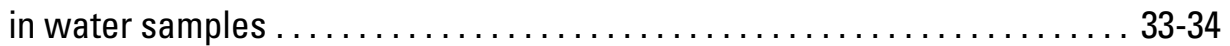

6. Dissolved gas data and summary of sulfur hexafluoride data for water samples collected at Silver Springs, January 29, 2002 . . . . . . . . . . . . . 37

7. Summary of tritium-helium age data using piston-flow model for water samples collected at Silver Springs, January $29,2002 \ldots \ldots \ldots \ldots \ldots \ldots \ldots 38$

8. Concentrations of chlorofluorocarbons in water samples collected at

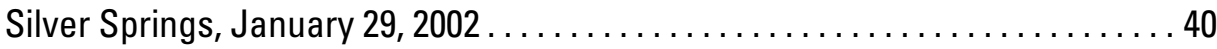

\section{Conversion Factors and Vertical Datum}

\begin{tabular}{|c|c|c|}
\hline Multiply & By & To obtain \\
\hline \multicolumn{3}{|c|}{ Length } \\
\hline inch (in.) & 2.54 & centimeter $(\mathrm{cm})$ \\
\hline foot $(\mathrm{ft})$ & 0.3048 & meter $(\mathrm{m})$ \\
\hline mile (mi) & 1.609 & kilometer (km) \\
\hline \multicolumn{3}{|c|}{ Area } \\
\hline \multirow[t]{2}{*}{ square mile $\left(\mathrm{mi}^{2}\right)$} & 2.59 & square kilometer $\left(\mathrm{km}^{2}\right)$ \\
\hline & Volume & \\
\hline \multirow[t]{2}{*}{ gallon (gal) } & 3.785 & liter (L) \\
\hline & Mass & \\
\hline \multirow[t]{2}{*}{ pound (lb) } & 0.4536 & kilogram (kg) \\
\hline & Flow Rate & \\
\hline cubic foot per second $\left(\mathrm{ft}^{3} / \mathrm{s}\right)$ & 0.02832 & $\begin{array}{l}\text { cubic meter per second } \\
\left(\mathrm{m}^{3} / \mathrm{s}\right)\end{array}$ \\
\hline gallon per day (gal/d) & 0.003785 & cubic meter per day $\left(\mathrm{m}^{3} / \mathrm{d}\right)$ \\
\hline $\begin{array}{r}\text { million gallons per day } \\
(\mathrm{Mgal} / \mathrm{d})\end{array}$ & 0.04381 & $\begin{array}{l}\text { cubic meter per second } \\
\left(\mathrm{m}^{3} / \mathrm{s}\right)\end{array}$ \\
\hline \multirow[t]{2}{*}{ inch per year (in/yr) } & 25.4 & millimeter per year $(\mathrm{mm} / \mathrm{yr})$ \\
\hline & ${ }^{*}$ Transmissivity & \\
\hline foot squared per day $\left(\mathrm{ft}^{2} / \mathrm{d}\right)$ & 0.09290 & meter squared per day $\left(\mathrm{m}^{2} / \mathrm{d}\right)$ \\
\hline
\end{tabular}

*The standard unit for transmissivity is cubic foot per day per square foot times foot of aquifer thickness $\left[\left(\mathrm{ft}^{3} / \mathrm{d}\right) / \mathrm{ft}^{2}\right] \mathrm{ft}$. In this report, the mathematically reduced form, foot squared per day $\left(\mathrm{ft}^{2} / \mathrm{d}\right)$, is used for convenience.

Temperature in degrees Fahrenheit $\left({ }^{\circ} \mathrm{F}\right)$ may be converted to degrees Celsius $\left({ }^{\circ} \mathrm{C}\right)$ as follows: ${ }^{\circ} \mathrm{C}=\left({ }^{\circ} \mathrm{F}-32\right) / 1.8$.

Vertical coordinate information is referenced to the National Geodetic Vertical Datum of 1929 (NGVD 29).

Horizontal coordinate information (latitude-longitude) is referenced to the North American Datum of 1927 (NAD 27): 


\section{Abbreviations and Acronyms}

\begin{tabular}{|c|c|}
\hline $\mathrm{NH}_{4}^{+}$ & ammonium \\
\hline $\mathrm{Ar}$ & argon \\
\hline B & boron \\
\hline CFCs & chlorofluorocarbons \\
\hline DEET & $\mathrm{N}, \mathrm{N}$-diethyl-meta-toluamide \\
\hline DO & dissolved oxygen \\
\hline FDACS & $\begin{array}{l}\text { Florida Department of Agriculture and } \\
\text { Consumer Services }\end{array}$ \\
\hline FDEP & $\begin{array}{l}\text { Florida Department of Environmental } \\
\text { Protection }\end{array}$ \\
\hline GIS & geographic information system \\
\hline$>$ & greater than \\
\hline$<$ & less than \\
\hline $\mathrm{Mn}$ & manganese \\
\hline MCL & Maximum Contaminant Level \\
\hline$\mu \mathrm{g} / \mathrm{L}$ & micrograms per liter \\
\hline$\mu$ & micron \\
\hline $\mathrm{MCU}$ & middle confining unit \\
\hline MSCU & middle semiconfining unit \\
\hline $\mathrm{mg} / \mathrm{L}$ & milligrams per liter \\
\hline $\mathrm{mL}$ & milliliter \\
\hline $\mathrm{mm}$ & millimeter \\
\hline NADP & National Atmospheric Deposition Program \\
\hline NAWQA & National Water Quality Assessment \\
\hline $\mathrm{Ne}$ & neon \\
\hline $\mathrm{NO}_{3}^{-}$ & nitrate \\
\hline $\mathrm{NO}_{2}^{-}$ & nitrite \\
\hline $\mathrm{N}$ & nitrogen \\
\hline $\mathrm{N}_{2}$ & nitrogen gas \\
\hline${ }^{15} \mathrm{~N} /{ }^{14} \mathrm{~N}$ & nitrogen isotopes \\
\hline OSDS & onsite sewage disposal systems \\
\hline $\mathrm{P}$ & phosphorus \\
\hline $\mathrm{SF}_{6}$ & sulfur hexafluoride \\
\hline${ }^{3} \mathrm{He}_{\text {trit }}$ & tritogenic helium or helium-3 \\
\hline${ }^{3} \mathrm{H} /{ }^{3} \mathrm{He}_{\text {trit }}$ & tritium/helium-3 \\
\hline $\mathrm{TU}$ & tritium units \\
\hline USGS & U.S. Geological Survey \\
\hline
\end{tabular}




\title{
Chemistry of Ground Water in the Silver Springs Basin, Florida, with an Emphasis on Nitrate
}

\author{
By G.G. Phelps
}

\begin{abstract}
The Silver Springs group, in central Marion County, Florida, has a combined average discharge rate of 796 cubic feet per second and forms the headwaters of the Silver River. The springs support a diverse ecosystem and are an important cultural and economic resource. Concentrations of nitrite-plus-nitrate (nitrate-N) in water from the Main Spring increased from less than 0.5 milligrams per liter $(\mathrm{mg} / \mathrm{L})$ in the 1960 s to about $1.0 \mathrm{mg} / \mathrm{L}$ in 2003 . The Upper Floridan aquifer supplies the ground water to support spring discharge. This aquifer is at or near land surface in much of the ground-water basin; nutrients leached at land surface can easily percolate downward into the aquifer. Sources of nitrogen in ground water in the Silver Springs basin include atmospheric deposition, fertilizers used by agricultural and urban activities, and human and animal wastes.
\end{abstract}

During 2000-2001, 56 wells in the area contributing recharge to Silver Springs were sampled for major ions, nutrients, and some trace constituents. Selected wells also were sampled for a suite of organic constituents commonly found in domestic and industrial wastewater and for the ratio of nitrogen isotopes $\left({ }^{15} \mathrm{~N} /{ }^{14} \mathrm{~N}\right)$ to better understand the sources of nitrate. Wells were selected to be representative of both confined and unconfined conditions of the Upper Floridan aquifer, as well as a variety of land-use types. Data from this study were compared to data collected from 25 wells in 1989-90. Concentrations of nitrate- $\mathrm{N}$ in ground water during this study ranged from less than the detection limit of 0.02 to $12 \mathrm{mg} / \mathrm{L}$, with a median of $1.2 \mathrm{mg} / \mathrm{L}$. For data from 1989-90, the range was from less than 0.02 to $3.6 \mathrm{mg} / \mathrm{L}$, with a median of $1.04 \mathrm{mg} / \mathrm{L}$.
Water from wells in agricultural land-use areas had the highest median nitrate- $\mathrm{N}$ concentration $(1.7 \mathrm{mg} / \mathrm{L})$, although it is uncertain if the $12 \mathrm{mg} / \mathrm{L}$ maximum concentration was influenced by land-use activities or proximity to a septic tank. The median value for all urban land-use areas was $1.15 \mathrm{mg} / \mathrm{L}$. Because fewer wells were in rangeland or forested areas, those categories were grouped together. The median concentration for that group was $0.09 \mathrm{mg} / \mathrm{L}$.

The ratio of ${ }^{15} \mathrm{~N} /{ }^{14} \mathrm{~N}$ in ground-water samples ranged from -0.5 to 11.5 per mil. The median value for groundwater samples from 35 wells, 4.9 per mil, is near the top of the range that indicates inorganic nitrogen sources. In agricultural areas, the median ${ }^{15} \mathrm{~N} /{ }^{14} \mathrm{~N}$ was 4.8 per mil, indicating mostly inorganic (fertilizer) sources. In urban areas, the median ${ }^{15} \mathrm{~N} /{ }^{14} \mathrm{~N}$ was 5.4 per mil, indicating more influence of organic nitrogen $(\mathrm{N})$ sources. Thus, in both agricultural and urban areas, fertilizer is an important inorganic source of $\mathrm{N}$ in ground water (and, therefore, in spring water as well). The influence of organic $\mathrm{N}$ is more apparent in urban areas than in agricultural areas. Two distinct ${ }^{15} \mathrm{~N} /{ }^{14} \mathrm{~N}$ values were observed in water from the Main Spring, one indicating an inorganic nitrogen source and the other indicating a mixture of sources with a strong influence of organic nitrogen.

Thirty-five wells and three springs of the Silver Springs group (the Main Spring, the Abyss, and the Blue Grotto) were sampled for a suite of 63 compounds common in wastewater. A total of 38 compounds was detected, nearly all in very low concentrations. The most frequently detected compound was the insecticide N,Ndiethyl-meta-toluamide (DEET), which was detected in water from 27 wells and all three springs. The presence or 


\section{Chemistry of Ground Water in the Silver Springs Basin, Florida, with an Emphasis on Nitrate}

absence of DEET in ground-water samples did not seem to be related to land use; however, hydrogeologic conditions at the well sites (confined or unconfined) generally did affect the presence or absence of DEET in the ground water. DEET also appears to be a useful tracer for the presence of reused water.

Water samples were collected from the Main Spring and two other springs of the Silver Springs group and analyzed for concentrations of dissolved gasses and for chlorofluorocarbons (CFCs), sulfur hexafluoride, and tritium/helium-3 for the purpose of dating the young fraction of ground water. Apparent ground-water ages are based on a piston-flow model, which may not adequately represent a complex flow system. Apparent age for water from the Main Spring is about 27 years for tritium/ helium-3 data, compared to about 15 years based on sulfur hexafluoride. For the Abyss, the tritium/helium age is about 9 years and the sulfur hexafluoride age is about 8 years. For the Blue Grotto, the tritium/helium-3 age is about 19 years, whereas the sulfur hexafluoride age is about 6 years. These results indicate that the flow system to the Abyss may be relatively shallow and rapid and adequately represented by the piston flow model, whereas the flow systems of the other springs are more complex, probably involving mixing with water from deeper zones of the aquifer. Both the nitrogen isotope and tritium/ helium-3 data from the Main Spring apparently indicate that the mixture of spring discharge from predominantly young to mostly older water can change rapidly and may not be easily related to discharge rate. CFC data could not be used for dating because all spring samples contained higher than equilibrium concentrations of CFCs from atmospheric sources.

All three springs are affected by the presence of wastewater in the contributing area, as evidenced by the presence of DEET and high CFC concentrations in all the samples. Although the conduit flow system contributing water to Silver Springs is complex and likely involves mixing of water from both shallow and deep flow zones, the fact that the water is relatively young (less than 30 years) indicates the importance of minimizing nitrogen loading within a contributing area that has ground-water travel times of 30 years or less.

\section{Introduction}

Silver Springs, in central Marion County, Florida (fig. 1), is the largest nontidal spring group in Florida, with an average discharge of 796 cubic feet per second $\left(\mathrm{ft}^{3} / \mathrm{s}\right)$ for 1932-2002 (U.S. Geological Survey, 2003b).
The spring group is an important natural feature, forming the headwaters of the Silver River, and supporting a diverse ecosystem that includes numerous species of fish, birds, and reptiles. It also is a significant recreational, cultural, and economic asset for north-central Florida. Ground water from the Floridan aquifer system (a thick sequence of carbonate rocks of Eocene age) supports the spring discharge and is the sole source of potable water within the basin. The Floridan aquifer system is divided into the Upper and Lower Floridan aquifers, separated by a middle semiconfining unit. The area contributing recharge to the spring group, called a ground-water basin or springshed, includes approximately 1,200 square miles $\left(\mathrm{mi}^{2}\right)$ in parts of Marion, Alachua, Putnam, Lake, and Sumter Counties, Florida. In much of the basin, the limestone of the Floridan aquifer system is at or near land surface, and recharge to the aquifer occurs rapidly.

Nitrogen $(\mathrm{N})$ occurs as anions in water as nitrite $\left(\mathrm{NO}_{2}^{-}\right)$or nitrate $\left(\mathrm{NO}_{3}{ }^{-}\right)$. Both species are very mobile and $\mathrm{NO}_{3}{ }^{-}$is stable over a wide range of conditions (Hem, 1985). The $\mathrm{NO}_{2}{ }^{-}$ion is unstable in aerated water and generally is present in negligible concentrations. In this report, the combined concentration of nitrite-plus-nitrate reported by the laboratory is referred to as nitrate-N.

Nitrate-N concentration in the water from Silver Springs (and thus the concentration in Silver River) has increased since the mid 1950s (fig. 2). Elevated nitrate concentrations in surface waters may result in the growth of nuisance vegetation such as water hyacinth and hydrilla. Dense growth of such vegetation can result in oxygen depletion in the water beneath the vegetative mass due to plant death and subsequent decay (Nordlie, 1990). Also, increased nitrate concentrations may increase the growth of phytoplankton if growth is nitrogen limited, thus reducing water clarity.

Hydrogeologic conditions in the Upper Floridan aquifer, particularly the degree of aquifer confinement, may significantly affect the potential for nitrate enrichment of ground water. In areas where the Upper Floridan aquifer is unconfined-as is the case throughout most of the basin-nutrients leached at land surface quickly percolate vertically into the aquifer. In more localized areas where the aquifer is confined by fine-grained or lower-permeability sediments, although the vertical hydraulic gradient is downward, the lower-permeability sediments retard the movement of nutrient-enriched water. The Upper Floridan aquifer also has well-developed secondary porosity and is highly transmissive; thus, nutrient-enriched ground water can flow a given distance within a relatively short period of time (weeks to months). 


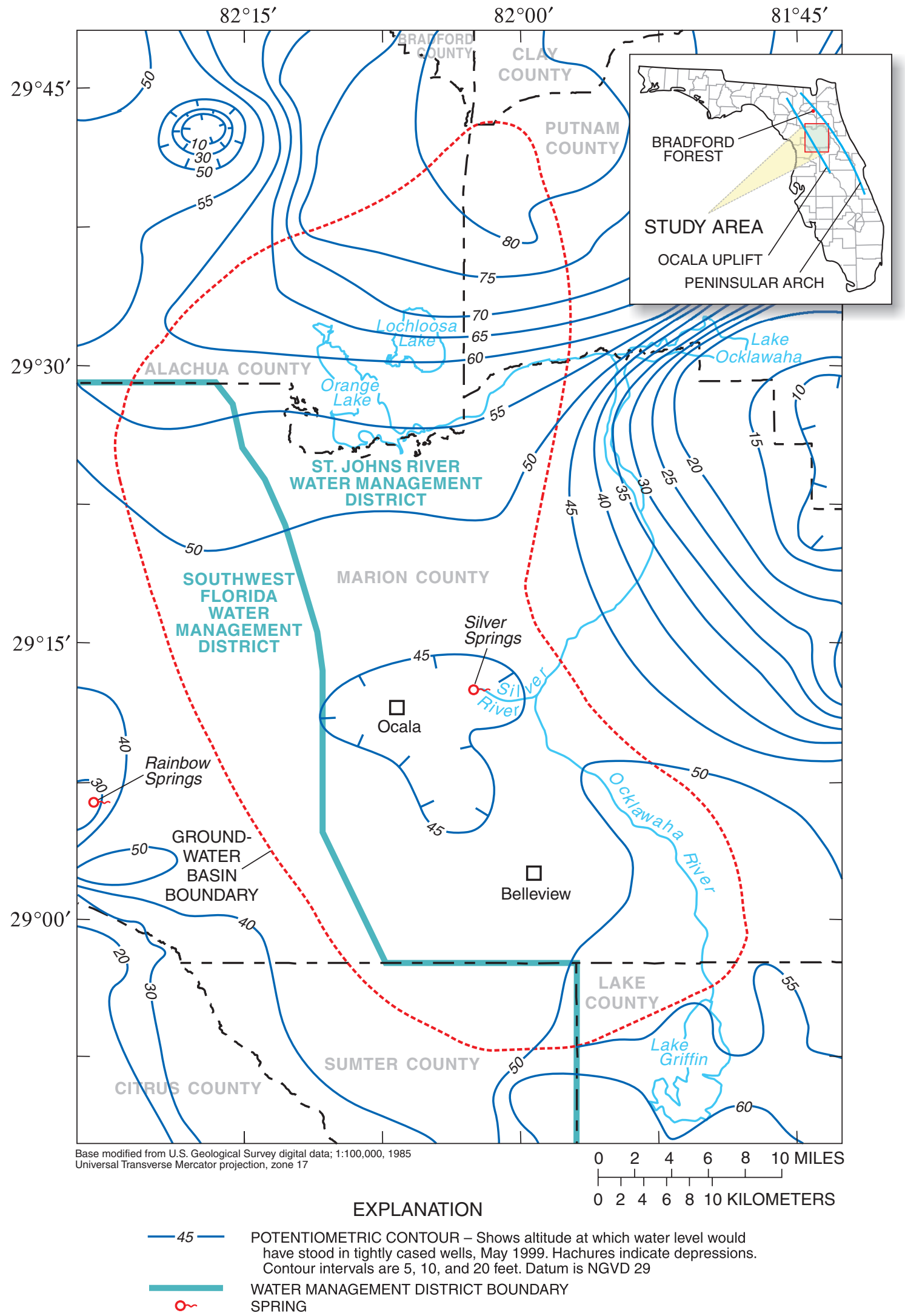

Figure 1. Approximate extent of Silver Springs basin and potentiometric surface of the Upper Floridan aquifer, May 1999 (from Bradner and Knowles, 1999). 


\section{Chemistry of Ground Water in the Silver Springs Basin, Florida, with an Emphasis on Nitrate}

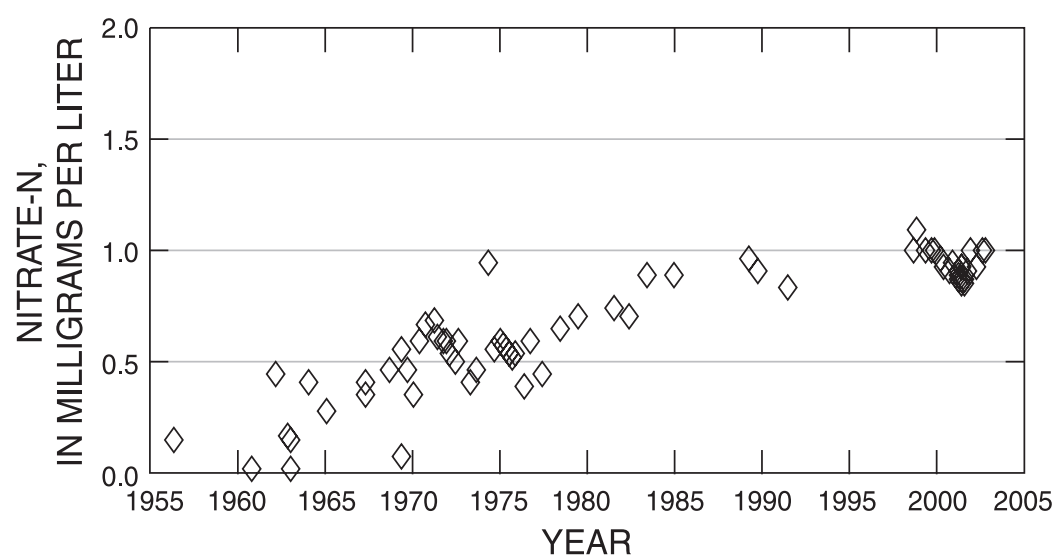

Figure 2. Concentration of nitrate- $\mathrm{N}$ in water from Silver Springs, 1955-2004.
For example, Knochenmus (1967) reported a dye-trace travel time in the Ocala area of 1.3 miles in less than 1 week. Because the basin generally is internally drained, most of the water that recharges the aquifer eventually is discharged either by pumping wells or at Silver Springs.

Land-use activities within the Silver Springs basin in Marion County historically have been predominantly agricultural. However, the City of Ocala continues to experience rapid population growth, as do surrounding rural areas that have become increasingly attractive for development as retirement communities. These communities often include golf courses and residential areas with turf that require fertilization. Of particular concern is the potential for nutrients leached from these fertilizers to enter the Upper Floridan aquifer. In addition, in 1990, only about 35 percent of dwellings in Marion County were served by public sewage treatment facilities; the remainder presumably use onsite sewage disposal systems (OSDS), usually called septic tanks (U.S. Census Bureau, 2002).

Nitrate concentrations greater than 10 milligrams per liter $(\mathrm{mg} / \mathrm{L})$ present a health hazard (primarily for infants) and exceed the primary drinking-water standard established by the U.S. Environmental Protection Agency (2003). In 1994, nitrate concentrations as high as 5.2 $\mathrm{mg} / \mathrm{L}$ were observed in ground water in the adjacent Rainbow Springs basin (Jones and others, 1996, appendix II). Results of sampling 20 wells in the Silver Springs basin in 1989-90 indicated a range of nitrate- $\mathrm{N}$ concentrations from less than 0.02 to $3.6 \mathrm{mg} / \mathrm{L}$, with a median of $1.2 \mathrm{mg} / \mathrm{L}$ (Phelps, 1994). In the decade between that study and the one described in this report, only three wells in the basin sampled previously (as part of the Florida Department of Environmental Protection (FDEP) Very Intensely Studied Area network) were resampled.
To assess the possible effects of past and present landuse activities on water quality in the Silver Springs basin, and thus, the potential for future land-use changes to degrade ground-water quality, existing chemical constituent concentrations in ground water need to be documented. Also, an assessment is needed of how nutrient concentrations, particularly nitrate (because of its mobility in groundwater systems), may vary as a function of localized hydrogeologic conditions (that is, unconfined or semiconfined aquifer) as well as with land use. A basin-wide evaluation of the occurrence and distribution of nitrate in the Silver Springs basin will enhance understanding of the processes by which nutrients enter and move through the groundwater flow system. The results will help area planners and water-resource managers formulate recommendations for design of new developments, and thus minimize the potential for ground water to become contaminated from changes to existing land-use activities. Also, by providing a baseline of current conditions, managers will be better able to quantify changes in ground-water chemistry that may occur with future development. Results may also be useful in helping planners identify areas, based on differences in hydrogeologic conditions, where ground-water quality is most (or least) likely to be affected by development. Finally, the results will provide useful information for designing more effective monitoring-well networks needed to identify changes in ground-water quality in the future. To meet these objectives, the U.S. Geological Survey (USGS), in cooperation with the St. Johns River Water Management District (SJRWMD), the Southwest Florida Water Management District (SFWMD), Marion County, and FDEP, began a 4year study in 1999 to document the chemistry of ground water in the Silver Springs basin, with an emphasis on the occurrence and distribution of nitrate- $\mathrm{N}$ and to relate, if possible, nitrate occurrence and concentrations with current and past land-use activities and selected hydrogeologic conditions. 


\section{Purpose and Scope}

This report presents the results of sampling 56 wells and three springs of the Silver Springs group for major and selected trace constituents, nutrients and field measurements of temperature, $\mathrm{pH}$, specific conductance, and dissolved oxygen. Selected wells and the three springs also were sampled for nitrogen isotopes $\left({ }^{15} \mathrm{~N} /{ }^{14} \mathrm{~N}\right)$ and a suite of organic constituents commonly found in domestic and industrial wastewater. The springs were sampled for chlorofluorocarbons (CFCs), sulfur hexafluoride, dissolved gasses, and the ratio of tritium to helium-3 $\left({ }^{3} \mathrm{H} /{ }^{3} \mathrm{He}_{\text {trit }}\right)$ to provide information for dating the spring water. Although the study area includes the entire ground-water basin, emphasis was placed on the areas relatively close to the spring group and also on the southern half of Marion County, where the most rapid development activities are expected to occur. Land-use information for 1977 and 1995 were compiled into geographic information system (GIS) coverages so that the effects of land use on ground-water chemistry could be evaluated. Estimates were made of historic nitrogen loading to the basin by compiling fertilizer sales and recommended application data, atmospheric deposition data, rates of nitrogen production by farm animals, and loads from wastewater. By adding particle tracking to a ground-water flow model (Sepúlveda, 2002), areas contributing recharge to Silver Springs for various travel times were delineated.

\section{Description of Study Area}

The Silver Springs ground-water basin, as delineated on the basis of the potentiometric surface of the Upper Floridan aquifer in May 1999 (Bradner and Knowles, 1999), encompasses about $1,200 \mathrm{mi}^{2}$ in north-central Florida (fig. 1), although fluctuations in the altitude of the potentiometric surface can result in minor variations in the size of the basin. The potentiometric surface of May 1999 generally represents conditions at the end of the dry season. The gently rolling topography results from the combination of karst depressions caused by dissolution of limestone and hills capped with less permeable sediments that retard dissolution. Land-surface altitudes range from about 65 to 180 feet (ft) above NGVD 29. The area is characterized by an almost complete absence of surface drainage. Most of the drainage is internal, either directly into closed depressions or by seepage into the unconfined limestone of the Upper Floridan aquifer. Ground-water basins in the area do not coincide with the boundaries of surface-water drainage divides (Faulkner, 1973).
Climate of the area is humid subtropical, with hot, rainy summers and cool, generally dry winters. Annual rainfall averages about 54 inches per year (in/yr) and the average air temperature is about $71^{\circ} \mathrm{F}$ (National Oceanic and Atmospheric Administration, 2003). A drought in 2000-2002 resulted in the lowest flow measurement on record for the Silver Springs group, $350 \mathrm{ft}^{3} / \mathrm{s}$ in June 2001 (fig. 3). The average flow for 1932-2002 was about $790 \mathrm{ft}^{3} / \mathrm{s}$.

Population in Marion County, as in many parts of Florida, has increased significantly (table 1). From 19702000, the population increased about 275 percent. Marion County has changed from predominantly rural to a mixture of urban-suburban-rural land uses. The growth of Florida as a retirement destination has resulted in the development of numerous subdivisions, many of which include golf courses. Areas that once were thoroughbred horse farms were redeveloped as retirement communities or shopping areas.

\section{Previous Investigations}

Previous studies of the ground-water resources of Marion County and the Silver Springs area include three investigations focused on the potential effects of the proposed Cross-Florida Barge Canal: Knochenmus (1967) investigated ground-water travel times by using dye traces; Faulkner (1973) conducted a study of the stratigraphy, structural geology, ground-water flow system, and ground-water chemistry in central Marion County; and Tibbals (1975) conducted aquifer tests in the Upper Floridan aquifer in the proposed canal right-ofway. Information about drainage wells in Ocala was collected by Kimrey and Fayard (1984); a report by Environmental Resources Management-South, Inc., (1988) documented contamination of the Upper Floridan aquifer in downtown Ocala. The hydrogeology, ground-water quality, and potential for contamination of the Upper Floridan aquifer in the Silver Springs basin were described by Phelps (1994). Ground-water flow conditions in the adjacent Rainbow Springs basin were described by Geo-Trans, Inc., (1988). Evapotranspiration rates in both the Silver Springs and Rainbow Springs basins were estimated by Knowles (1996). A detailed analysis of the sources of nitrate in water discharging from Rainbow Springs was presented by Jones and others (1996). Isotope concentrations of water from Silver Springs and other springs in Marion County were reported by Toth (1999 and 2003). 

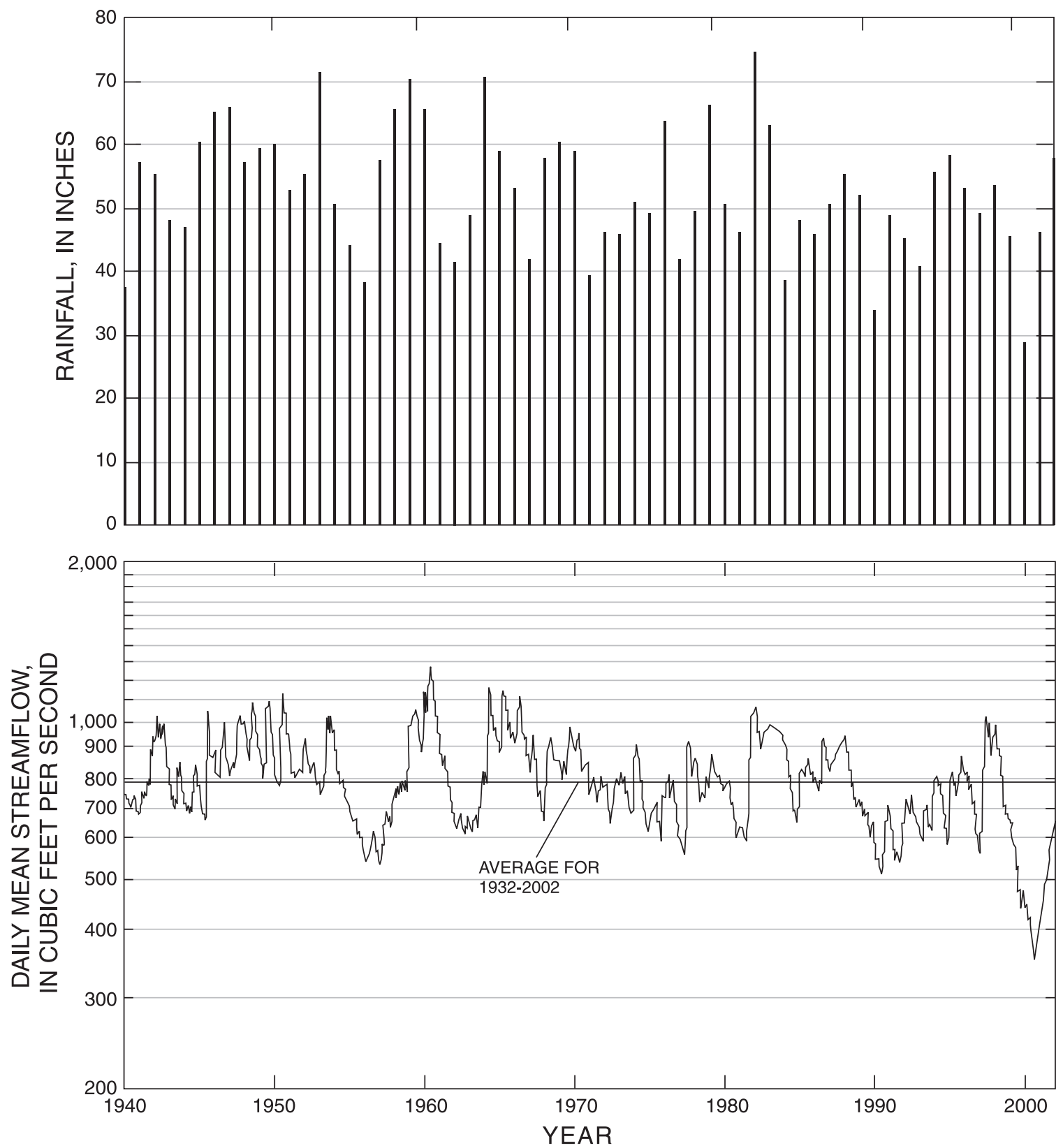

Figure 3. Annual rainfall at Ocala, Florida, and discharge from Silver Springs, 1940-2003.

Table 1. Population and estimated nitrogen loads generated from wastewater in Marion County, Florida, 1900-2000.

[Source of population numbers: U.S. Census Bureau, 2002. Nitrogen loads in kilograms per year, based on a per capita estimate of 4.09 kilograms per year from Otis and others, 1993]

\begin{tabular}{cccccccccccc}
\hline \multicolumn{1}{c}{ Year } & 1900 & 1910 & 1920 & 1930 & 1940 & 1950 & 1960 & 1970 & 1980 & 1990 & 2000 \\
\hline Total population & 24,403 & 26,941 & 23,968 & 29,578 & 31,243 & 38,187 & 51,616 & 69,030 & 122,488 & 194,833 & 258,916 \\
Nitrogen loads & 99,808 & 110,189 & 98,029 & 120,974 & 127,784 & 156,185 & 211,109 & 282,333 & 500,976 & 796,867 & $1,058,966$ \\
\hline
\end{tabular}




\section{Site-Numbering System}

The USGS National Water Data Information System uses a 15-digit number (site identification number) based on latitude and longitude to identify wells. The first six digits denote the degrees, minutes, and seconds of latitude; the next seven digits denote the degrees, minutes, and seconds of longitude; and the last two digits denote a sequential number for a site within a one-second grid. Well site identification numbers generally end in " 01 " or "02." For convenience, in this report wells also are given a sequential well number (listed in app. A) that refers to well locations shown in the figures. Surface-water sites that are part of the USGS data-collection network are identified by an 8-digit downstream order number. The 8-digit site identification number for Silver Springs (Main Spring) is 02329500. Miscellaneous surface-water quality data-collection sites generally are assigned 15digit numbers based on latitude and longitude and ending in sequence number " 00 ."

\section{Methods}

During this study, water samples were collected from 56 wells and three springs of the Silver Springs group. Most of the wells were in regular use and equipped with a dedicated pump. A few wells did not have pumps and were purged and sampled with a portable electric submersible pump. Wells were purged until at least three casing volumes had been removed and until temperature, $\mathrm{pH}$, and specific conductance had stabilized. Water samples for major ions and nutrients were collected according to protocols described by the U.S. Geological Survey (1997-2003) and analyzed at the USGS laboratory in Ocala, Fla. Samples analyzed for nutrients were kept in the field at $4{ }^{\circ} \mathrm{C}$ before being taken to the lab. Water samples for anion and cation analysis were filtered by using 0.45-micron $(\mu)$ Gelman capsule filters. Cation and trace metal samples were collected in acid-washed bottles and acidified with 70 percent nitric acid.

Isotopic values were reported with the standard delta notation $(\delta)$ (Gonfiantini, 1981) as defined by the expression:

$$
\delta(\text { per mil })=\left[\left(\mathrm{R}_{\text {sample }} / \mathrm{R}_{\text {standard }}\right)-1\right] \times 1,000 .
$$

For $\delta^{15} \mathrm{~N}, \mathrm{R}={ }^{15} \mathrm{~N} /{ }^{14} \mathrm{~N}$. Samples for nitrogen isotope analysis were filtered and collected in 1-liter (L) brown plastic bottles, kept chilled at $4{ }^{\circ} \mathrm{C}$, and shipped by the USGS central laboratory in Denver, Colo., to a contract laboratory. Nitrite-plus-nitrate was extracted by using Devarda's reduction and $\delta^{15} \mathrm{~N}$ was determined by using mass spectrometric analysis with analytical uncertainties of about \pm 0.2 per mil.

Samples from springs were collected by lowering a positive displacement dual-piston (Bennett) pump head from the water surface down to the spring vent. Water was pumped through $0.63-\mathrm{cm}$ diameter copper tubing (refrigerator grade). Water samples for ${ }^{3} \mathrm{H} /{ }^{3} \mathrm{He}_{\text {trit }}$ analyses were collected in pinch-off copper tubes (10 mm diameter, 80 $\mathrm{cm}$ length, approximately $40 \mathrm{~mL}$ volume) while applying back pressure to the discharge from the sample tube to prevent formations of gas bubbles during sample collection. These samples were analyzed at the Noble Gas Laboratory of Lamont-Doherty Earth Observatory at Columbia University using quantitative gas extraction by mass spectrometric techniques (Schlosser and others, 1989) and Ludin and others (1998). Water samples for CFC analysis were collected in glass ampules that were sealed in the field. Water samples for dissolved gas analysis were collected in septum glass vials; samples for sulfur hexafluoride $\left(\mathrm{SF}_{6}\right)$ analysis were collected in glass bottles and shipped to the USGS CFC laboratory in Reston, Va. Both $\mathrm{CFC}$ and $\mathrm{SF}_{6}$ concentrations are determined by GC-ECD (gas chromatography with electron capture detection) (Busenberg and Plummer, 1992 and 2000).

Water samples for analysis of organic constituents commonly found in domestic and industrial wastes were collected in 1-L amber glass bottles which had been baked at $350{ }^{\circ} \mathrm{C}$. The samples were chilled at $4{ }^{\circ} \mathrm{C}$, and shipped to the USGS Central Laboratory in Denver, Colo., where they were filtered through a $0.7-\mu$ glass fiber filter before extraction. For quality assurance purposes, replicate samples and field blank samples were collected during each sampling trip. Because compounds such as caffeine and insecticides were included in the analysis, field personnel neither consumed caffeine nor used personal insecticides on sampling days. Samples were analyzed by using gas chromatography and mass spectrometry, as described by Zaugg and others (2002).

\section{Acknowledgments}

The author is grateful to Julian Wayland (USGS, Reston, Va.) and Gen Phelps, USGS Volunteer for Science, for assistance with field data collection. Helpful discussions and comments were provided by Brian Katz (USGS, Tallahassee, Fla.), Amy Swancar (USGS, Tampa, Fla.), and L. Niel Plummer, (USGS, Reston, Va.). 


\section{Chemistry of Ground Water in the Silver Springs Basin, Florida, with an Emphasis on Nitrate}

\section{Hydrogeology}

The hydrogeology of the Silver Springs basin was described in detail by Faulkner (1973). The Florida Plateau is a large, tectonically stable platform of carbonate rocks that overlie the post-Paleozoic Coastal Plain floor. In central Marion County, the sedimentary rocks are about 4,000 ft thick of which about 1,500 to $2,500 \mathrm{ft}$ are Tertiary age and younger. The geologic formations of interest in the study area are the Avon Park Formation, the Ocala Limestone, the Hawthorn Group, and unconsolidated post-Miocene sediments (fig. 4). The Avon Park Formation, of middle Eocene age, is composed of alternating layers of hard to very hard dark-brown dolomite and softer, light-brown to tan limestone. The Avon Park Formation is highly fractured and contains cavities. The Ocala Limestone is composed of soft white to cream to tan limestone which usually is fossiliferous, with occasional inclusions of chert. An erosional unconformity separates

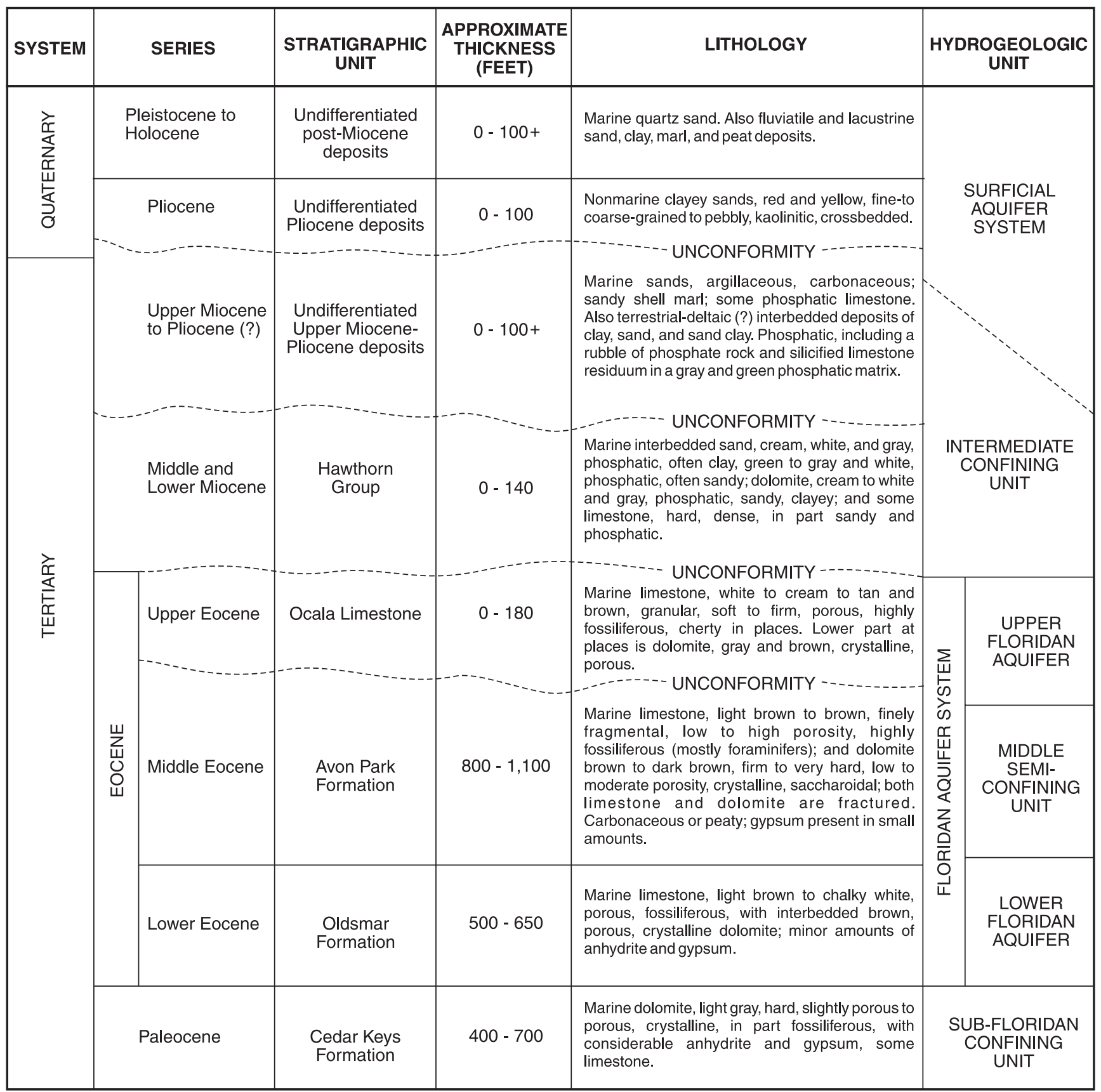

Figure 4. Hydrogeologic units in the Silver Springs basin (from Faulkner, 1973, and Scott and others, 2001). 
the Avon Park Formation from the overlying Ocala Limestone. In some parts of Marion County, the Ocala Limestone has been substantially eroded and the Avon Park Formation occurs near land surface.

The Hawthorn Group of Miocene age unconformably overlies the Ocala Limestone and, where present, ranges in thickness from a few feet to more than $100 \mathrm{ft}$ in the eastern part of Marion County. Hawthorn Group sediments consist mostly of quartz sand interbedded with clay, sandy phosphatic clay, and hard, dense limestone or dolostone. The stratigraphy and occurrence of the Hawthorn Group was described by Scott (1988). In much of western Marion County, the Hawthorn Group has been eroded; the remaining deposits commonly form caps on hilltops. East of the Ocklawaha River, the Hawthorn is present as a continuous layer; the resulting expression at land surface is a change from rolling karst hills in the western part of the County to a more flat, often poorly drained landform. Overlying the Hawthorn Group in parts of Marion County are a variety of mostly clastic deposits that range in age from Pliocene to Holocene (fig. 5) and in thickness from 0 to about $100 \mathrm{ft}$. In most of the Silver Springs ground-water basin, the thickness of sediments overlying the Ocala Limestone ranges from 10 to $50 \mathrm{ft}$.

Two regional structural features are important in the study area: the Peninsular Arch and the Ocala Uplift (fig. 1). The Peninsular Arch is the primary structural control for sediments deposited during Cretaceous and early Tertiary time (Faulkner, 1973). The axis of the Peninsular Arch runs from northwest to southeast through eastern Marion County. Later in geologic time, another smaller uplift occurred to the west of the Peninsular Arch, causing upwarping of lower Tertiary rocks. The axis of the latter, the Ocala Uplift, runs roughly parallel to and to the west of the Peninsular Arch. As the Ocala Uplift developed, tensional stresses caused the formation of fractures and possibly some normal faults in the Tertiary rocks (Miller, 1986). Faulkner (1973) mapped two conjugate sets of fractures in the study area that intersect at right angles, based on interpretation of aerial photographs, and reported that most of the numerous cave systems in Marion County are oriented along one or the other of the fracture systems. Fracture systems are apparent in the limestone near land surface and also at depth, based on interpretations of well logs (Phelps, 1994). Flow of carbon dioxide-rich recharge water through the fracture systems has resulted in the dissolution of rock and enlargement of fractures, which are the easiest flow paths for water. This process has been ongoing throughout the geologic past and continues to occur.

\section{Hydrogeologic Units and Hydraulic Properties}

In parts of the study area, the surficial aquifer system and the intermediate confining unit, which generally correspond to the post-Miocene and Miocene sediments, respectively (fig. 4), overlie the Floridan aquifer system. Where present (generally in the eastern part of Marion County or in outliers of the Hawthorn Group sediments in the western part of the County, fig. 5), these hydrogeologic units are thin and discontinuous. Because of its discontinuity, the surficial aquifer system is not a significant source of water in the study area.

The principal hydrogeologic unit of interest in the study area is the Upper Floridan aquifer, which generally is about $300 \mathrm{ft}$ thick in the study area (Sepúlveda, 2002, fig. 7) and includes the upper part of the Avon Park Formation, and where present, the Ocala Limestone. Porosity of the Upper Floridan aquifer in central Florida ranges from 15 to 40 percent, based on thin sections of five samples (Thayer and Miller, 1984). Because of the significant porosity of the limestone, flow in the Upper Floridan aquifer occurs in both rock matrix and the fracture or conduit systems, unlike the karst in older limestone in other geologic settings, where virtually all of the flow occurs in the conduits.

Transmissivity of the Upper Floridan aquifer depends on both primary (matrix) and secondary (conduit) porosity of the aquifer, and therefore, can vary widely. Three aquifer tests of the upper $100 \mathrm{ft}$ of the Upper Floridan aquifer yielded transmissivity ranging from 6,200 to 29,500 feet squared per day $\left(\mathrm{ft}^{2} / \mathrm{d}\right)$ (Tibbals, 1975). Transmissivity calculated from flow nets represents the full thickness of the aquifer and includes the effects of large solution channels - values ranged from 10,700 to $25,500,000 \mathrm{ft}^{2} / \mathrm{d}$, with an average value of $2,000,000 \mathrm{ft}^{2} / \mathrm{d}$ (Faulkner, 1973). Transmissivity for the Upper Floridan aquifer near Silver Springs from a calibrated model of ground-water flow was $12,000,000 \mathrm{ft}^{2} / \mathrm{d}$ (Sepúlveda, 2002). The large transmissivities result in rapid groundwater transit times; an average ground-water velocity of $0.8 \mathrm{ft}$ per minute at a gradient of about $1 \mathrm{ft}$ per mile was reported by Knochenmus (1967), based on a dye trace in the Silver Springs basin.

Beneath the Upper Floridan aquifer lie the middle semiconfining unit and the Lower Floridan aquifer. The middle semiconfining unit (MSCU) generally is about $100 \mathrm{ft}$ thick in the study area (Sepúlveda, 2002, figs. 7 and 8). It is composed of soft, fine-grained limestone and dolomitic limestone and occurs in the lower part of the Avon Park Formation (Miller, 1986). To the west of the study area, the MSCU is not present; in that area, the Upper and Lower Floridan aquifers are separated by the 


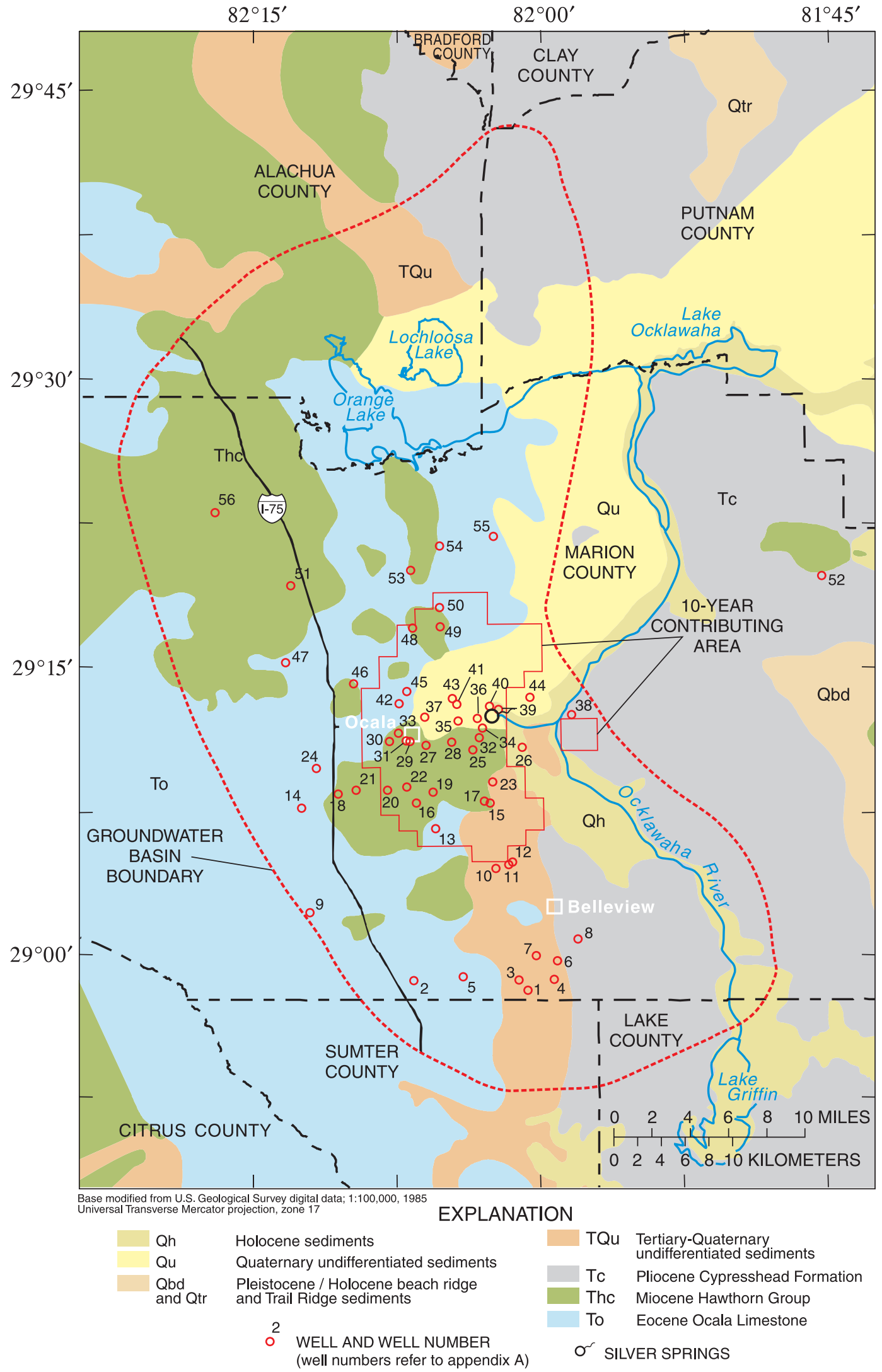

Figure 5. Generalized geology of the Silver Springs basin and well sampling locations (geology from Scott and others, 2001). 
middle confining unit (MCU), composed of gypsiferous dolomite and dolomitic limestone of considerably lower permeability than the MSCU (Sepúlveda, 2002; Miller, 1986). The horizontal facies change between the MSCU and the MCU is not well defined; however, lateral gradation between the two units could account for the increased sulfate concentrations with depth in ground-water samples reported by Faulkner (1973). Beneath the MSCU, at an altitude of about $400 \mathrm{ft}$ below NGVD 29, is the top of the Lower Floridan aquifer. Lithologic data for this aquifer in Marion County could not be located; few, if any, wells penetrate the aquifer in the County because adequate water supplies can be obtained from shallower formations.

All of the water that discharges from Silver Springs originates as recharge to the aquifer system in northcentral Florida. The average flow from the springs is about $800 \mathrm{ft}^{3} / \mathrm{s}$ or about 12 inches per year (in/yr) (Knowles, 1996). The discharge from wells in Marion County was estimated to be 71 million gallons per day (Mgal/d) or $110 \mathrm{ft}^{3} / \mathrm{s}$ (about 1.6 inches (in.)) in 2000 (U.S. Geological Survey, 2003a). This total discharge is supported by recharge rates ranging from about 10 to $20 \mathrm{in} / \mathrm{yr}$. Such recharge rates are in agreement with results from computer modeling (Sepúlveda, 2002). High rates of recharge occur in areas where the Upper Floridan aquifer is at or near land surface or covered by only a thin semiconfining layer (fig. 5). The aquifer is unconfined in areas where the Ocala Limestone crops out and poorly to moderately confined in areas where sediments of the Hawthorn Group occur at land surface. In the eastern part of the County, where Pliocene and younger sediments crop out, the Upper Floridan aquifer is confined. The area along the Ocklawaha River is a discharge area for the Upper Floridan aquifer.

\section{Ground-Water Flow}

Delineation of the ground-water basin, sometimes called the springshed, historically has been based on the potentiometric surface of the Upper Floridan aquifer by connecting points perpendicular to the potentiometric contours. The boundaries of the basin can change over time as the potentiometric surface fluctuates. For example, the area of the adjacent Rainbow Springs basin ranged from about $645 \mathrm{mi}^{2}$ in May 1994 to $772 \mathrm{mi}^{2}$ in September 1994 (Jones and others, 1996). Seasonal fluctuations of water levels in wells in the Silver Springs basin generally are about 3 to $5 \mathrm{ft}$, but the water level change in any particular well can vary depending on local rainfall and pumpage rates. In an area where the transmis- sivity is high, the hydraulic gradient is very flat and changes in the potentiometric surface may be small and the basin divide difficult to define. This is true of the flow divide between the Silver Springs and Rainbow Springs basins, along the western boundary of the Silver Springs basin. During this study, wells were added to the USGS potentiometric-surface network in May and September 2002 to better delineate the divide and help explain the effects of potentiometric fluctuations (figs. 6-7). These additions did not greatly improve delineation of the Silver Springs basin; it is likely that many more wells are needed to define the divide more accurately based on the potentiometric surface. Therefore, another method was used to delineate the ground-water basin for Silver Springs.

By adding particle tracking to a calibrated model of ground-water flow, the area contributing recharge to a spring for a particular range of travel times can be delineated (Shoemaker and others, 2003). The area contributing recharge to Silver Springs for water particles having travel times up to 500 years was computed with a flow model of peninsular Florida (Sepúlveda, 2002) and is shown in figures 6-7. The method used to perform the particle-tracking is described by Shoemaker and others (2003). The 500-year area encompasses about $570 \mathrm{mi}^{2}$ and extends farther south and not as far west or north as the contributing area based on the potentiometric surface. The area contributing recharge excludes discharge areas of the Upper Floridan aquifer along the Ocklawaha River that were included in the basin delineation based on the potentiometric surface. The time period for which this model was calibrated (August 1993-July 1994) was slightly drier than normal, as evidenced by the fact that discharge from Silver Springs was about $620 \mathrm{ft}^{3} / \mathrm{s}$ (compared to the average for the period of record (1932-2002), $\left.796 \mathrm{ft}^{3} / \mathrm{s}\right)$. The size and extent of the contributing area for other climatic conditions are likely to be different.

The area contributing recharge to Silver Springs for travel times up to 10 years also was computed for the same calibration period in order to allow an evaluation of water chemistry and land-use data on a time scale of interest to water managers. In general, models may indicate different contributing areas because of different hydrologic stresses, subsurface permeability properties, and boundary conditions used to calibrate each model (Shoemaker and others, 2003). In particular, travel times are inversely related to aquifer porosity values used in the models. Given the range of porosity in the study area, travel times could vary by an order of magnitude. 


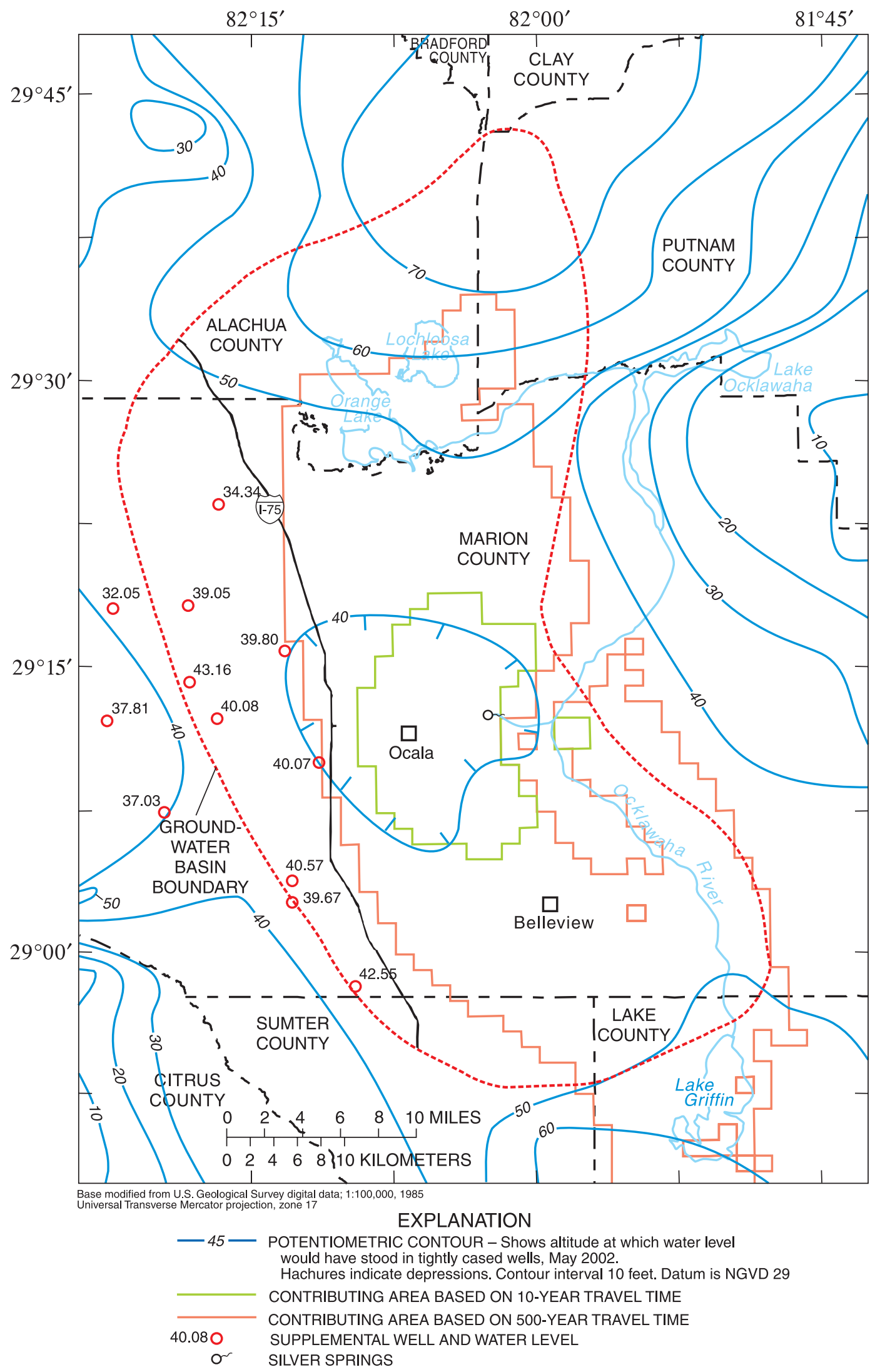

Figure 6. Potentiometric surface of the Upper Floridan aquifer in north-central Florida, May 2002, (modified from Kinnaman and Knowles, 2002) and areas contributing recharge to Silver Springs. 


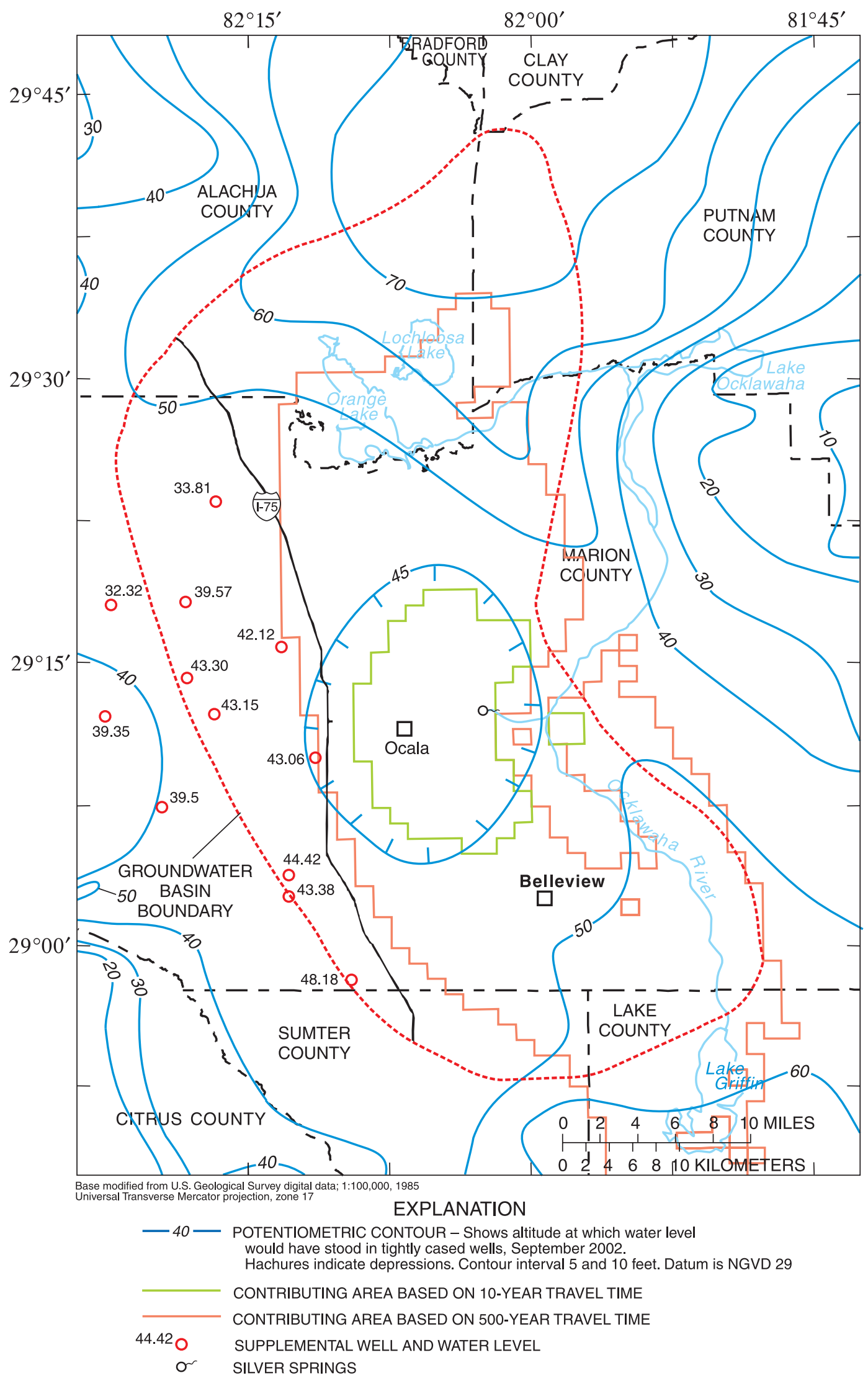

Figure 7. Potentiometric surface of the Upper Floridan aquifer in north-central Florida, September 2002, (modified from Kinnaman and Knowles, 2003) and areas contributing recharge to Silver Springs. 
The effect of this variation would be that the contributing area delineated would be for a somewhat longer travel time (perhaps 20 years rather than 10). A detailed review of existing ground-water flow models and, probably, refinements of those models would be needed to delineate a contributing area (springshed) that might be used by water managers for regulatory purposes.

The relative proportion of springflow recharged within particular contributing areas also is of interest for constructing geochemical mixing models. Based on the flow model for peninsular Florida (Sepúlveda, 2002), about 17 percent of the flow to Silver Springs is recharged within the 10-year contributing area and about 48 percent within the 30 -year contributing area (Shoemaker and others, 2003); these rates are $109 \mathrm{ft}^{3} / \mathrm{s}$ and $307 \mathrm{ft}^{3} / \mathrm{s}$, respectively, for the August 1993-July 1994 calibration period of the model.
A ground-water flow model also can be used to estimate a water budget for the study area. Sepúlveda (2002) determined that the time period August 1993-July 1994 represented steady-state conditions (negligible change in ground-water storage) in the Floridan aquifer system in peninsular Florida, based on evaluations of water levels. The flow model calibrated for that period was used to compute a water budget for the area contributing recharge to Silver Springs based on water travel times up to 500 years (fig. 8). From August 1993-July 1994, withdrawals from wells in the area totaled about 1.36 in. Recharge through drainage wells was about $0.12 \mathrm{in}$.; net recharge to the Upper Floridan aquifer was about 12.9 in. The net recharge rates exclude water lost to evapotranspiration, which was estimated to range from about 29 to $49 \mathrm{in} / \mathrm{yr}$ for the Silver Springs basin, based on data from 1965-94 (Knowles, 1996).

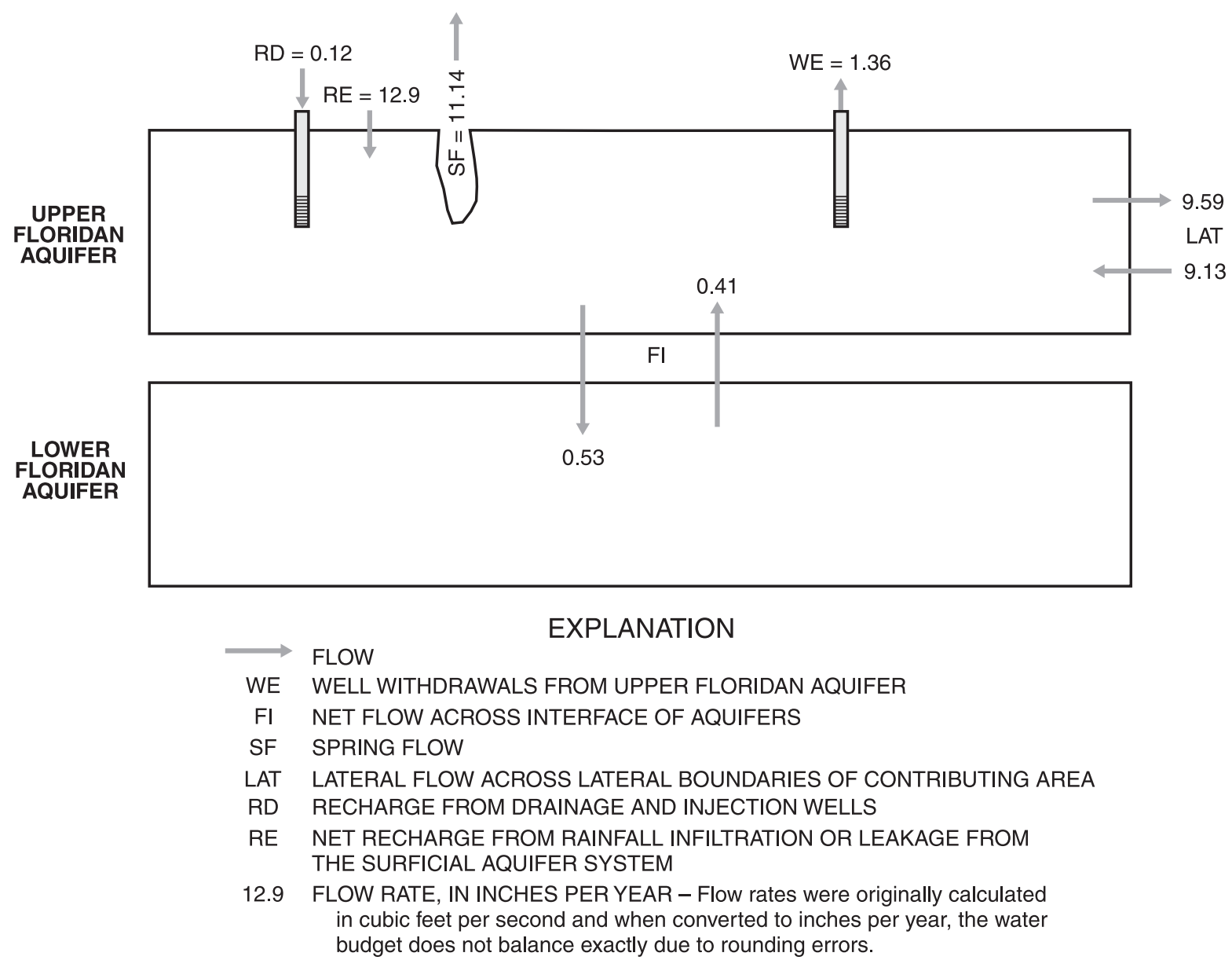

Figure 8. Simulated volumetric flow budget for the surficial aquifer system, Upper Floridan aquifer, and Lower Floridan aquifer, in areas contributing recharge to Silver Springs based on travel times up to 500 years, as simulated by the Peninsular Florida Model for the average August 1993 through July 1994 conditions (N. Sepúlveda, U.S. Geological Survey, written commun., 2003). 


\section{Silver Springs}

Silver Springs consists of several large springsincluding the Main Spring, also called Mammoth Spring; the Abyss, also known as Reception Hall; and the Blue Grotto - and numerous other smaller springs (sand boils) along the edges of the spring run. The springs form the headwaters of the Silver River, which flows eastward a few miles to the Ocklawaha River (fig. 1). Faulkner (1973) concluded that the locations of Silver Springs and the Ocklawaha River are related to the regional fracture systems in the rocks that compose the Floridan aquifer system. Faulkner suggested that structural lowering of the river valley and the area to the east of the river resulted in eastward flow of ground water in the limestone being blocked by lower permeability sediments of the Hawthorn Group (which were substantially eroded from areas west of the river). The ground water surfaced to form Silver Springs. The Main Spring contains a cave system of passages, some of which are interconnected, that likely are controlled by the regional fracture systems, based on a survey of about 2,260 ft of the system by divers (E. Hutcheson, private citizen, Ocala, Fla., written commun., 1993).

The flow system contributing water to Silver Springs is relatively shallow, based on hydrologic and waterchemistry data reported by Faulkner (1973). Faulkner concluded that hydrologic indicators such as the shape of the potentiometric surface and the results of aquifer tests and dewatering operations in the Barge Canal area suggested that the permeability of the Avon Park Formation was considerably lower than that of the Ocala Limestone. This probably indicates that most of the flow to the springs occurs in the Ocala Limestone rather than in deeper zones. In the study area, the Ocala Limestone generally is about $100 \mathrm{ft}$ thick, implying that most flow to Silver Springs occurs in the upper $100 \mathrm{ft}$ of the aquifer. Faulkner (1973) also discussed dissolved solids and sulfate concentration data and temperature data, all of which point to a shallow flow system. Based on these data, Faulkner (1973) estimated that about 86 percent of the water discharging from Silver Springs is from the upper part of the aquifer and about 14 percent is from the lower part or the Avon Park Formation.

\section{Land Use and Sources Of Nitrogen}

Land-use practices are generally thought to affect the chemical quality of ground water, although such effects may not be easy to quantify. This is true of nitrogen, which has natural and anthropogenic sources and is cycled continually in the environment by a complex set of chemical processes. The competing processes of (1) mineralization and immobilization and (2) nitrification and denitrification occur simultaneously (fig. 9). Some of these processes are mediated by microorganisms. Nitrate, which is highly soluble and mobile, is perhaps the most widespread contaminant of ground water (Hallberg and Keeney, 1993). It is an important plant nutrient and also is a component of all proteins. Atmospheric deposition (both by rainfall and dryfall) contributes nitrogen to an ecosystem. Most natural systems maintain a balance between the atmospheric and soil-plant systems (Hallberg and Keeney, 1993), although the amount of nitrogen added to the atmosphere by industrial processes has increased steadily since the 1940s (Stevenson, 1982). Other sources of nitrogen include fertilizer and animal and human wastes. The relative amounts of nitrogen from these sources and their potential contributions to $\mathrm{NO}_{3}{ }^{-}$in ground water will be discussed in the following section.

\section{Land Use, 1977 and 1995}

GIS coverages of land use for 1977 (U.S. Geological Survey, 1990) and 1995 (St. Johns River Water Management District, 1999) were analyzed to better understand the relations between land use and ground-water chemistry. Some difficulties were encountered, however, in relating water chemistry to land use and in comparing land-use data for different time periods. The land use that is indicated for a particular well site may be significantly different from adjacent land use. This can be especially problematic in a karstic area if a different land-use activity occurs upgradient from a sample site. Also, land-use categorization can be somewhat subjective and may not accurately reflect the actual activities at the site. For example, land use at one well sampled was indicated as pasture. After field verification, it was determined that the well is situated in a grassy field next to a mobile-home park that uses septic tanks for wastewater disposal. The site probably is more representative of urban residential than pasture land use. Finally, in an area that is undergoing rapid growth, such as Marion County, land-use coverages rapidly become out-of-date.

Comparing land-use coverages for 1977 and 1995 is difficult because of changes in the methods used for creating the coverages. In 1995, for example, the urban residential land category was divided into low, medium, and high density urban residential, depending on the number of dwellings per acre; but in 1977 these distinctions were not made. Subcategories for agricultural, range, and forest lands also were introduced in the 1995 coverage. Given 


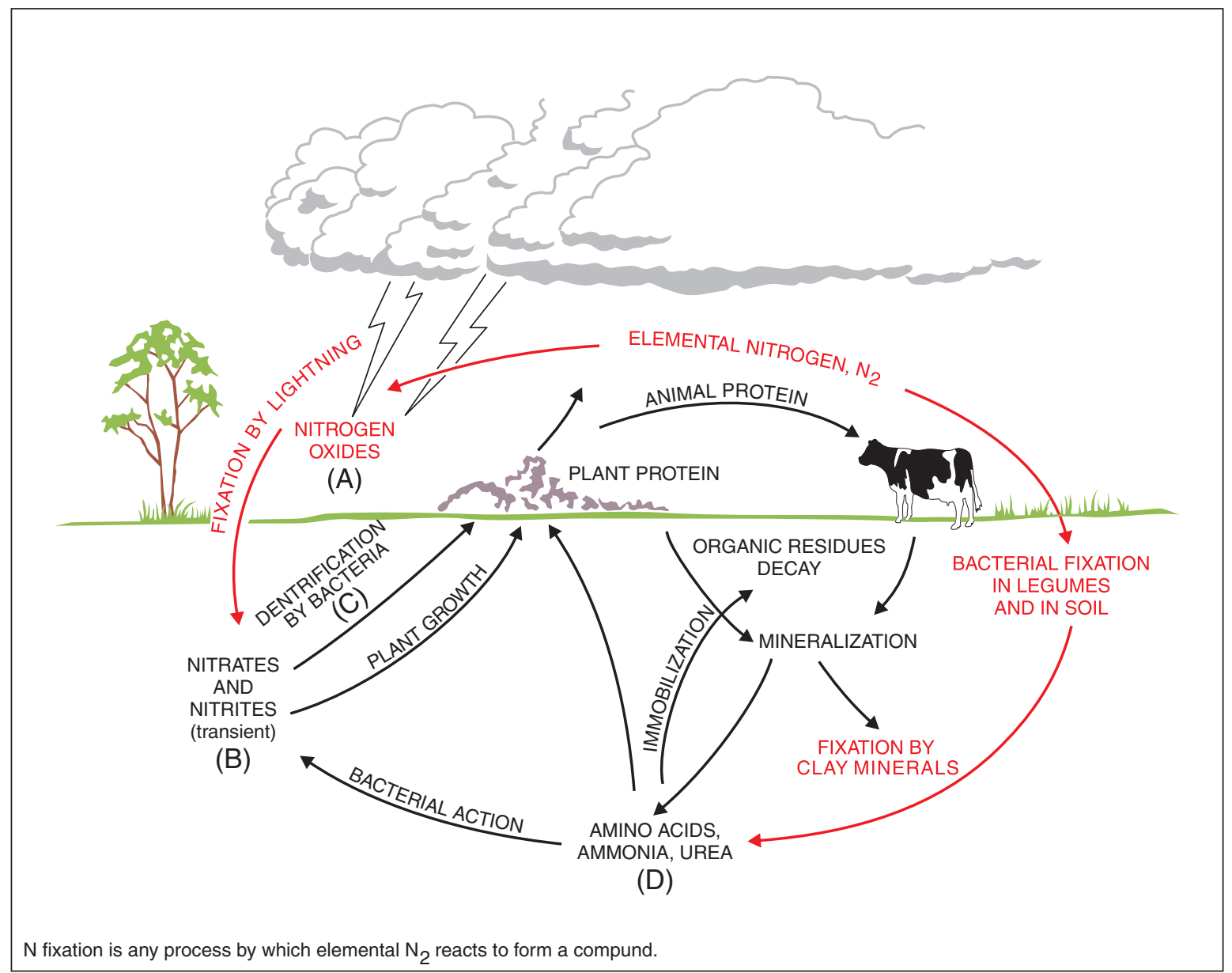

EXPLANATION
(A) $\begin{gathered}\mathrm{N}_{2}+\mathrm{O}_{2} \rightarrow 2 \mathrm{NO} \\ 2 \mathrm{NO}+\mathrm{O}_{2} \rightarrow 2 \mathrm{NO}_{2}\end{gathered}$
(B) $2 \mathrm{NO}_{2}^{-}+\mathrm{O}_{2} \rightarrow 2 \mathrm{NO}_{3}^{-}+$energy
(C) $\mathrm{NO}_{3}^{-} \rightarrow \mathrm{NO}_{2}^{-} \rightarrow \mathrm{NO} \rightarrow \mathrm{N}_{2} \mathrm{O} \rightarrow \mathrm{N}_{2}$
(D) $2 \mathrm{NH}_{4}^{+}+3 \mathrm{O}_{2} \rightarrow 2 \mathrm{NO}_{2}^{-}+2 \mathrm{H}_{2} \mathrm{O}+4 \mathrm{H}^{+}+$energy

Figure 9. Nitrogen cycle (modified from Keenan and Wood, 1971; Sumner and Bradner, 1996; and Pidwirny, 2003).

the discrepancies, perhaps the most useful comparison between the two time periods is the increase of urban land. Estimated urban residential land use in the springshed was about $38 \mathrm{mi}^{2}$ in 1977 and increased to about $164 \mathrm{mi}^{2}$ in 1995 (fig. 10).

\section{Sources of Nitrogen}

A nitrogen loading history for Marion County was estimated by compiling the inputs of nitrogen from various sources such as atmospheric deposition, fertilizers, and animal and human waste (fig. 11). These estimates are given in kilograms of total nitrogen, although not all of the nitrogen was in the form of nitrate. Also, the loads (except for atmospheric deposition) are for the entire County and were not apportioned between the Silver Springs basin and the other major springshed in Marion County, the Rainbow Springs basin. About $260 \mathrm{mi}^{2}$ of the Rainbow Springs basin lie in Marion County, compared to about $790 \mathrm{mi}^{2}$ of the Silver Springs basin.

Atmospheric deposition of nitrogen was estimated from data collected at a National Atmospheric Monitoring Deposition Program (NADP) (2002) site in Bradford Forest, Bradford County (fig. 1). Some of the nitrogen in the atmosphere is naturally occurring but atmospheric deposition of nitrogen probably has increased tenfold since the late 19th century (Howarth and Rielinger, 2004), 


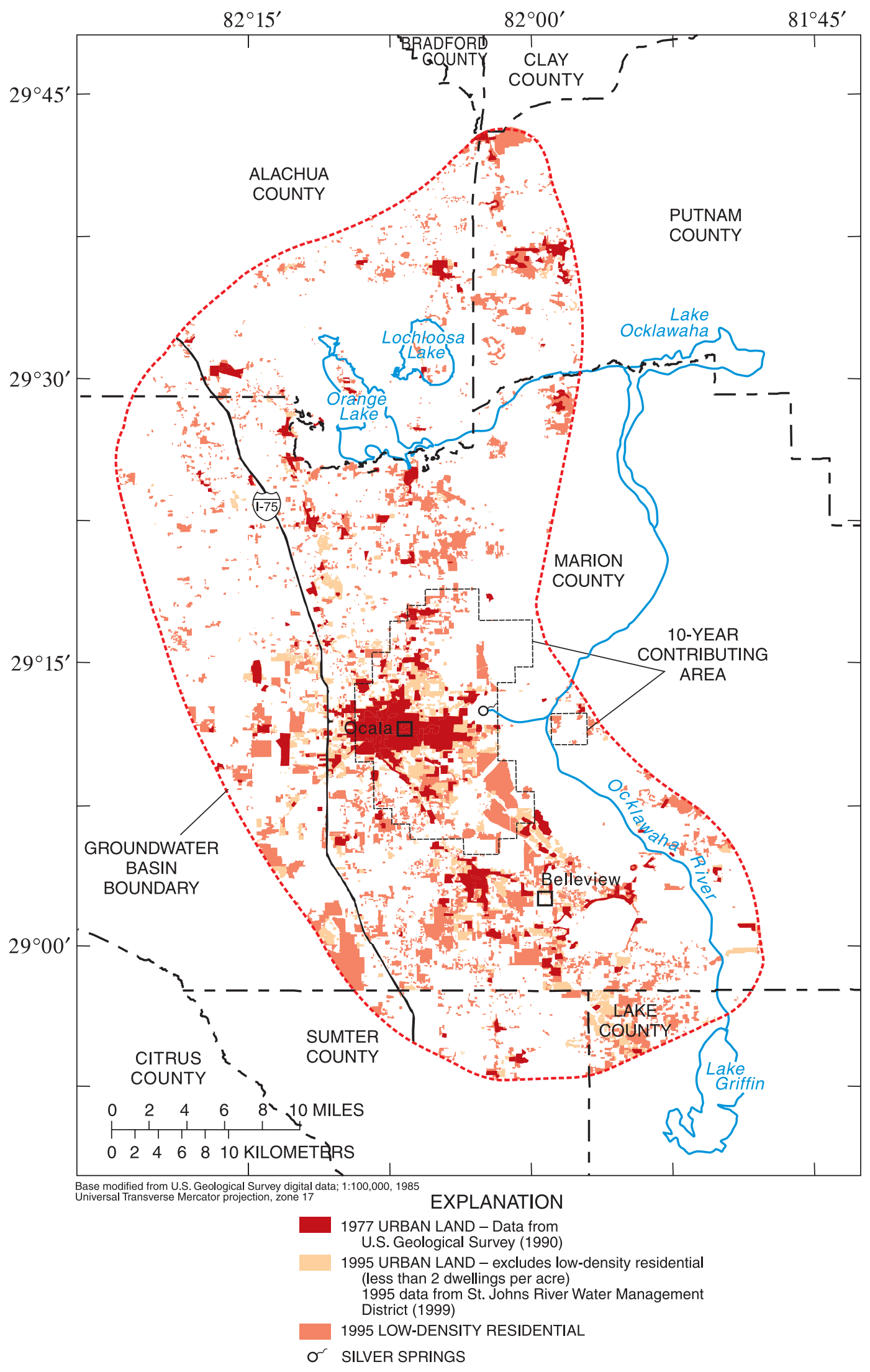

Figure 10. Urban residential land use in 1977 overlain on 1995 urban residential. 


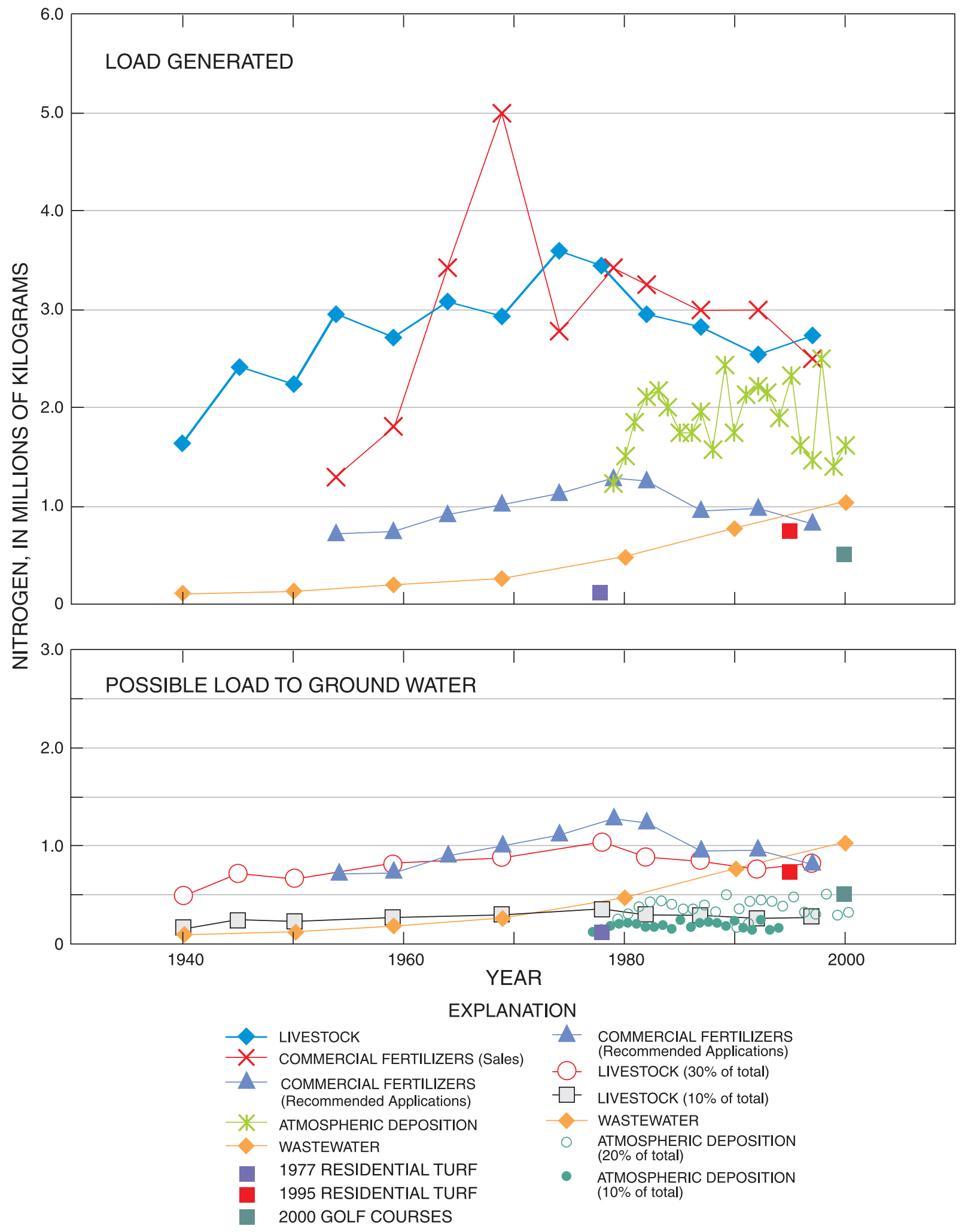

Figure 11. Estimated annual nitrogen inputs for Marion County, Florida, 1940-2000. 
mostly from the burning of fossil fuels and from vehicle emissions. The NADP station began operating in 1978, although data for that year are not included because there is only a partial record. The nitrogen load was calculated based on the methodology described by Katz and others (1999) and assuming that the basin size was $1,200 \mathrm{mi}^{2}$. The loading from atmospheric nitrogen fluctuates with time but does not show a trend. The amount of nitrogen from atmospheric deposition that reaches ground water is largely unknown. At a study site in the United Kingdom, it was estimated about 11 to 18 percent of the total nitrogen leached to the ground water came from atmospheric deposition (Harris, 2004). In many forested regions, only 10 to 20 percent of atmospherically deposited nitrogen is exported downstream in the surface watershed (Howarth and Rielinger, 2004). To reflect the uncertainty in loading from atmospheric deposition, the relative loads-assuming that 10 and 20 percent of the atmospheric nitrogen reaches the ground water-also are shown in figure 11 .

Nitrogen loads from fertilizers can be difficult to estimate because data are compiled on a county-wide basis. Fertilizer sales data, compiled annually by the Florida Department of Agriculture and Consumer Services (FDACS), tend to overestimate loads because those data include fertilizer sold in Marion County by large distributors but transported to other counties for use. The amount of each type of fertilizer material sold was multiplied by the percentage of $\mathrm{N}$ it contained and summed to obtain annual estimates of $\mathrm{N}$ from fertilizers sold in the County (Katz and others, 1999). Another method for estimating nitrogen loads is to multiply recommended fertilizer application rates by the estimated number of acres of various crops from agricultural census data. The number of acres cultivated in various crops was estimated from the Florida Agricultural Census (U.S. Department of Agriculture, 1997; U.S. Department of Agriculture, unpublished data) and multiplied by the respective recommended application rate for various crops compiled by the Florida Institute of Food and Agricultural Sciences (Jones and others, 1974; Kidder and others, 1998). Implicit in this calculation is the assumption that growers are applying fertilizer at the recommended rate. Fertilizer sales and recommended application information begin in the 1950 s. Low $\mathrm{N}$ prices in the 1940s and 1950s and the desire to improve citrus crop yields resulted in high application rates during that period. Higher prices since the early 1970s influenced growers to reduce the rates of $\mathrm{N}$ applications (Stricker and Muraro, 1981). Recommended fertilizer use estimates also are county-wide so it was not possible to determine what percentage of the fertilizer applied was used in Marion County but outside the Silver Springs basin. The actual nitrogen load from agriculture in the springshed probably is bracketed by the sales and recommended application rate estimates.

In addition to agricultural uses, fertilizers also are applied to residential turfgrass and to golf courses. Estimating such loads may be difficult because some of the fertilizer already may be accounted for in the county-wide sales data. For comparison with other estimates of fertilizer use, the golf course load for 2000 was estimated based on about 20 golf courses in the study area that year. Based on an approximate application rate of 28 tons $(25,000$ kilograms) $(\mathrm{kg})$ per year of $\mathrm{N}$ per golf course (Jones and others, 1996), the total $\mathrm{N}$ load was about $500,000 \mathrm{~kg}$ (fig. 11). Residential fertilizer use in the entire $1,200 \mathrm{mi}^{2}$ study area for 1977 and 1995 (the years for which land-use coverage data are available) was calculated for comparison with other N load estimates. In 1995, urban residential land was subdivided into low, medium, and high density, whereas in 1977 all urban residential land was combined. Percentages of low, medium, and high density were assumed to be the same in 1977 as in 1995, which may not be the case. For example, in 1995 about 91 percent of the urban residential land was low density, about 3 percent medium density, and about 6 percent high density, so the same percentages were assumed to be true in 1977. Based on a review of aerial photographs in the Rainbow Springs basin, Jones and others (1996) determined that the approximate percentages of property covered by turf are 34 percent for high density, 66 percent for medium density, and 17 percent for low density residential. Jones and others (1996) also estimated that about 2 pounds (about $0.9 \mathrm{~kg}$ ) per year of $\mathrm{N}$ was applied per $1,000 \mathrm{ft}^{2}(0.023$ acres $)$ of turfgrass. Applying the same method for residential land in the Silver Springs basin results in calculated N loads of about 114,000 kg for 1977 and 727,000 kg for 1995 (fig. 11).

Estimates of $\mathrm{N}$ loads from livestock manure were calculated for 1940-2000 based on animal population data from the U.S. Department of Agriculture (1997; U.S. Department of Agriculture, unpublished data), including beef and dairy cattle, calves, hogs and pigs, sheep, horses, turkeys, and pullets and chickens. Nitrogen produced by each species was calculated based on a methodology described by the U.S. Geological Survey (1998) that calculates a load based on body weight and number of animals. As a result of various handling methods, the fraction of the total $\mathrm{N}$ load generated by livestock that reaches the ground water can vary widely. Estimates as low as 10 to 30 percent are not unreasonable (Katz and others, 1999); the relative contributions based on those estimates also are shown in figure 11. 
Another source of nitrogen is human wastes, either from municipal waste treatment systems or from OSDS, commonly called septic tanks. Estimates of the nitrogen output from such systems and the amount of nitrogen removed from the systems as nitrogen gas $\left(\mathrm{N}_{2}\right)$ due to denitrification in the soil zone can vary widely; therefore, calculating the loads is complex. An attenuation by denitrification of 20 percent was estimated by Otis and others (1993); rates as high as 80 percent were reported by Horsley and others (1996).

Based on housing data from the U.S. Census Bureau (2002), approximately 36 percent of the dwelling units in Marion County use public sewers for waste disposal; the remaining 64 percent use OSDS. No additional data on the number or distribution of OSDS in the County were available. Also, there are no data from municipal wastewater treatment facilities prior to 1990 and $\mathrm{N}$ removal is not part of the treatment process. Therefore, the $\mathrm{N}$ load from all sources of wastewater was estimated on a per capita basis. The total population of Marion County was multiplied by a total $\mathrm{N}$ load of 4.09 kilograms per year (kg/yr) (Otis and others, 1993; Katz and others, 1999) (table 1). As with the load from fertilizers, it was not possible to determine the proportion of the wastewater load actually generated within the Silver Springs springshed. The loads from agricultural practices generally are decreasing (1975-2000), but loading from wastewater is increasing as the population increases (fig. 11).

\section{Land Use in the 10-Year Contributing Area}

Based on the conclusion by Faulkner (1973) that most of the flow to Silver Springs is relatively shallow (and, therefore, rapid), the area contributing recharge to the spring within a 10-year travel time (figs. 5 and 12) was delineated by using particle tracking and a computer model of ground-water flow in peninsular Florida (Sepúlveda, 2002; N. Sepúlveda, U.S. Geological Survey, written commun., 2003). The methodology used to perform the particle-tracking is described by Shoemaker and others (2003). The presence of a smaller, discontinuous area to the east of the Ocklawaha River results because although the area along the Ocklawaha River is a discharge area for the Upper Floridan aquifer, recharge that enters the Upper Floridan aquifer east of the river (probably by upward movement from the Lower Floridan aquifer) does discharge from Silver Springs (Shoemaker and others, 2003). The blocky (rather than smooth) outline of the contributing area (fig. 12) is the result of the coarseness of the finite-difference grid used in the model. Land use within the 10-year contributing area was examined (figs.
10 and 12). An increase in urban areas is evident. Also, some land classified as agricultural in 1977 was classified as rangeland in 1995; some areas classified as forest in 1977 were classified as recreation/open land in 1995.

Nitrogen loads from wastewater and for lawn fertilization were estimated for the 10-year contributing area because the area is mostly urban and these are the main sources of $\mathrm{N}$. The wastewater load (regardless of whether disposed through a municipal system or by OSDS) was estimated based on the total population of the 10-year contributing area in 1990, calculated from census data (U.S. Census Bureau, 2002). The total population of that area $(97,330)$ was multiplied by an estimated per capita $\mathrm{N}$ load of $4.09 \mathrm{~kg} / \mathrm{yr}$ (Otis and others, 1993), resulting in a load estimate of about $398,000 \mathrm{~kg} / \mathrm{yr}$. The load from residential turf fertilization was estimated by using the 1995 land-use coverage data and the same assumptions for application rates as described above from Jones and others (1996). The total annual load for lawn fertilization in the 10 -year contributing area was estimated to be $770 \mathrm{~kg}$, indicating that wastewater potentially is a more significant source of nitrogen than fertilizer within the 10-year contributing area.

\section{Chemistry of Ground and Spring Water}

During 2001-2002, water samples were collected from 56 wells in the study area and from three springs of the Silver Springs group. Data for field measurements, major ions, and nutrients are shown in appendix A. Wells were selected to be representative of the major land-use types in the study area based on 1995 land-use data. Land use at each sampled well was determined using GIS techniques and confirmed by field observations. Also, some wells were located in the area where the Upper Floridan aquifer is confined and others in areas where the aquifer is unconfined. Depth information was not available for all wells sampled; however, it is likely that all wells are representative of the Upper Floridan aquifer because for economic reasons, wells generally are completed in the shallowest productive unit.

\section{Major lons and Trace Constituents}

Calcium, sulfate, and chloride are constituents that generally are of importance in ground water because they can affect the levels of treatment needed for water supply. In the Silver Springs basin, calcium concentrations in water from the 56 wells sampled during this study ranged from 24 to $176 \mathrm{mg} / \mathrm{L}$, with a median value of $71.5 \mathrm{mg} / \mathrm{L}$ (fig. 13). 

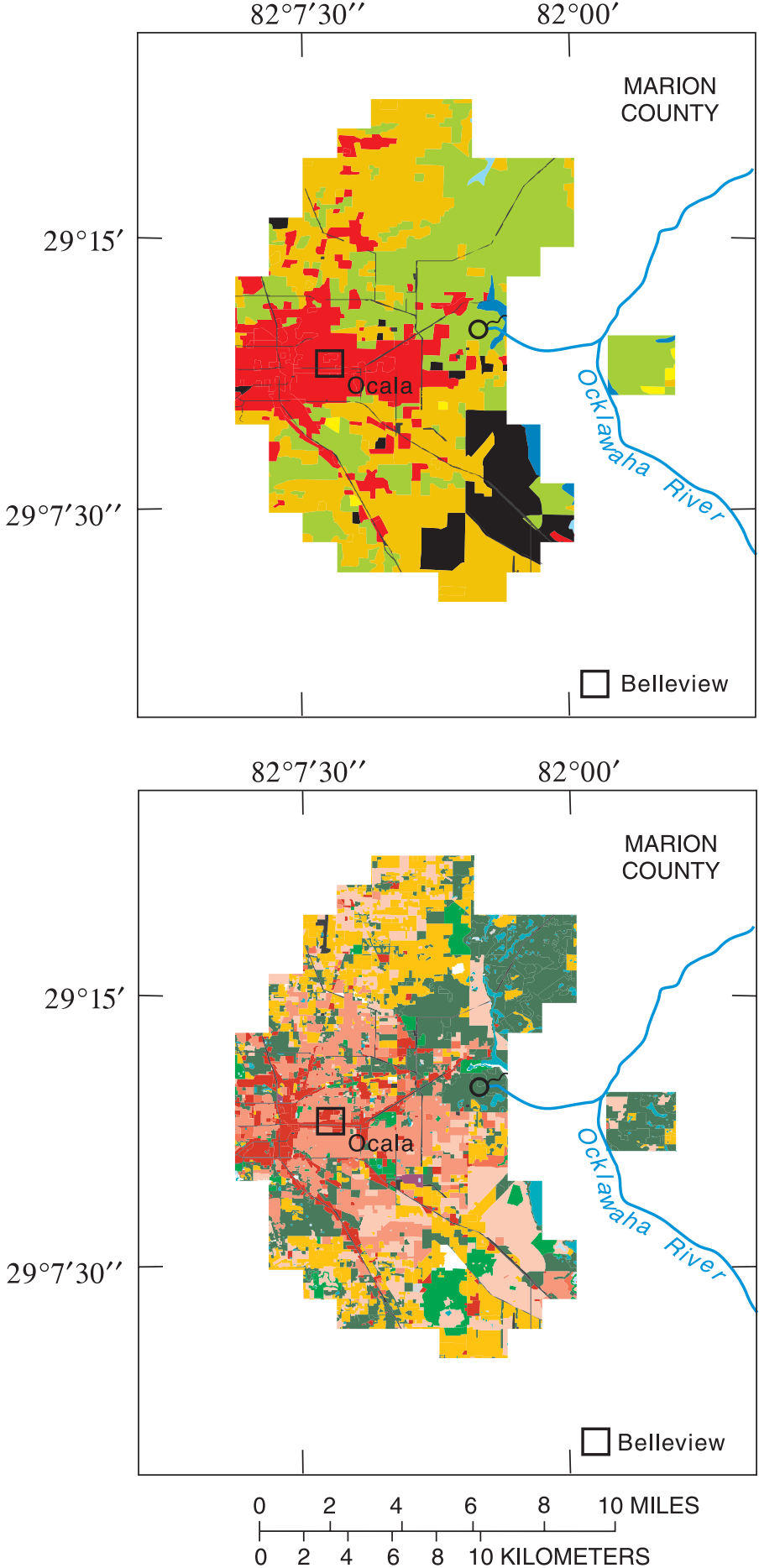

\section{EXPLANATION}

1977 LAND USE - Data from U.S. Geological Survey (1990)

URBAN

AGRICULTURAL

RANGELAND

FOREST

WATER

WETLAND

BARREN OR TRANSITIONAL

1995 LAND USE - Data from St. Johns River Water Management District (1999)

LOW DENSITY RESIDENTIAL MEDIUM DENSITY RESIDENTIAL

HIGH DENSITY RESIDENTIAL

COMMERCIAL / INDUSTRIAL

RECREATION / OPEN LAND

RANGELAND

PASTURE

LIVESTOCK OPERATIONS

HORSE FARMS

HORTICULTURAL OPERATIONS

SILVICULTURAL OPERATIONS

UPLAND FORESTS

WATER

WETLANDS

BARREN LAND

TRANSPORTATION COMMUNICATIONS, UTILITIES

SEWAGE TREATMENT

or SILVER SPRINGS

Figure 12. 1977 and 1995 land use in the area contributing recharge to Silver Springs based on travel times up to 10 years. 

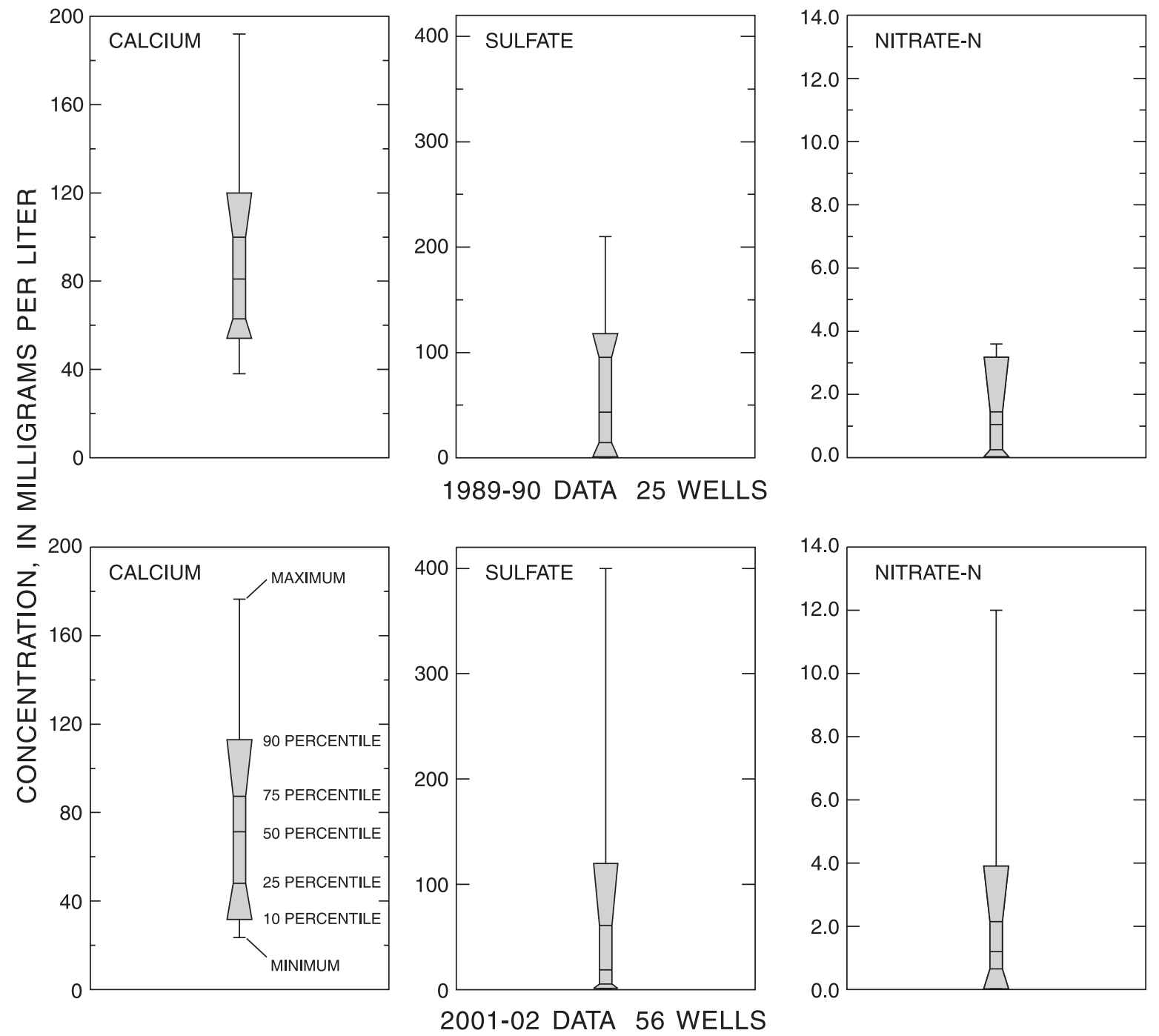

Figure 13. Ranges of calcium, sulfate, and nitrate- $\mathrm{N}$ concentrations for water samples collected in 1989-90 and during this study, 2001-02.

Sulfate values ranged from 0.6 to $400 \mathrm{mg} / \mathrm{L}$, with a median of $20 \mathrm{mg} / \mathrm{L}$. These are typical ranges for water withdrawn from the carbonate rocks of the Upper Floridan aquifer. Sulfate concentrations can range widely because of the presence or absence of sulfate minerals such as gypsum in the aquifer (Sacks, 1996). Sulfate concentrations generally increase with depth in the Upper Floridan aquifer (Faulkner, 1973). The maximum values of both calcium and sulfate occurred in the same well (9), which is one of the deepest wells sampled $(210 \mathrm{ft})$. On the other hand, well 4 was $220 \mathrm{ft}$ deep but had a sulfate concentration of only $13 \mathrm{mg} / \mathrm{L}$ and a calcium concentration of $24 \mathrm{mg} / \mathrm{L}$ (app. A). The highest chloride concentration measured was $230 \mathrm{mg} / \mathrm{L}$ in well 48 , which also had a sodium concentration of $140 \mathrm{mg} / \mathrm{L}$. This sample, however, may have been affected by backflow from a water softener. The next highest chloride concentration measured, $88 \mathrm{mg} / \mathrm{L}$, was in water from a well (11) near a municipal wastewater land application facility (app. A).

The data collected during this study were compared to data from a previous study (Phelps, 1994) collected in 1989-90 also using standard USGS protocols (Wood, 1976). During that study, samples were collected from 25 wells without consideration to land use at the site (Phelps, 1994). Six wells (18, 29, 30, 33, 35, and 41) were sampled during both study periods. The median calcium value for the 1989-90 data was $82 \mathrm{mg} / \mathrm{L}$, compared to a median of $72 \mathrm{mg} / \mathrm{L}$ for the present study. There was a greater variation in sulfate concentrations during the present study. The median for the 1989-90 samples was $45 \mathrm{mg} / \mathrm{L}$ and the 

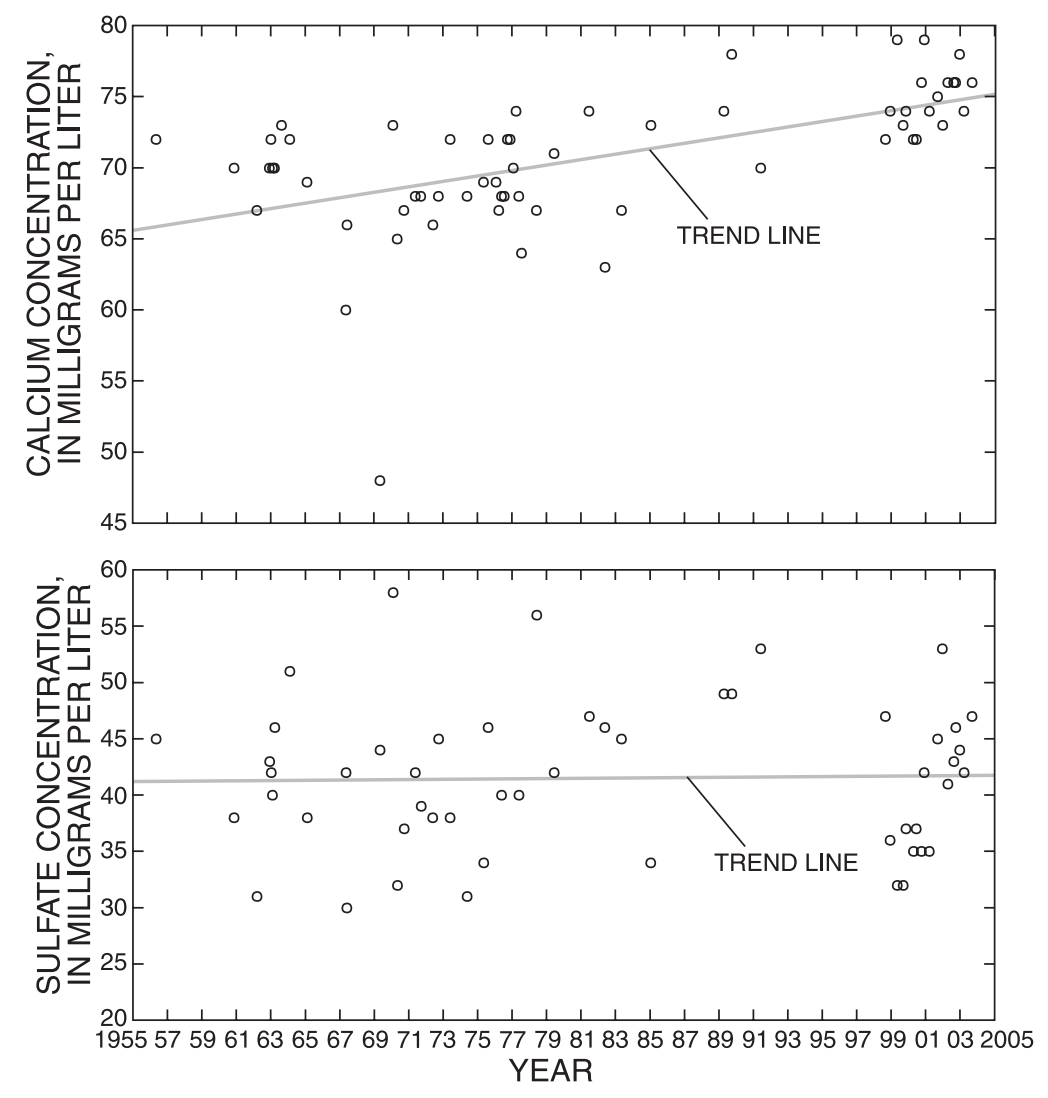

Figure 14. Calcium and sulfate concentrations in water from the Silver Springs Main Spring, 1955-2003.

maximum value was about $220 \mathrm{mg} / \mathrm{L}$; whereas, the median for the 2001-02 data was lower, only about $20 \mathrm{mg} / \mathrm{L}$, but the maximum value was much greater, about $400 \mathrm{mg} / \mathrm{L}$ (fig. 13). This difference in the maximum value probably is because the samples from the present study may have included more deep wells, and thus, represent a wider range of hydrogeologic conditions than the wells sampled during the previous study.

Calcium and sulfate concentrations have been measured by the USGS in water from the Main Spring of Silver Springs since 1956. Calcium concentrations range from 48 to $78 \mathrm{mg} / \mathrm{L}$, and sulfate concentrations range from about 30 to $58 \mathrm{mg} / \mathrm{L}$ (fig. 14). Calcium concentration shows a slight increasing trend (determined by regression analysis), although the correlation is relatively weak $\left(r^{2}=0.31\right)$. No trend is apparent in sulfate concentration.

The trace constituents boron (B) and manganese $(\mathrm{Mn})$ were analyzed in ground-water samples because both are contained in synthetic fertilizers and B also is found in some laundry products. Igneous and metamorphic rocks are important natural sources of these elements
(Hem, 1985). In Florida, however, such rocks are present only at great depth below the aquifer system. Therefore, the presence of $\mathrm{B}$ and $\mathrm{Mn}$ in ground water probably indicates the effects of either fertilizer use or wastewater.

Concentrations of B ranged from 9 to 74 micrograms per liter $(\mu \mathrm{g} / \mathrm{L})$, with the highest concentration occurring in water from a monitor well located in a wastewater sprayfield (well 11, fig. 5 and app. A). The next highest concentration $(51 \mu \mathrm{g} / \mathrm{L})$ was in water from well 8 in an undeveloped area of a park, which was not likely to have been impacted by either wastewater or current fertilizer use. However, the site is shown as a citrus grove on the USGS 7.5-minute Lake Weir topographic map (dated 1970 and photorevised in 1980); therefore, the high B concentration at well 8 may result from historic fertilizer applications. Concentrations of $\mathrm{Mn}$ in ground-water samples ranged from less than the detection limit of 1.0 to $530 \mu \mathrm{g} / \mathrm{L}$. Water from a well in an urban commercial area (well 35, fig. 5 and app. A) had the highest concentration of Mn. This may be the result of fertilizer applications. 
A consistent relation does not seem to exist between the concentrations of $\mathrm{B}$ and $\mathrm{Mn}$ in ground-water samples. For example, at well 8 , where the B concentration was $51 \mu \mathrm{g} / \mathrm{L}$ (the second highest value measured), the $\mathrm{Mn}$ concentration was $16 \mu \mathrm{g} / \mathrm{L}$ (four other wells had higher Mn concentrations). Water from well 35, which had the highest Mn concentration, $530 \mu \mathrm{g} / \mathrm{L}$, had a B concentration of only $20 \mu \mathrm{g} / \mathrm{L}$. Likewise, there was no consistent relation between $\mathrm{B}$ and $\mathrm{Mn}$ concentrations and land use. For example, land use at well 44 is low-density residential and concentrations of $\mathrm{B}$ and $\mathrm{Mn}$ in the water are 40 and $60 \mu \mathrm{g} / \mathrm{L}$, respectively; whereas the concentrations of both constituents were significantly lower in water from other wells (wells 4, 24, and 50; fig. 5 and app. A) with similar land use. Differences in past fertilizer usage, as well as the presence or absence of an OSDS, could account for the apparent lack of a relation to land use.

\section{Dissolved Oxygen and Nutrients}

Dissolved oxygen (DO) measured in the field can be an indicator of recently recharged ground water because there generally are no sources of oxygen in the aquifer and the longer the water is contained in an aquifer, the lower the DO becomes (Katz and others, 1999). DO concentrations ranged from $0.1 \mathrm{mg} / \mathrm{L}$ at well 38 to 8.3 $\mathrm{mg} / \mathrm{L}$ at well 5 (fig. 15). The water from well 38 (fig. 5) had a slight hydrogen sulfide odor, indicating that it probably came from relatively deep in the aquifer. The well is in an area where the Upper Floridan aquifer is confined (fig. 15), so the low DO is expected. DO generally is high in unconfined areas of the Upper Floridan aquifer, but high values also occur in confined areas, such as in the southern part of the basin. This could be due to local variations in aquifer confinement that are not apparent on a regional scale. In general, areas with high levels of DO in the ground water could be more vulnerable to rapid infiltration of $\mathrm{N}$ loads from the land surface.

Dissolved oxygen in water discharging from the Main Spring of Silver Springs ranged from 1.3 to $2.8 \mathrm{mg} / \mathrm{L}$ during the study and the concentration was slightly higher in water from the Abyss and the Blue Grotto (app. A).

A total of 66 DO measurements by the USGS in the Main Spring from 1977 to 2002 ranged from 1.3 to $6.8 \mathrm{mg} / \mathrm{L}$, with a median of $2.3 \mathrm{mg} / \mathrm{L}$. In general, DO from the Main Spring increases with increasing discharge.

Nitrogen occurs in water in several forms: $\mathrm{NO}_{2}{ }^{-}$, $\mathrm{NO}_{3}{ }^{-}$, and ammonium $\left(\mathrm{NH}_{4}^{+}\right)(\mathrm{Hem}, 1985)$. Ammonium ions are strongly adsorbed on mineral surfaces and nitrite is unstable in aerated water. Nitrate is mobile in water and is stable in ground water under some conditions.
Laboratory analyses usually report a combined value for $\mathrm{NO}_{2}^{-}$-plus- $\mathrm{NO}_{3}^{-}$as $\mathrm{N}$. Values for $\mathrm{NO}_{2}^{-}$are determined as well (and often are less than the detection limit of 0.02 $\mathrm{mg} / \mathrm{L}$ ) so the concentration of $\mathrm{NO}_{3}^{-}$(nitrate-N) is approximately equal to the concentration of $\mathrm{NO}_{2}{ }^{-}$-plus $-\mathrm{NO}_{3}{ }^{-}$.

Values of nitrate- $\mathrm{N}$ for the study area ranged from less than the detection limit of 0.02 to $12 \mathrm{mg} / \mathrm{L}$ as $\mathrm{N}$, with a median value of 1.2 (fig. 13). The areal distribution of nitrate-N (fig. 16) shows that, similar to DO, concentrations vary and do not seem to be related to the degree of aquifer confinement as shown by the regional delineation of geologic units. Also, although water samples with higher nitrate-N concentrations generally had higher DO values, there does not seem to be a predictive relation between the two constituents (fig. 17). The grouping of nitrate values in figure 16 is based on ranges described by Madison and Brunett (1985) as follows:

\begin{tabular}{l|l} 
Less than $0.2 \mathrm{mg} / \mathrm{L}$ & $\begin{array}{c}\text { Assumed to represent background } \\
\text { conditions. } \\
\text { Transitional; concentrations may or may } \\
\text { not represent influence from human } \\
\text { activities. } \\
\text { 0.2-3.0 mg/L }\end{array}$ \\
$\begin{array}{l}\text { May indicate elevated concentrations } \\
\text { resulting from human activities. } \\
\text { Exceeds Maximum Contaminant Level }\end{array}$ \\
More than $10 \mathrm{mg} / \mathrm{L}$ & $\begin{array}{l}\text { (MCL) for nitrate-N (U.S. Environmental } \\
\text { Protection Agency, 2003). }\end{array}$
\end{tabular}

One well sampled (well 49) exceeded the MCL for nitrate-N.

Concentrations of phosphorus (P), another nutrient, were analyzed as total phosphorus and total orthophosphate. Phosphorus is not as mobile as nitrogen and because of the ability of phosphate to sorb onto metal oxides and carbonate minerals, concentrations in natural water greater than a few hundredths or tenths of a milligram per lieter are rare (Hem, 1985). Concentrations of total orthophosphate in water from the 56 wells sampled ranged from 0.01 to $0.89 \mathrm{mg} / \mathrm{L}$, with a median value of $0.03 \mathrm{mg} / \mathrm{L}$; total $\mathrm{P}$ ranged from 0.02 to $2.7 \mathrm{mg} / \mathrm{L}$ with a median of $0.04 \mathrm{mg} / \mathrm{L}$ (fig. 18). Hawthorn Group sediments can contain phosphate-bearing minerals such as apatite, but because those minerals have a low solubility and the Hawthorn sediments are relatively thin and discontinuous in the study area, they probably are not a major source of phosphate in ground water. Hem (1985) reported that $\mathrm{P}$ is present in animal metabolic waste and that domestic and industrial sewage effluents probably are sources of $\mathrm{P}$ in surface water. In the study area, where wastewater is disposed by land application instead of to surface water, effluent could thus be a source of $\mathrm{P}$ to the ground water. 


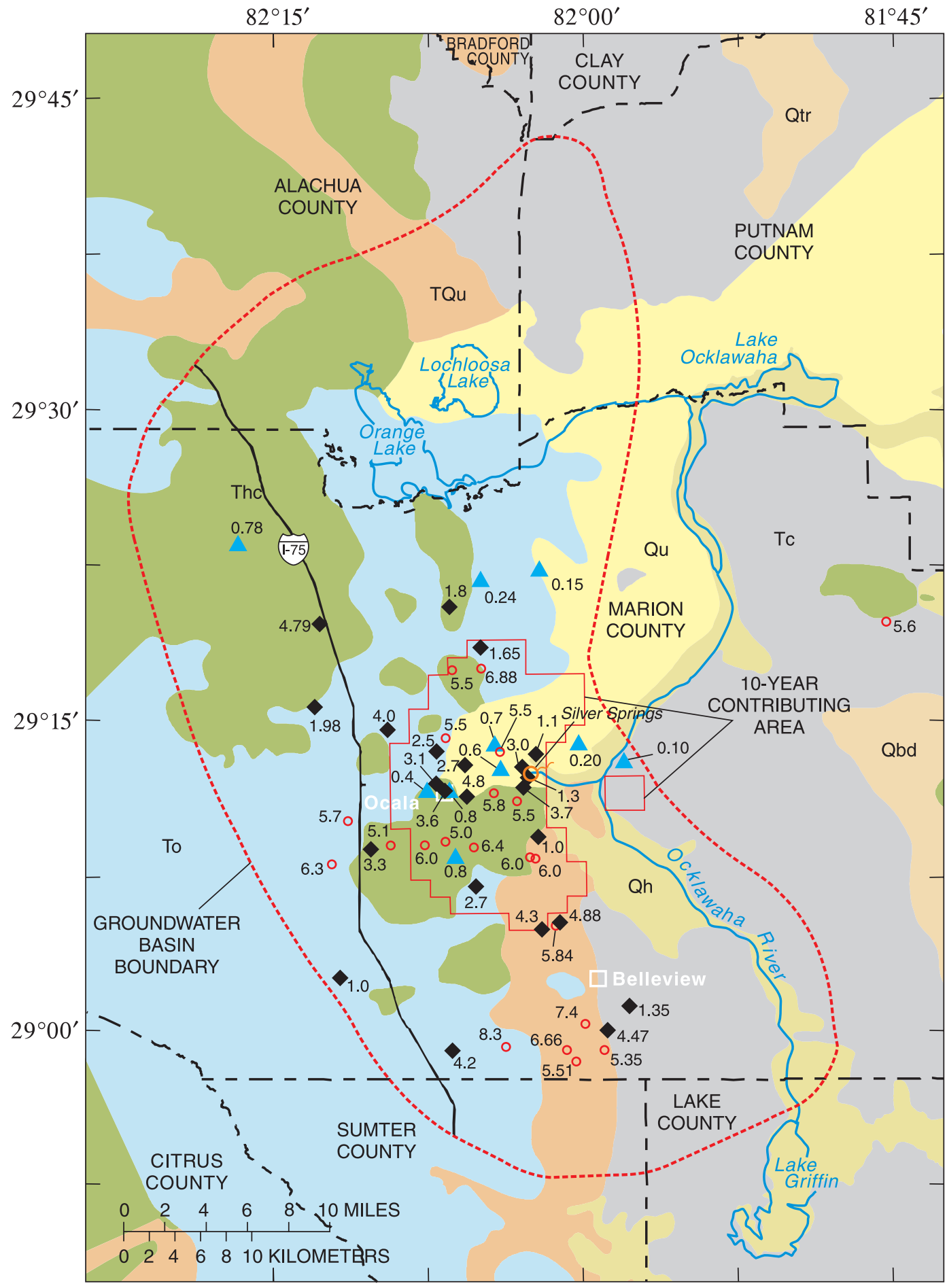

$$
\begin{aligned}
& \text { Base modified from U.S. Geological Survey digital data; 1:100,000, } 1985 \\
& \text { Universal Transverse Mercator projection, zone } 17 \text { EXPANATION }
\end{aligned}
$$

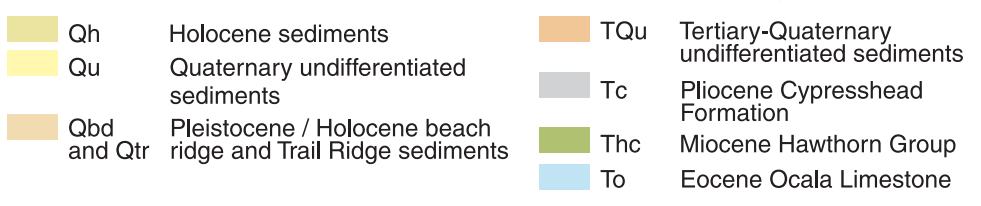

$$
\begin{aligned}
& 0.24 \triangle<1 \\
& 1.35 \\
& 5.350 \geq 5
\end{aligned}
$$

Figure 15. Dissolved oxygen concentrations in water from the Upper Floridan aquifer, Silver Springs basin. 


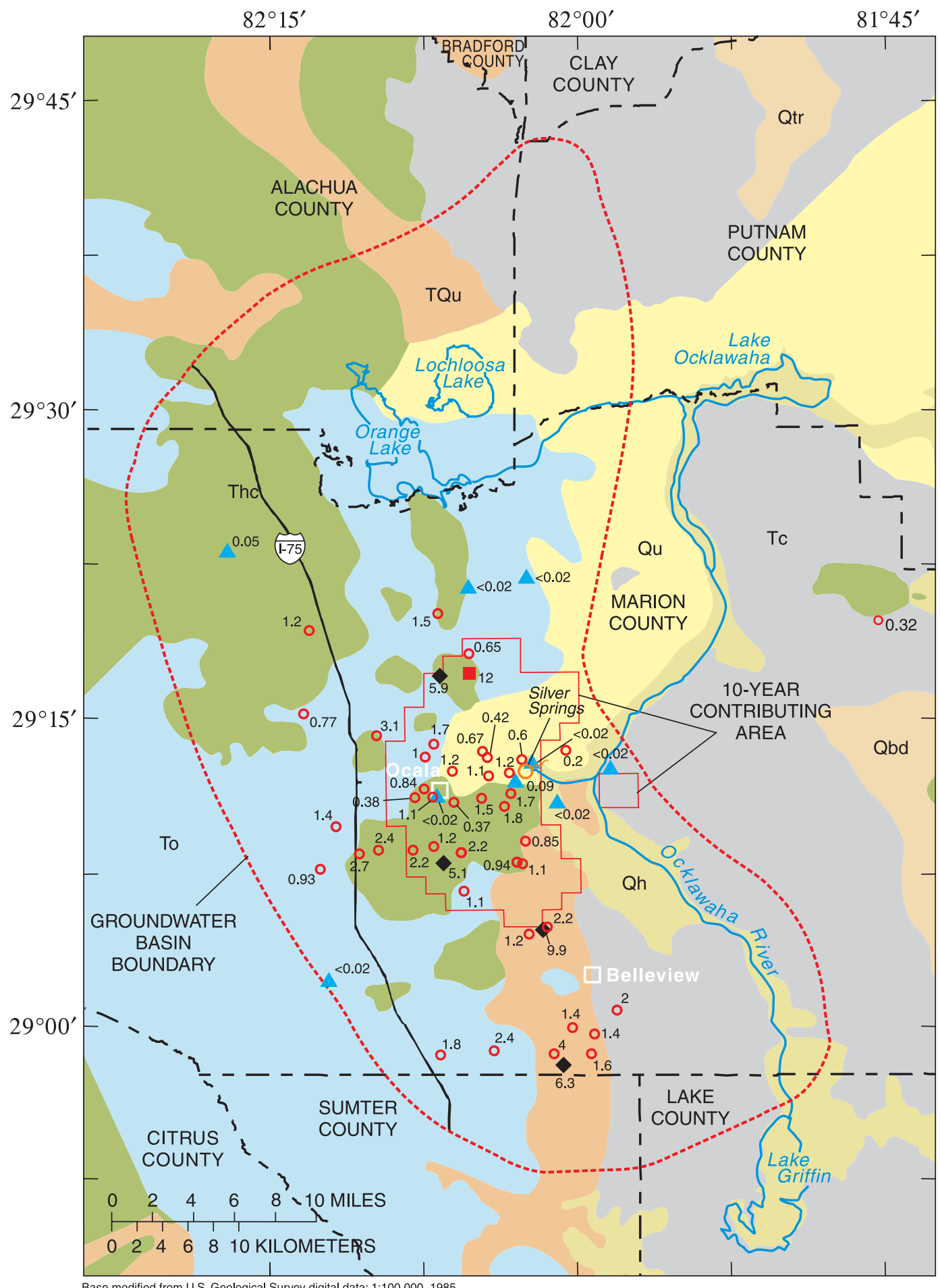

ase modified from U.S. Geological Survey digital data; 1:100,000, 1985

\section{EXPLANATION}

Holocene sediments

Qu Quaternary undifferentiated sediments

Pleistocene / Holocene beach abd Qtr ridge and Trail Ridge sediments
TQu Tertiary-Quaternary undifferentiated sediments Pliocene Cypresshead Formation

Miocene Hawthorn Group Eocene Ocala Limestone
WELL AND NITRATE CONCENTRATION IN MILLIGRAMS PER LITER:

$$
\begin{array}{rl}
<0.02 & <.2 \\
20 & .2 \text { to } 3 \\
6.3> & 3.01 \text { to } 10
\end{array}
$$$$
12 \square>10
$$

Figure 16. Nitrate-N concentrations in water from the Upper Floridan aquifer, Silver Springs basin. 

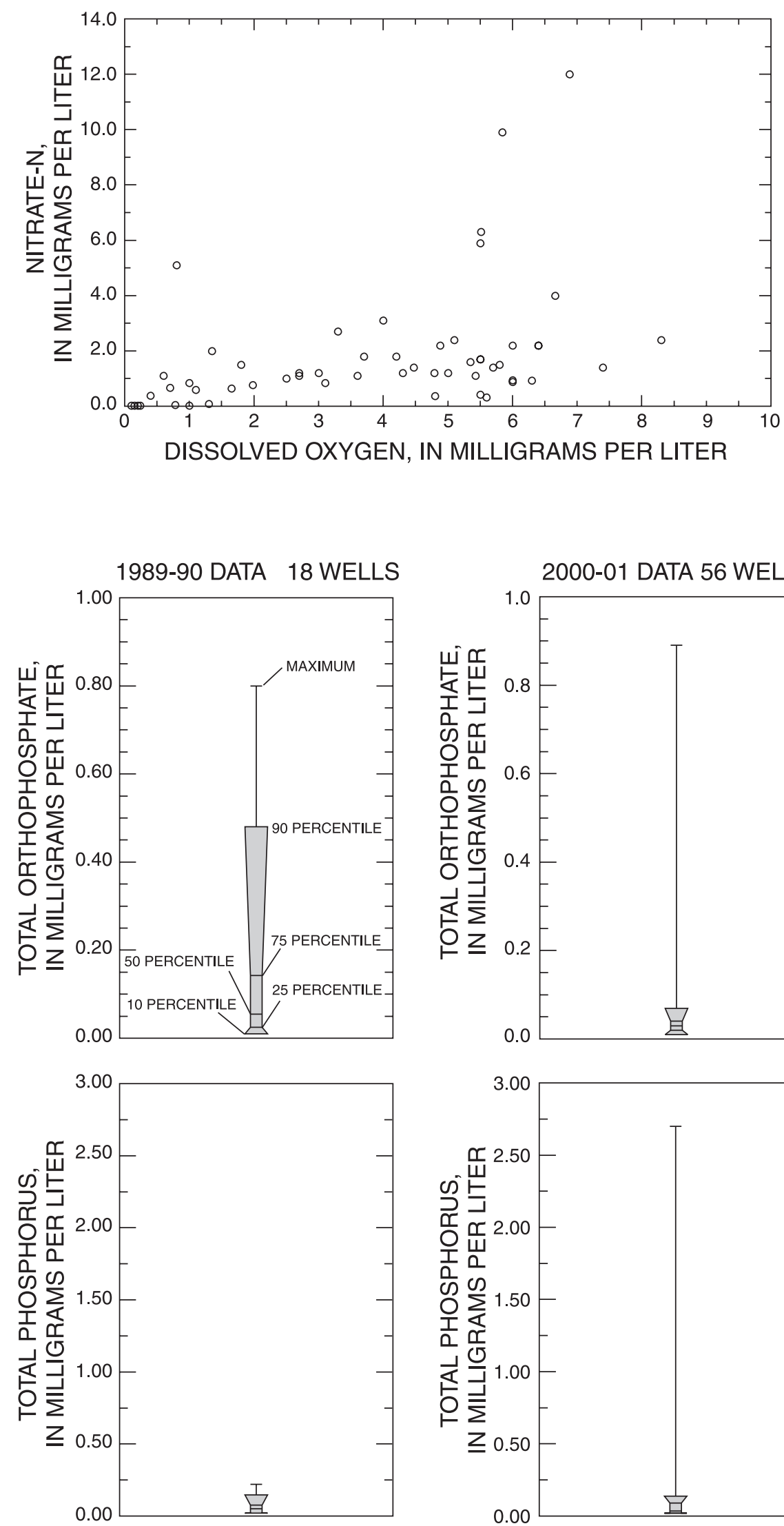
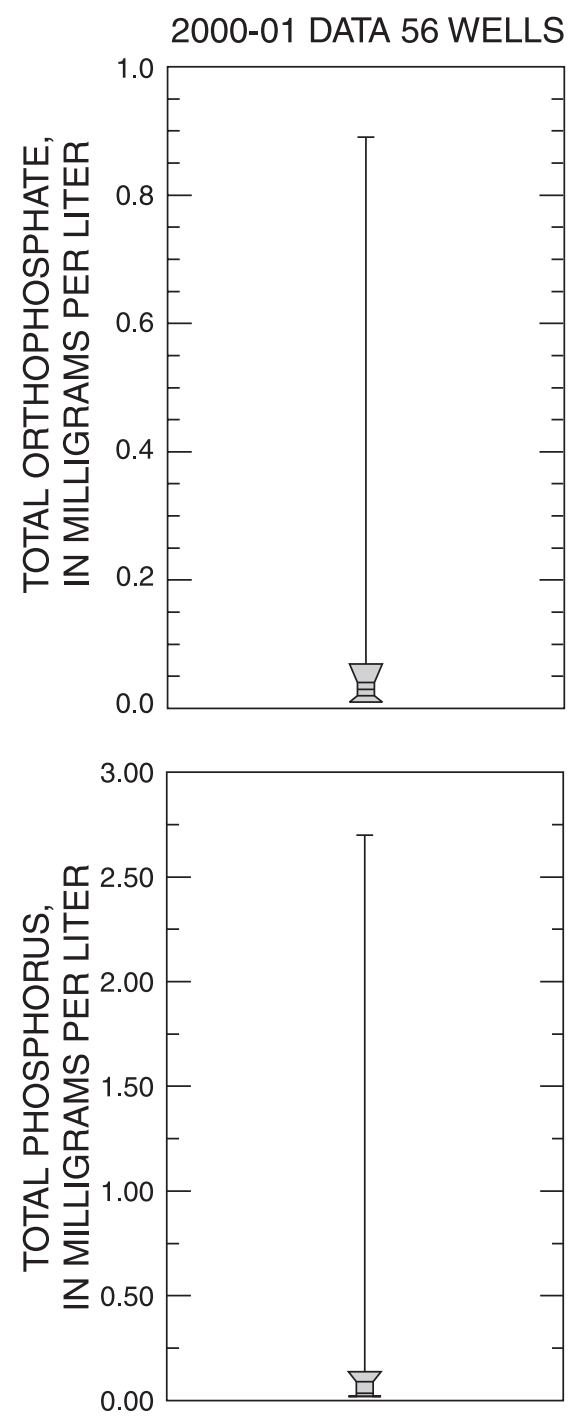

Figure 17. Nitrate- $\mathrm{N}$ as a function of dissolved oxygen in ground-water samples.
Figure 18. Total phosphorus and total orthophosphate in ground water, 1989-90 and 2000-01. 
Nutrient concentrations for water discharging from the Main Spring of Silver Springs for the period of record (1956-2004) also were compiled. The concentration of nitrate-N in water discharging from Silver Springs generally has increased over time (fig. 2). During the study period (1999-2002) nitrate-N concentrations in water from the Main Spring were approximately $0.9 \mathrm{mg} / \mathrm{L}$ (ranging from 0.8 to $1.1 \mathrm{mg} / \mathrm{L}$ ). Phosphorus data have been collected for water samples from the Main Spring since 1967. Total $P$ values ranged from less than the detection limit of 0.02 to $0.07 \mathrm{mg} / \mathrm{L}$; total ortho $P$ ranged from 0.02 to $0.07 \mathrm{mg} / \mathrm{L}$. Neither phosphorus constituent shows an increasing temporal trend.

\section{Comparison to Data from 1989-90}

Nutrient data from 56 wells sampled during this study also were compared to data from 25 wells sampled during 1989-90 (Phelps, 1994). The median nitrate-N concentration for water samples from the previous study was $1.04 \mathrm{mg} / \mathrm{L}$ compared to a median of $1.2 \mathrm{mg} / \mathrm{L}$ for the present study (fig. 13). The maximum value from the previous study was $3.6 \mathrm{mg} / \mathrm{L}$ whereas the maximum during this study was $12 \mathrm{mg} / \mathrm{L}$. Total orthophosphate had a similar range in both studies (fig. 18), although the median for the 1989-90 data was higher $(0.06 \mathrm{mg} / \mathrm{L})$ than for the data from the present study $(0.03 \mathrm{mg} / \mathrm{L})$. The maximum total $\mathrm{P}$ value for the 1989-90 data was 0.22 $\mathrm{mg} / \mathrm{L}$, compared to a maximum of $2.7 \mathrm{mg} / \mathrm{L}$ during the present study. Except for the maximum value, total $P$ values during the present study were in the same range as those from the previous study (1989-90). Median total P for $1989-90$ data was $0.05 \mathrm{mg} / \mathrm{L}$ compared to $0.04 \mathrm{mg} / \mathrm{L}$ for the present study.

Six wells were sampled during both studies; three of those wells are part of the Florida Department of Environmental Protection Very Intensely Studied Area network (2003). There are insufficient data to determine trends in nitrate-N concentrations (table 2). In water from one well (41), concentrations apparently increased; in another well (30), there was an apparent decrease. In the other wells, concentrations show little change.

\section{Relation of Nitrogen Concentrations to Land Use}

A question of interest to scientists and water managers is this: What are the effects of land use on groundwater chemistry, especially in a karst area such as the Silver Springs ground-water basin? To obtain a better understanding of the relation between land use and ground-water chemistry, wells were grouped according to reported 1995 land use at the site and concentrations of
nitrate-N in water samples were compared (table 3 ). Median concentrations were calculated for each group. The median was calculated for the 30 wells located in all types of urban areas; medians also were calculated for three urban subgroups of low-density residential, medium- and high-density residential, and for the group consisting of commercial, industrial, and recreation uses. The commercial-industrial-recreational group had the highest variability in concentration. The number of wells in some land-use type areas, such as transportation and utilities, is too small to provide a statistical characterization of that category. Also, 1995 land use may not accurately represent historic land use, which could have significantly affected ground-water chemistry.

The agricultural land-use areas had the highest median nitrate-N concentration $(1.70 \mathrm{mg} / \mathrm{L})$. The highest value of nitrate- $\mathrm{N}$ in the study $(12 \mathrm{mg} / \mathrm{L})$ also was in an area of agricultural land use, although it is uncertain whether the high concentration is related to land-use activities or to proximity of a septic tank on the property. For this reason, the statistics for agricultural land use also were calculated for all samples excluding the sample with the highest concentration. The median for that group of samples was 1.55 $\mathrm{mg} / \mathrm{L}$. The median nitrate-N for all urban areas was 1.15 $\mathrm{mg} / \mathrm{L}$. Low-density residential had the highest median of the urban subgroups, $1.40 \mathrm{mg} / \mathrm{L}$. Because fewer wells are located in rangeland and forests, those land-use areas were grouped together. That group had the lowest median concentration, $0.65 \mathrm{mg} / \mathrm{L}$. The relatively high value $(1.57$ $\mathrm{mg} / \mathrm{L}$ ) for the transportation/utilities land use could reflect the effects of stormwater runoff for road rights-of-way or could be affected by nearby land-use activities; for example, well 12 is a monitoring well downgradient from a wastewater land application site, but it is located in an electrical power transmission right-of-way.

The nonparametric Wilcoxon rank-sum test (Insightful Corporation, 2001) was used to test for differences in median nitrate concentrations in ground-water samples from agricultural, urban, and rangeland and forest (combined) land-use areas. Comparisons were made between each set of samples. At the 0.05 significance level, the differences between all data sets were significant.

Wells in the area contributing recharge to Silver Springs within an estimated 10-year travel time also were grouped by land-use type (table 3 ). The maximum nitrate$\mathrm{N}$ concentration for all urban land-use types occurred within the 10-year contributing area; the medians for all urban data and urban data within the 10-year contributing area were nearly the same. For agricultural land-use areas, the median values (both with and without the $12 \mathrm{mg} / \mathrm{L}$ value) were slightly lower in the 10 -year contributing area than in the entire study area. For rangeland and forest, the 
Table 2. Comparison of historic and current nitrate- $\mathrm{N}$ concentrations in filtered ground-water samples.

\begin{tabular}{ccccc}
\hline $\begin{array}{c}\text { Well } \\
\text { No. }\end{array}$ & Site & Date & $\begin{array}{c}\text { Nitrate-N } \\
\text { (milligrams } \\
\text { per liter) }\end{array}$ & 1995 land use \\
\hline 18 & 290838082103501 & $6 / 27 / 90$ & 2.5 & Specialty farms (horse farms) \\
& & $5 / 16 / 01$ & 2.7 & \\
\hline 29 & 291123082065001 & $5 / 23 / 90^{\mathrm{a}}$ & $.52^{\mathrm{b}}$ & Medium-high density residential \\
& & $1 / 26 / 95$ & .33 & \\
& & $8 / 14 / 01$ & .28 & \\
30 & 291123082075402 & $5 / 23 / 90^{\mathrm{a}}$ & $.84^{\mathrm{b}}$ & Commercial-parks or zoos \\
& & $1 / 18 / 95$ & .72 & \\
\hline 33 & 291148082072702 & $5 / 24 / 90^{\mathrm{a}}$ & $.60^{\mathrm{b}}$ & Medium-high density residential \\
& & $1 / 25 / 95$ & 1.2 & \\
& & $8 / 15 / 01$ & .84 & \\
\hline 35 & 291226082042001 & $6 / 21 / 89$ & $1.20^{\mathrm{b}}$ & Commercial-retail sales \\
& & $5 / 10 / 01$ & 1.10 & \\
\hline 41 & 291320082042301 & $6 / 28 / 90$ & .15 & Commercial-light industrial \\
& & $5 / 08 / 01$ & .42 & \\
\hline
\end{tabular}

${ }^{\mathrm{a}}$ Data from Florida Department of Environmental Protection Very Intensely Studied Area database. ${ }^{\mathrm{b}}$ Unfiltered sample.

Table 3. Concentrations nitrate- $\mathrm{N}$ in ground-water samples grouped by 1995 land use at well locations.

[LUCODE refers to appendix B; concentrations in milligrams per liter; <, less than; --, no data. Number of wells: All, all study wells; 10-year, subset of study wells sampled within 10-year contributing area]

\begin{tabular}{|c|c|c|c|c|c|c|c|c|c|}
\hline \multirow[t]{2}{*}{ LUCODE } & \multirow[t]{2}{*}{1995 land use } & \multicolumn{2}{|c|}{$\begin{array}{l}\text { No. } \\
\text { of wells }\end{array}$} & \multicolumn{2}{|c|}{ Minimum } & \multicolumn{2}{|c|}{ Maximum } & \multicolumn{2}{|c|}{ Median } \\
\hline & & All & 10-year & All & 10-year & All & 10-year & All & 10-year \\
\hline$<2000$ & All urban & 29 & 20 & $<0.02$ & $<0.02$ & 5.9 & 5.9 & 1.15 & 1.10 \\
\hline$<1200$ & Low-density residential & 10 & 4 & $<.02$ & .65 & 2.2 & 2.2 & 1.40 & 1.70 \\
\hline $1200-<1400$ & $\begin{array}{l}\text { Medium- and high- } \\
\text { density residential }\end{array}$ & 7 & 6 & $<.02$ & $<.02$ & 3.1 & 1.8 & 1.10 & 1.05 \\
\hline $1400-1999$ & $\begin{array}{l}\text { Commercial, industrial, } \\
\text { recreation }\end{array}$ & 12 & 10 & .37 & .37 & 5.9 & 5.9 & 1.15 & .88 \\
\hline 2000-2999 & Agricultural & 13 & 5 & .05 & .85 & 12 & 12.0 & 1.70 & 1.20 \\
\hline 2000-2999 & $\begin{array}{l}\text { Agricultural (without the } \\
\text { maximum value of } 12 \text { ) }\end{array}$ & 12 & 4 & .05 & .85 & 9.9 & 1.7 & 1.55 & 1.15 \\
\hline $3000-4999$ & Rangeland and forest & 11 & 4 & $<.02$ & $<.02$ & 2.2 & 2.2 & .09 & .65 \\
\hline $8000-9000$ & Transportation, utilities & 3 & 1 & .88 & -- & 4.0 & -- & 1.57 & .91 \\
\hline
\end{tabular}


median value in the 10-year contributing area is higher than the entire study area, perhaps because there are urbanized areas upgradient of some of the wells in rangeland and forest areas within the 10-year contributing area.

These results are somewhat different from those reported by the USGS National Water Quality Assessment (NAWQA) Program. In that study, water from wells in unconfined areas of the Upper Floridan aquifer in northeastern Florida and eastern Georgia had nitrate- $\mathrm{N}$ concentrations ranging from less than 0.02 to $10.00 \mathrm{mg} / \mathrm{L}$, with a median of $0.28 \mathrm{mg} / \mathrm{L}$, in urban areas. In agricultural areas (Berndt, 1996), the range was from less than 0.02 to $2.5 \mathrm{mg} / \mathrm{L}$, with a median of $0.40 \mathrm{mg} / \mathrm{L}$. These differences may be due in part to the greater number of wells sampled (42 in agricultural areas and 96 in urban areas), or because the range of geologic conditions varied more widely over the NAWQA study area. Also, the specific land-use practices (that is, type of crops raised) may have been different in the NAWQA area than in Marion County.

\section{Nitrogen Isotopes}

To provide insight about the sources of nitrogen in ground water in the study area, water samples were collected for analysis of the ratio of ${ }^{15} \mathrm{~N} /{ }^{14} \mathrm{~N}$ at 37 wells and three springs of the Silver Springs group. Wells were selected to be representative of the various land-use types in the study area. Values in ground-water samples ranged from -0.5 to 11.5 per mil (fig. 19). In general, values less than 6 per mil are indicative of the effects of artificial (inorganic) nitrogen (fertilizers). Values between 6 to 9 per mil are representative of mixed inorganic and organic sources or a soil organic source; values greater than 9 are indicative of organic nitrogen (from human or animal wastes) (Coplen, 1993; Katz and others, 1999). The median value for all ground-water samples, 4.9 per mil, is within (but near the top of) the range for inorganic sources.
The areal distribution of ${ }^{15} \mathrm{~N} /{ }^{14} \mathrm{~N}$ is shown in figure 20 . The values of ${ }^{15} \mathrm{~N} /{ }^{14} \mathrm{~N}$, along with the land use and geologic formation at each well, are shown in appendix A. Well sites were grouped by 1995 land-use type so statistics for ${ }^{15} \mathrm{~N} /{ }^{14} \mathrm{~N}$ values could be computed for each group (fig. 19). For 17 wells in urban land-use areas, the ratio ranged from -0.5 to 10.8 per mil, with a median of 5.4 per mil. Values for agricultural land-use areas (11 wells) ranged from 1.9 to 8.9 per mil, with a median of 4.8 per mil. For rangeland and forested land areas, the range was 2.2 to 11.5 per mil, with a median of 4.1 per mil. The three sites in transportation, communication, or utilities land-use areas had values of $-0.2,2.7$, and 5.2 per mil, respectively. The median for urban land uses (5.4 per mil) is slightly higher (indicating more organic nitrogen) but the medians for all groups were within the range of generally inorganic sources. Land-use designations should be used with caution, however. For example, land use at well 11 is designated as agricultural although it is located within a spray field for wastewater land application. The ${ }^{15} \mathrm{~N} /{ }^{14} \mathrm{~N}$ ratio for that sample was 8.9 per mil, which is close to the range indicating mostly organic N. A nearby monitoring well (well 12) is in the right-of-way for an electrical power transmission line and land use for that site is indicated as such. The ${ }^{15} \mathrm{~N} /{ }^{14} \mathrm{~N}$ ratio for that sample was 5.2 per mil, which is in the mixed sources range. The ${ }^{15} \mathrm{~N} /{ }^{14} \mathrm{~N}$ ratio for the sample with the highest nitrate-N concentration (12 mg/L, well 49) was 7.1 per mil. The two wells with very low ratios (well 17, nitrate- $\mathrm{N}=0.94 \mathrm{mg} / \mathrm{L}$, and well 27 , nitrate- $\mathrm{N}=0.37 \mathrm{mg} / \mathrm{L}$ ) are not known to be near sources of fertilizer or wastewater N. Although the Upper Floridan aquifer is semiconfined at these well locations, the ${ }^{15} \mathrm{~N} /{ }^{14} \mathrm{~N}$ ratios of the water could be representative of nitrate- $\mathrm{N}$ from atmospheric deposition or could represent effects of upgradient fertilizer use.

The Main Spring of Silver Springs was sampled four times during the study for ${ }^{15} \mathrm{~N} /{ }^{14} \mathrm{~N}$ ratios (table 4). Two distinct nitrogen isotope ratios were observed: two values indicating inorganic nitrogen sources (3.7 and 3.8 per mil) and two values indicating mixed sources with a strong

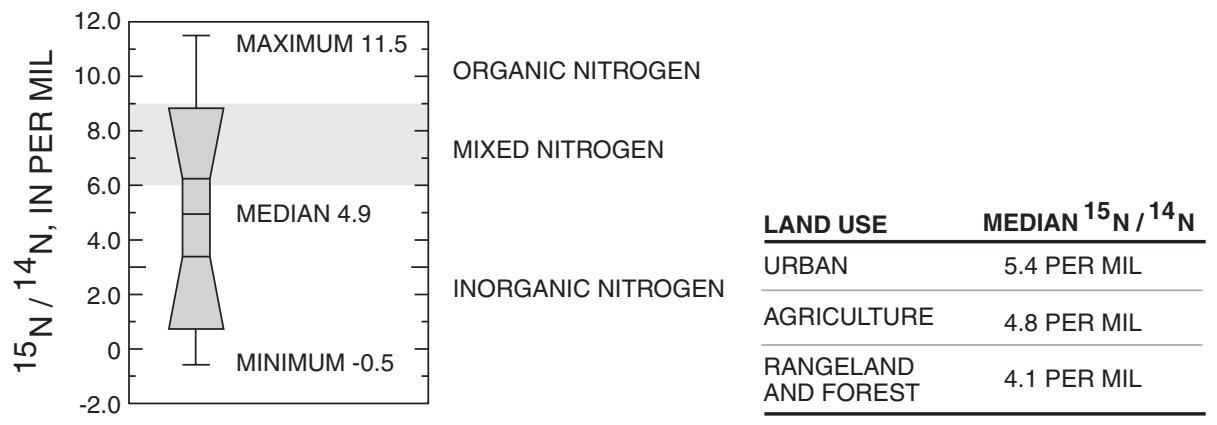

Figure 19. Range of ${ }^{15} \mathrm{~N} /{ }^{14} \mathrm{~N}$ for ground-water samples. 


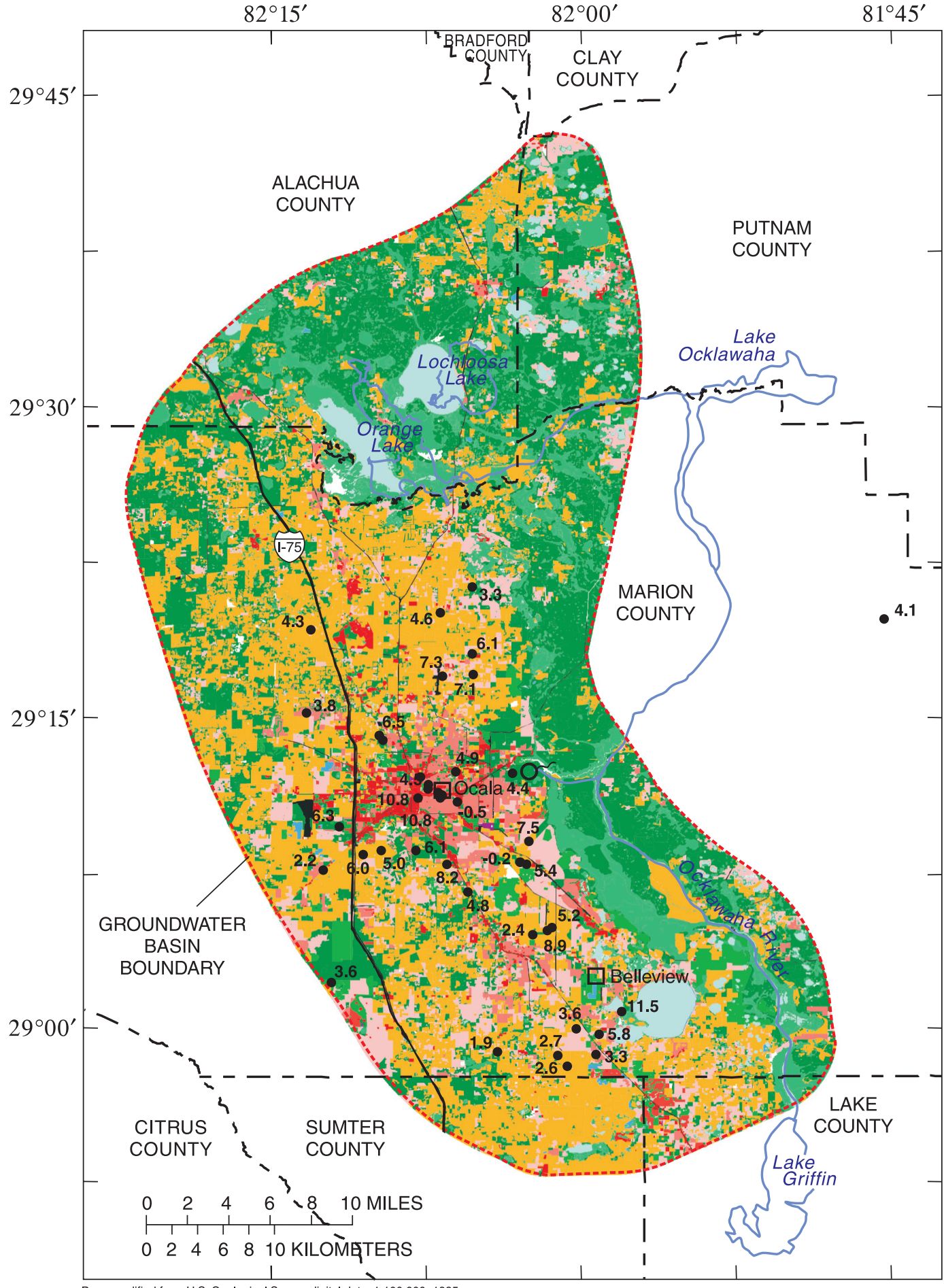

Base modified from U.S. Geological Survey digital data; 1:100,000, 1985
Universal Transverse Mercator projection, zone 17

EXPLANATION

Land-use data from St. Johns River Water Management District (1999)

Low Density Residential

Medium and High Density Residential

Commercial / Industrial

Recreation / Open Land
Rangeland

Pasture

Livestock Operations

Horse Farms
Horticultural Operations

Silvicultural Operations

Upland Forests

Water
Wetlands

Barren Land

Transp., Comm., Util.

Sewage Treatment

$$
\bullet^{3.6} \text { WELL AND RATIO OF }{ }^{15} \mathrm{~N} /{ }^{14} \mathrm{~N} \text { IN PER MIL O } \text { O }^{-} \text {SILVER SPRINGS }
$$

Figure 20. Areal distribution of ${ }^{15} \mathrm{~N} /{ }^{14} \mathrm{~N}$ for ground-water samples. 
Table 4. Isotopic data for water samples from Silver Springs, 2001-2002.

[Isotopic ratios are in per mil. ${ }^{2} \mathrm{H} /{ }^{1} \mathrm{H}$, deuterium, hydrogen; ${ }^{15} \mathrm{~N} /{ }^{14} \mathrm{~N}$, nitrogen-15, nitrogen- $14 ;{ }^{18} \mathrm{O} /{ }^{16} \mathrm{O}$, oxygen-18, oxygen-16; mg/L, milligrams per liter; $\mu \mathrm{S} / \mathrm{cm}$, microseimens per centimeter; ${ }^{\circ} \mathrm{C}$, degrees Celsius; $\mathrm{ft}^{3} / \mathrm{s}$, cubic foot per second; dup., duplicate; --, not analyzed]

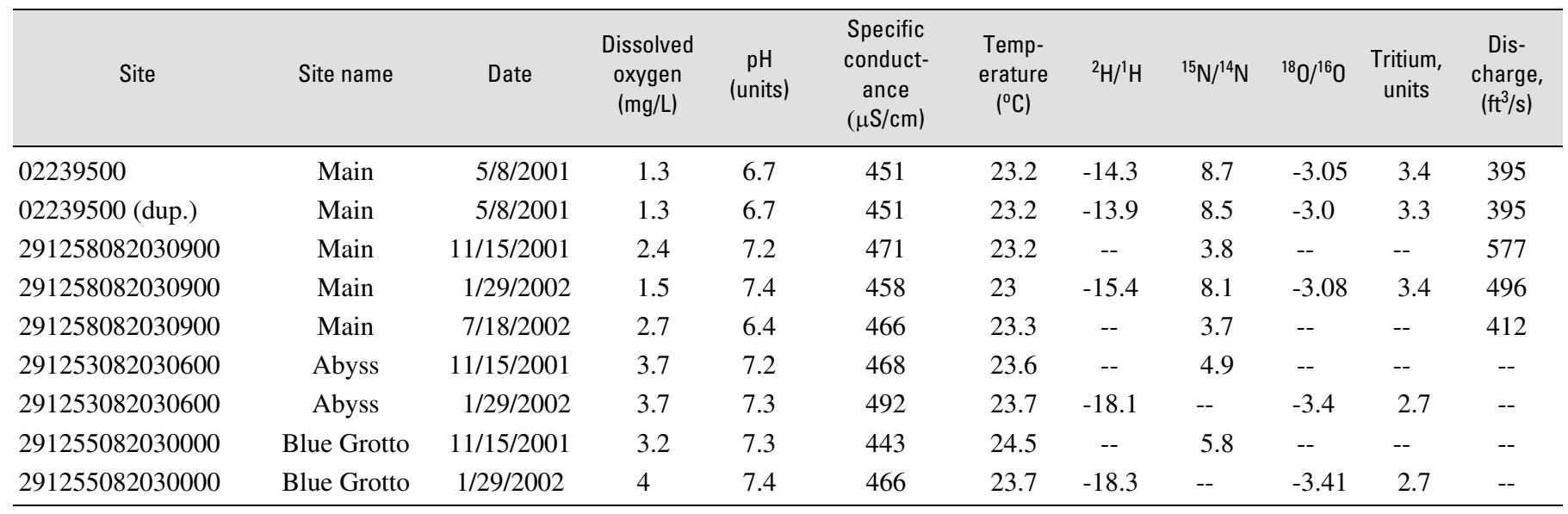

influence of organic sources ( 8.1 and 8.7 per mil). It has been hypothesized that during low flows, the discharge of Silver Springs is derived mainly from flow through the porous aquifer matrix and, therefore, might be more influenced by the load of inorganic nitrogen that was added continuously to the basin over time by fertilizer applications. All of the nitrogen isotope determinations were made at spring discharge values less than the long-term average flow; for this range of flow there was no apparent relation between ${ }^{15} \mathrm{~N} /{ }^{14} \mathrm{~N}$ ratio and spring discharge.

Divers reported at least two conduits discharging water of different temperatures in the cavern beneath the Main Spring (R. Spechler, U.S. Geological Survey, Orlando, Fla., oral commun., 2003). Thus, it seems possible that the ${ }^{15} \mathrm{~N} /{ }^{14} \mathrm{~N}$ ratios measured during this study may reflect differences in the placement of the sampling pump during the various sampling events, rather than an actual variation of the ratio. Another possible explanation is that the distribution of antecedent rainfall in the recharge areas could cause one or the other conduit system to be contributing more flow during different sampling events. Variations in tritium concentrations in water from the Main Spring (Faulkner, 1973), discussed in a later section of this report, also point to a rather rapidly changing distribution of source waters to the Main Spring.

To summarize nitrate- $\mathrm{N}$ and nitrogen isotope results, nitrate- $\mathrm{N}$ concentrations in agricultural areas were higher (median value $1.7 \mathrm{mg} / \mathrm{L}$ ) than in urban (median 1.15 $\mathrm{mg} / \mathrm{L}$ ) or rangeland and forest areas (median $0.09 \mathrm{mg} / \mathrm{L}$ ). In agricultural areas, the median ${ }^{15} \mathrm{~N} /{ }^{14} \mathrm{~N}$ was 4.8 per mil, indicating mostly inorganic (fertilizer) sources. In urban areas, the median ${ }^{15} \mathrm{~N} /{ }^{14} \mathrm{~N}$ was 5.4 per mil, indicating more influence of organic $\mathrm{N}$ sources. Thus, in both agricultural and urban areas, fertilizer is an important inorganic source of $\mathrm{N}$ in ground water, and therefore, in spring water as well. The influence of organic $\mathrm{N}$ is more apparent in urban areas than in agricultural areas.

\section{Wastewater Indicators}

Because nitrogen isotope data indicated mixed organic and inorganic nitrogen sources for many water samples, water samples also were analyzed for organic constituents commonly found in domestic and industrial wastewater to gain additional insight into the sources of nitrogen in ground water and in Silver Springs. Thirty-five wells and three springs of the Silver Springs group were sampled for a suite of 63 compounds (table 5). Compounds found in detergents and personal care products, pesticides, and compounds that result from industrial processes were included. Some of the compounds are known or suspected endocrine disrupters. A total of 38 compounds was detected, nearly all in very low concentrations.

The most frequently detected compound was the insecticide N,N-diethyl-meta-toluamide (DEET), which was detected in water from 27 of the 35 wells sampled (fig. 21). DEET is an insecticide designed for application to the skin to repel, rather than kill, mosquitoes. The U.S. Environmental Protection Agency (1998) determined that DEET is in Toxicity Category III (slightly toxic, the second lowest of four categories). The chemical is of low solubility and does not break down easily. DEET is not 
Table 5. Summary of compounds commonly detected in wastewater and detections in water samples.

[Endocrine Disrupting Potential: K, known, S, suspected. F, fungicide; H, herbicide; I, insecticide; GUP, general use pesticide; FR, flame retardant; Manuf, manufacturing; --, not detected]

\begin{tabular}{|c|c|c|c|c|}
\hline Compound names & $\begin{array}{l}\text { Endocrine } \\
\text { distrupting } \\
\text { potential }\end{array}$ & $\begin{array}{l}\text { Chemical } \\
\text { Abstract Service } \\
\text { registry Nos. }\end{array}$ & $\begin{array}{l}\text { Common use, application, } \\
\text { or occurrence }\end{array}$ & $\begin{array}{c}\text { No. } \\
\text { of } \\
\text { detec- } \\
\text { tions }\end{array}$ \\
\hline 1,4-Dichlorobenzene & $\mathrm{S}$ & $106-46-7$ & moth repellent, fumigant, deodorant & -- \\
\hline 1-Methylnaphthalene & & $90-12-0$ & nearly equal concentrations (2-5\%) in gasoline/diesel/crude & 1 \\
\hline 2,6-Dimethylnaphthalene & & $58-14-2$ & indicator of diesel, kerosene (not much in gasoline) & 1 \\
\hline 3-beta-Coprostanol & & $360-68-9$ & usually a carnivore fecal indicator & 1 \\
\hline 3-Methyl-1(H)-indole (skatol) & & $83-34-1$ & fragrance: odor in feces and coal tar & 1 \\
\hline 3-tert-Butyl-4-hydroxy anisole (BHA) & $\mathrm{K}$ & $25013-16-5$ & antioxidant, preservative & -- \\
\hline 4-Cumylphenol & $\mathrm{K}$ & $599-64-4$ & nonionic detergent metabolite & -- \\
\hline 4-n-Octylphenol & $\mathrm{K}$ & $1806-26-4$ & nonionic detergent metabolite & -- \\
\hline $\begin{array}{l}\text { Acetyl hexamethyl tetrahydronaphthalene } \\
\text { (AHTN) }\end{array}$ & & $21145-77-7$ & $\begin{array}{l}\text { fragrance: musk, widespread usage, persistent in } \\
\text { ground water }\end{array}$ & 1 \\
\hline Anthracene & & $120-12-7$ & wood preservative, in tar/diesel/crude (not gasoline) & -- \\
\hline Anthraquinone & & $84-65-1$ & Manuf dye/textiles; seed treatment, bird repellent & -- \\
\hline Benzo(a)pyrene & $\mathrm{K}$ & $50-32-8$ & $\begin{array}{l}\text { regulated polychlorinated aromatic hydrocarbon, used in } \\
\text { cancer research }\end{array}$ & -- \\
\hline Benzophenone & $\mathrm{S}$ & $119-61-9$ & fixative for perfumes and soaps & 2 \\
\hline beta-Sitosterol & & $83-46-5$ & generally a plant sterol & 1 \\
\hline beta-Stigmastanol & & $19466-47-8$ & generally a plant sterol & -- \\
\hline Bisphenol A & $\mathrm{K}$ & $80-05-7$ & Manuf polycarbonate resins; antioxidant, FR & 11 \\
\hline Carbazole & & $86-74-8$ & Manuf dyes, explosives, and lubricants, I & -- \\
\hline Chlorpyrifos & $\mathrm{K}$ & 2921-88-2 & domestic pest/termite control; highly restricted (2000) & -- \\
\hline Cholesterol & & $57-88-5$ & often a fecal indicator, also a plant sterol & 4 \\
\hline Cotinine & & $486-56-6$ & primary nicotine metabolite & -- \\
\hline Diazinon & $\mathrm{K}$ & $333-41-5$ & $\mathrm{I},>40 \%$ nonagricultural uses, ants, flies, etc. & -- \\
\hline Dichlorvos & $\mathrm{S}$ & $62-73-7$ & I, pet collars, fly spray; breakdown of naled \& trichlofon & -- \\
\hline d-Limonene & & $5989-27-5$ & $\mathrm{~F}$, antimicrobial, antiviral; fragrance in aerosols & 1 \\
\hline Fluoranthene & & $206-44-0$ & common in coal tar/asphalt (not gasoline/diesel) & -- \\
\hline $\begin{array}{l}\text { Hexahydrohexamethyl } \\
\text { Cyclopentabenzopyran (HHCB) }\end{array}$ & & $1222-05-5$ & $\begin{array}{l}\text { fragrance: musk; widespread usage, persistent in } \\
\text { ground-water }\end{array}$ & -- \\
\hline Indole & & $120-72-9$ & pesticide inert, fragrance: coffee & 1 \\
\hline Isoborneol & & $124-76-5$ & fragrance: perfumery, disinfectants & -- \\
\hline Isophorone & & $78-59-1$ & solvent for lacquers, plastics, oils, silicon, resins & 4 \\
\hline Isopropylbenzene (cumene) & & $98-82-8$ & Manuf phenol/acetone; component of fuels/paint thinner & -- \\
\hline Isoquinoline & & $119-65-3$ & flavors and fragrances & -- \\
\hline Menthol & & $89-78-1$ & cigarettes, cough drops, liniment, mouthwash & -- \\
\hline
\end{tabular}


Table 5. Summary of compounds commonly detected in wastewater and detections in water samples. (Continued)

[Endocrine Disrupting Potential: K, known, S, suspected. F, fungicide; H, herbicide; I, insecticide; GUP, general use pesticide; FR, flame retardant; Manuf, manufacturing; --, not detected]

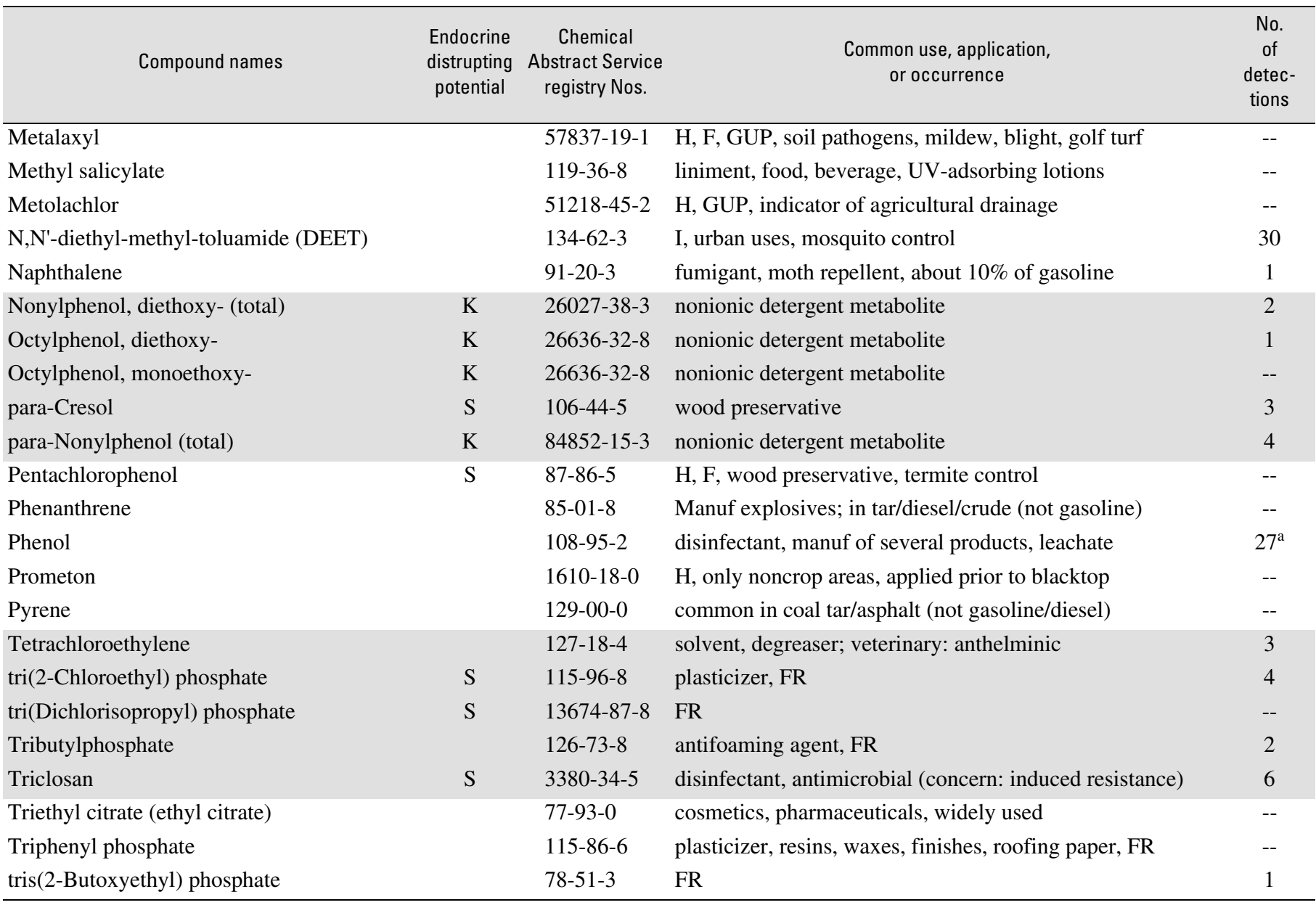

${ }^{\text {a}}$ Phenol detections are observed in laboratory blanks, so no interpretation of phenol data is made.

sprayed over large areas for insect control. The primary use is as a personal insect repellent for humans, but DEET also has been used on some insect repellent collars for pets and as a spray to repel flies from horses. DEET enters the wastewater when the user bathes or launders clothing. It was beyond the scope of this study to estimate the relative importance of use on animals as a source of DEET (as compared to human use) in the Silver Springs basin; however, based on widespread detections in all land-use areas, wastewater is likely the major source of DEET in the study area. DEET appears to be a useful tracer for the presence of wastewater. In a nation-wide sampling of surface water (139 streams), Buxton and Kolpin (2002) detected DEET in 74 percent of the samples.

The presence or absence of DEET in ground-water samples was not related to land use. The compound was detected in water from 11 of 15 wells located in all urban land use areas ( 8 of 10 residential areas and 3 of 5 commercial, industrial or recreational areas). DEET was detected in water from 8 of 9 wells in agricultural areas, 5 of 8 wells in rangeland or forested areas, and all 3 wells in transportation or power transmission areas.

The presence or absence of DEET in ground water was related to geologic conditions at well sites, however. Of the 35 wells sampled, nine were in the outcrop area of the Ocala Limestone, the principal water-bearing unit of the Upper Floridan aquifer, and DEET was detected in all nine samples. In contrast, all of the water samples in which DEET was not detected were collected from wells in areas where the Ocala Limestone is covered by younger sediments (fig. 21). The presence of DEET in some of the water samples from areas where the Upper Floridan aquifer is covered by younger sediments can be explained by recharge water containing DEET that enters the Upper Floridan aquifer in unconfined areas and moves downgradient to confined areas. 


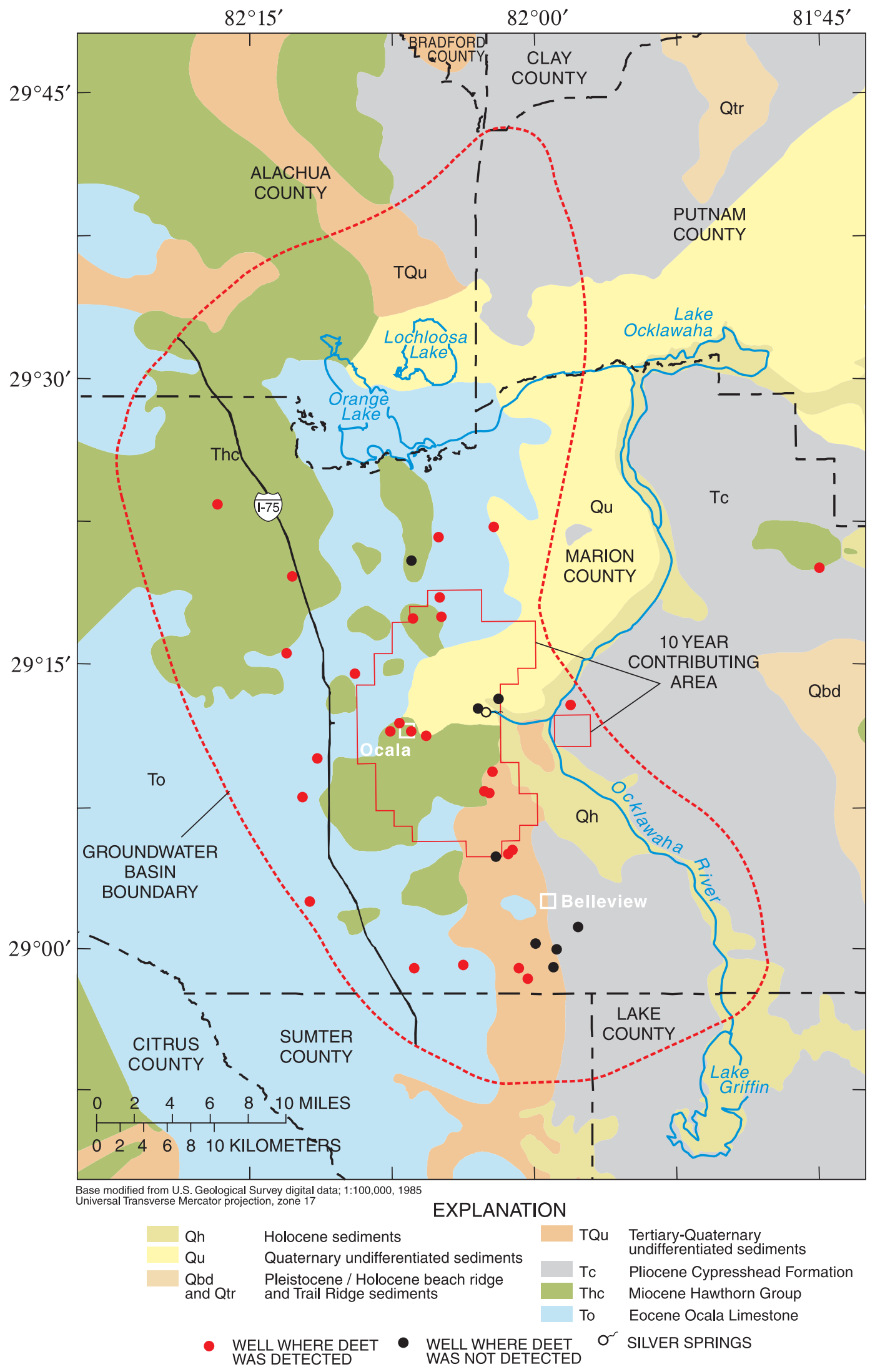

Figure 21. Wells where the insecticide DEET was detected in ground-water samples. 
Other compounds detected in ground-water samples included phenol (24 wells), bisphenol-A (10 wells), and triclosan (6 wells) (table 5). Some of the lower phenol occurrences may be erroneous because problems with phenol detections in laboratory blanks (S. Zaugg, USGS National Water Quality Laboratory, Denver, Colo., oral commun., 2002) make interpretation of low-level phenol data difficult. However, levels of the compound higher than $0.5 \mu \mathrm{g} / \mathrm{L}$ were quantified in samples from 16 of the 24 wells.

In most samples, only one or two compounds were detected; however, samples from two wells (23 and 30) contained more compounds and in higher levels than other ground-water samples. Water from well 30, located in a park in downtown Ocala, contained DEET $(5.8 \mu \mathrm{g} / \mathrm{L})$ and 19 other compounds including caffeine $(0.14 \mu \mathrm{g} / \mathrm{L})$. Caffeine breaks down quickly (Heberer, 2002) and is considered an indicator of relatively recent recharge by wastewater. The concentration of cholesterol, a fecal indicator, was $5.2 \mu \mathrm{g} / \mathrm{L}$. Phenol was detected at a concentration of $6.3 \mu \mathrm{g} / \mathrm{L}$ and the concentration of bisphenol-A was $4.4 \mu \mathrm{g} / \mathrm{L}$. The sample from well 23 , in a recreation area that formerly was used as a pasture and is surrounded by residential areas using OSDS, contained three fecal indicators: 3-beta-coprostanol ( $2.4 \mu \mathrm{g} / \mathrm{L})$; cholesterol (7.2 $\mu \mathrm{g} / \mathrm{L})$; and 3-methyl-1(H)-indole $(0.23 \mu \mathrm{g} / \mathrm{L})$. Nonylphenol, diethoxy- (total) (NPEO2), a nonionic detergent metabolite and a known endocrine disrupter, and DEET also were detected in this sample.

Water samples from the Main Spring and two other springs of the Silver Springs group were analyzed for wastewater constituents in January 2002. To confirm results, the Main Spring was resampled in duplicate in July 2002. DEET was detected in all three spring samples from January and confirmed in the Main Spring in July. Levels ranged from the detection limit of approximately 0.03 to $1.2 \mu \mathrm{g} / \mathrm{L}$ (app. A). Phenol was detected in two of the January samples and isophorone in one sample.

Phenol also was detected in the July samples ( 0.34 and $0.88 \mu \mathrm{g} / \mathrm{L}$ levels); caffeine was detected in one sample but not in the duplicate.

\section{Dating Spring Water using Anthropogenic Tracers}

In January 2002, water samples were collected from the Main Spring, the Abyss, and the Blue Grotto of the Silver Springs group and analyzed for concentrations of dissolved gases, $\mathrm{CFCs}, \mathrm{SF}_{6}$, and ${ }^{3} \mathrm{H} /{ }^{3} \mathrm{He}_{\text {trit }}$ for the purpose of dating the young fraction of ground water discharging from the springs.
Spring-water samples were analyzed for dissolved gases (table 6) to determine if excess $\mathrm{N}_{2}$ (above equilibrium concentrations) or excess air were present. Excess air is trapped in pores of the unsaturated zone and dissolved under hydrostatic pressure. The amount of excess air present can be determined by comparing the ratio of $\mathrm{N}_{2}$ to argon (Ar) in air to the equilibrium solubility ratio of $\mathrm{N}_{2}$ to $\mathrm{Ar}$ in water (Busenberg and others, 1993). The presence of excess $\mathrm{N}_{2}$ in water samples may indicate that denitrification is occurring or has occurred sometime in the past. Denitrification can reduce nitrate concentration and increase the ${ }^{15} \mathrm{~N} /{ }^{14} \mathrm{~N}$ values in an aquifer because the lighter isotope is used preferentially (Hubner, 1986; Mariotti and others, 1988). Concentrations of $\mathrm{N}_{2}$ in spring-water samples were consistent with atmospheric equilibrium during ground-water recharge (table 6; fig. 22), excess air values were low, and estimated recharge temperatures (about $23^{\circ} \mathrm{C}$ ) were reasonable for Florida spring-water samples. These data (table 6; fig. 22), coupled with the fact that DO concentrations of the spring-water samples ranged from about 1.3 to $3.7 \mathrm{mg} / \mathrm{L}$ (app. A) (and denitrification is an anaerobic process), indicate that little, if any, denitrification is occurring in the immediate vicinity of the springs.

Anthropogenic activities released low but measurable quantities of ${ }^{3} \mathrm{H}, \mathrm{CFCs}$, and $\mathrm{SF}_{6}$ into the atmosphere during the later half of the twentieth century (Cook and Böhlke, 2000; Plummer and others, 1993). Rainfall incorporates the concentrations of the chemicals at the time it infiltrates into the ground. The ratio ${ }^{3} \mathrm{H} /{ }^{3} \mathrm{He}_{\text {trit }}$ and concentrations of $\mathrm{SF}_{6}$ and $\mathrm{CFC}$ can be used to date relatively young (less than about 50 years) ground water. Gas exchange between air and the unsaturated zone is assumed to be rapid, but also that shallow ground water remains closed to gas exchange after recharge (Schlosser and others, 1989; Plummer and Busenberg, 2000; Busenberg and Plummer, 2000). The ratio ${ }^{3} \mathrm{H} /{ }^{3} \mathrm{He}_{\text {trit }}$ generally is not affected by contamination, sorption, or microbial degradation processes that can change the concentrations of $\mathrm{SF}_{6}$ or CFCs in various ways (Plummer and others, 1998; Busenberg and Plummer, 2000). The concentrations of ${ }^{3} \mathrm{H},{ }^{3} \mathrm{He}_{\text {trit }}$, CFCs, and $\mathrm{SF}_{6}$ can be affected by hydrodynamic dispersion and mixing of different age waters to varying extents (Solomon and Sudicky, 1991; Reilly and others, 1994). Also, some rocks are terrigenic sources of ${ }^{4} \mathrm{He}$ and $\mathrm{SF}_{6}$, which can complicate the interpretation. For these reasons, several methods usually are used to date ground water; concordant ages from all methods indicate that the water was not affected by mixing of water from various sources or by dispersion. 
Table 6. Dissolved gas data and summary of sulfur hexafluoride data for water samples collected at Silver Springs, January 29, 2002

$\left[\mathrm{N}_{2}\right.$, elemental nitrogen; $\mathrm{Ar}$, argon; $\mathrm{O}_{2}$, oxygen; $\mathrm{CO}_{2}$, carbon dioxide; $\mathrm{CH}_{4}$, methane; $\mathrm{SF}_{6}$, sulfur hexafluoride. ${ }^{\circ} \mathrm{C}$, degrees Celcius; mg/L, milligrams per liter; cc STP/L, cubic centimeters at standard temperature and pressure, per liter; $\left.\mathrm{P}_{\left(\mathrm{SF}_{6}\right.}\right)$, partial pressure of $\mathrm{SF}_{6}$; pptv, parts per trillion by volume; sl, sample lost]

\begin{tabular}{lcccccccccccc}
\hline \multicolumn{1}{c}{ Site } & $\begin{array}{c}\text { Site } \\
\text { name }\end{array}$ & $\begin{array}{c}\text { Field } \\
\text { temperature } \\
\left({ }^{\circ} \mathrm{C}\right)\end{array}$ & $\begin{array}{c}\mathrm{N}_{2} \\
(\mathrm{mg} / \mathrm{L})\end{array}$ & $\begin{array}{c}\mathrm{Ar} \\
(\mathrm{mg} / \mathrm{L})\end{array}$ & $\begin{array}{c}\mathrm{O}_{2} \\
(\mathrm{mg} / \mathrm{L})\end{array}$ & $\begin{array}{c}\mathrm{CO}_{2} \\
(\mathrm{mg} / \mathrm{L})\end{array}$ & $\begin{array}{c}\mathrm{CH}_{4} \\
(\mathrm{mg} / \mathrm{L})\end{array}$ & $\begin{array}{c}\text { Excess } \\
\text { air } \\
(\mathrm{cc} S \mathrm{ST} / \mathrm{L})\end{array}$ & $\begin{array}{c}\mathrm{P}\left(\mathrm{SF}_{6}\right) \\
(\mathrm{pptv})\end{array}$ & $\begin{array}{c}\mathrm{Model} \mathrm{SF}_{6} \\
\text { recharge } \\
\text { year }\end{array}$ & $\begin{array}{c}\text { Model } \mathrm{SF}_{6} \\
\text { age } \\
\text { (years) }\end{array}$ \\
\hline 02239500 & Main & 23.0 & 16.851 & 0.5639 & 1.49 & 14.57 & 0.0000 & 2.9 & 1.755 & 1986.5 & 15.5 \\
02239500 & Main & 23.0 & $\mathrm{sl}$ & $\mathrm{sl}$ & $\mathrm{sl}$ & $\mathrm{sl}$ & $\mathrm{sl}$ & $\mathrm{sl}$ & 1.790 & 1987.0 & 15 \\
291253082030600 & Abyss & 23.7 & 15.959 & .5545 & 1.30 & 12.23 & .0000 & 1.7 & 3.203 & 1993.5 & 8.5 \\
291253082030600 & Abyss & 23.7 & 15.939 & .5531 & 1.49 & 11.91 & .0000 & 1.7 & 3.045 & 1993.0 & 9 \\
291255082030000 & Blue Grotto & 23.7 & 16.161 & .5558 & 1.63 & 10.85 & .0000 & 2.0 & 3.794 & 1996.0 & 6 \\
291255082030000 & Blue Grotto & 23.7 & 16.079 & .5565 & 1.62 & 10.88 & .0000 & 1.8 & 3.717 & 1996.0 & 6 \\
\hline
\end{tabular}

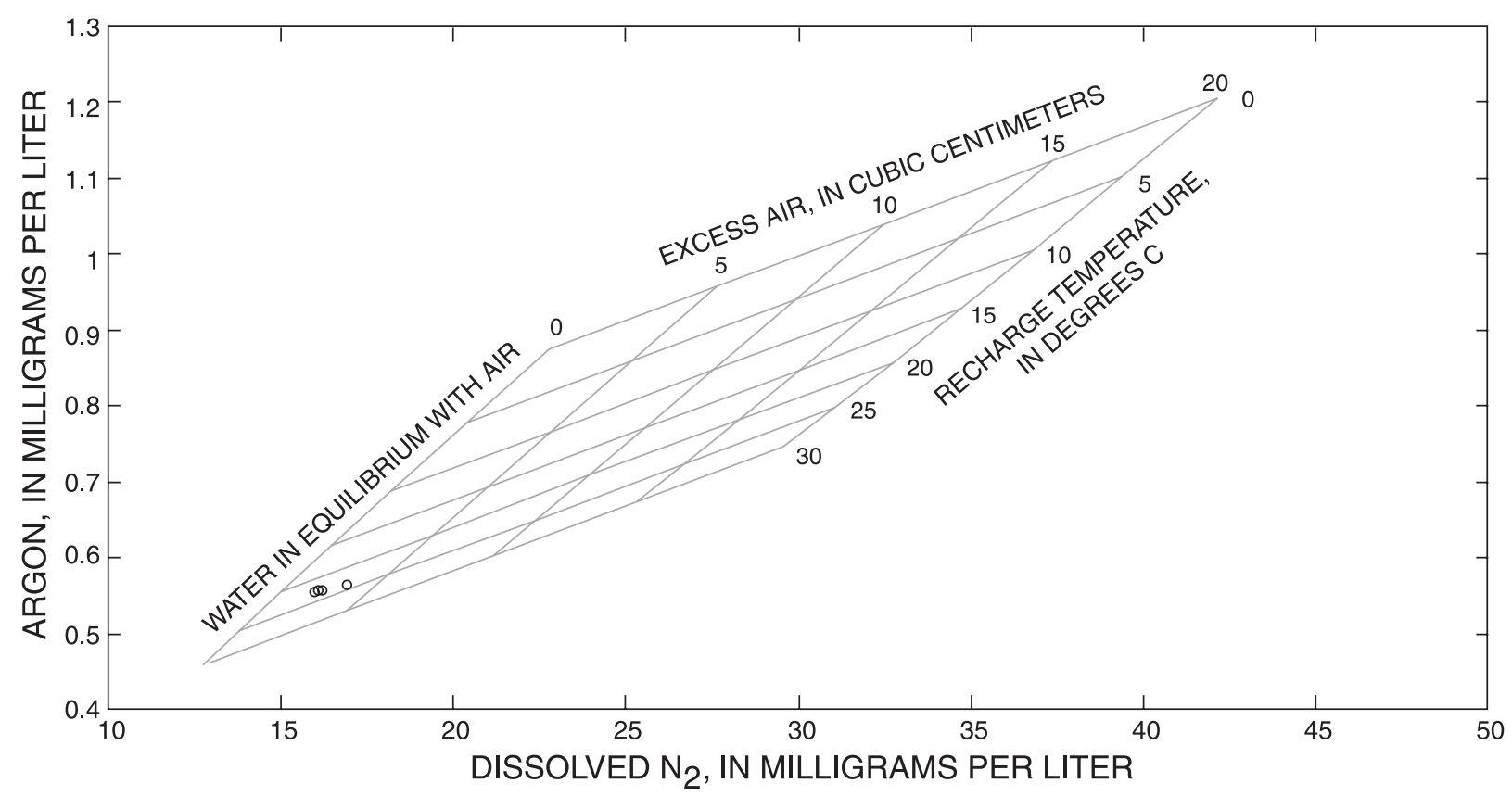

Figure 22. Concentrations of dissolved argon and $\mathrm{N}_{2}$ in water samples from Silver Springs compared to equilibrium concentrations of air in water.

Apparent ages of ground water are based on the piston-flow model assumption that after a tracer is isolated from the atmosphere at the time of recharge, it is incorporated into a parcel of ground water that moves from the recharge area with the mean velocity of ground water (Zuber, 1986). All flow lines are assumed to have similar velocities (which is not the case in an aquifer with dual porosity, such as the Floridan aquifer system). It is furthermore assumed that dispersion, diffusion, or advec- tion of the tracer are negligible. The tracer concentration (or ratio, as is the case for ${ }^{3} \mathrm{H} /{ }^{3} \mathrm{He}$ trit ) is assumed to depend solely on a time-dependent decay function. The application of more complex models, such as an exponential model (Zuber, 1986) or a binary mixing model (Plummer and Busenberg, 2000), which were applied to springs discharging from the Floridan aquifer system in the Suwannee River basin (Katz and others, 1999), could give a better understanding of the flow system. 
Table 7. Summary of tritium-helium age data using piston-flow model for water samples collected at Silver Springs, January $29,2002$.

[TU, tritium units; TU $=1{ }^{3} \mathrm{H}$ atom per $10{ }^{18}$ hydrogen atoms; $1 \sigma$, sigma; ${ }^{3} \mathrm{He}_{\text {trit }}$, helium derived from tritium; $\delta \mathrm{He}$, delta helium; ${ }^{4} \mathrm{He}$, helium; Ne, neon; ${ }^{3} \mathrm{H} /{ }^{3} \mathrm{He}$, tritium-helium; cc STP/g, cubic centimeters at standard temperature and pressure, per gram]

\begin{tabular}{lccccccccccc}
\hline \multicolumn{1}{c}{ Site } & $\begin{array}{c}\text { Site } \\
\text { name }\end{array}$ & $\begin{array}{c}\text { Tritium } \\
\text { (TU) }\end{array}$ & $\begin{array}{c}\text { Tritium } \\
\text { error, } 1 \sigma \\
\text { (TU) }\end{array}$ & $\begin{array}{c}{ }^{3} \mathrm{He}_{\text {trit }} \text { (TU) } \\
\text { (percent) }\end{array}$ & $\begin{array}{c}\delta^{3} \mathrm{He} \\
\text { (cc STP/g) }\end{array}$ & $\begin{array}{c}{ }^{4} \mathrm{He} \\
\text { (cc STP/g) }\end{array}$ & $\begin{array}{c}\text { Percent } \\
\begin{array}{c}{ }^{4} \mathrm{He} \\
\text { terrigenic }\end{array}\end{array}$ & $\begin{array}{c}{ }^{3} \mathrm{H} /{ }^{3} \mathrm{He} \\
\text { age } \\
\text { (years) }\end{array}$ & $\begin{array}{c}{ }^{3} \mathrm{H} /{ }^{3} \mathrm{He} \text { age } \\
\text { error } \\
\text { (years) }\end{array}$ & $\begin{array}{c}\mathrm{Apparent} \\
\text { recharge } \\
\text { year }\end{array}$ \\
\hline 02239500 & Main & 3.4 & 0.09 & 12.19 & -31.93 & $1.1067 \times 10^{-7}$ & $2.1205 \times 10^{-7}$ & 51.8 & 27.4 & 1.3 & $1974.6 \pm 1.3$ \\
291253082030600 & Abyss & 2.7 & .08 & 1.89 & 4.27 & $6.127 \times 10^{-8}$ & $2.3892 \times 10^{-7}$ & .3 & 9.9 & .6 & $1992 \pm 0.6$ \\
291255082030000 & Blue Grotto & 2.7 & .09 & 7.72 & 4.27 & $5.574 \times 10^{-8}$ & $1.9959 \times 10^{-7}$ & 10.7 & 18.9 & .5 & $1983 \pm 0.5$
\end{tabular}

Dating with $\mathrm{SF}_{6}$ can in some instances be complicated by the presence of natural background sources of $\mathrm{SF}_{6}$ from rocks or by addition of excess air during recharge. Excess air values for the samples were low (table 7). Rock sources include fluorite and dolomite (Busenberg and Plummer, 2000). Phosphate deposits in the Hawthorn Group might be a potential source of fluorite; however, $\mathrm{SF}_{6}$ contamination related to mineralogic conditions in north-central Florida has not been documented. Dolomites are present in deeper zones of the Floridan aquifer system; the $\mathrm{SF}_{6}$ content of those dolomites is unknown. If the dolomites contain excess $\mathrm{SF}_{6}$, mixing with even a small fraction of water from a deeper zone could account for $\mathrm{SF}_{6}$ concentrations that result in anomalously younger ages.

Dating of water with ${ }^{3} \mathrm{H} /{ }^{3} \mathrm{He}$ is possible because ${ }^{3} \mathrm{H}$ that was released into the atmosphere by nuclear weapons testing during the 1950 s and 1960 s decays to ${ }^{3} \mathrm{He}$ with a half-life of 12.43 years (Schlosser, 1992). For the purposes of dating ground water, tritiogenic helium $\left({ }^{3} \mathrm{He}_{\text {trit }}\right)$ is estimated from the total ${ }^{3} \mathrm{He}$ by taking into account terrigenic (earth-derived) ${ }^{3} \mathrm{He}$ from minerals in the earth's crust or mantle and ${ }^{3} \mathrm{He}$ in equilibrium with present-day atmospheric conditions. Neon $(\mathrm{Ne})$ is used as an indicator of atmospheric helium to separate ${ }^{3} \mathrm{He}_{\text {trit }}$ from the total ${ }^{3} \mathrm{He}$ of the water sample (Schlosser, 1992). The sample from the Main Spring contained relatively high (about 52 percent) terrigenic helium — perhaps from uranium in sediments of the Hawthorn Group (Cathcart, 1992).

Tritium-helium-3 data for the spring-water samples (table 7) indicated generally older ages than $\mathrm{SF}_{6}$ data (about 27 years for the Main Spring and about 18 years for the Blue Grotto); however, the ${ }^{3} \mathrm{H} /{ }^{3} \mathrm{He}_{\text {trit }}$ age for the Abyss (about 10 years) agreed with the $\mathrm{SF}_{6}$ age. The greater ${ }^{3} \mathrm{H} /{ }^{3} \mathrm{He}_{\text {trit }}$ ages for the samples from the Main Spring and the Blue Grotto could result from the fact that ground water discharging from those springs is a mixture of water from both shallow flow paths and deeper flow paths containing older water with terrigenic $\mathrm{SF}_{6}$ but no bomb tritium. On the other hand, the flow system of the Abyss is relatively shallow and rapid and includes no mixing with older water. One way to assess if ${ }^{3} \mathrm{H} /{ }^{3} \mathrm{He}_{\text {trit }}$ results were affected by mixing of waters from different flow paths is to compare the reconstructed original ${ }^{3} \mathrm{H}$ content $\left({ }^{3} \mathrm{H}\right.$ at time of recharge) of the spring-water samples (which equals the recently measured ${ }^{3} \mathrm{H}$ content plus ${ }^{3} \mathrm{He}_{\text {trit }}$ ) with the historical records of ${ }^{3} \mathrm{H}$ in rainfall (Katz, 2004). Data for rainfall measured at the International Atomic Energy Agency monitoring station at Ocala, Fla., were reported by Michel (1989). Values that do not plot near the rainfall input curve for the estimated year of recharge may indicate the effects of mixing. All of the reconstructed points plot near the rainfall curve, consistent with the apparent recharge years as estimated from the ${ }^{3} \mathrm{H} /{ }^{3} \mathrm{He}_{\text {trit }}$ data (fig 23).

Even though the initial ${ }^{3} \mathrm{H}$ value for the samples plot close to the rainfall curve, mixing cannot be completely ruled out, as demonstrated by Aeschbach-Hertig and others (1998). Multiple mixing scenarios could serendipitously result in reconstructed ${ }^{3} \mathrm{H} /{ }^{3} \mathrm{He}$ trit values that plot near the rainfall input curve. The conduit system that provides flow to the springs is complex and poorly understood. This is apparent from an examination of tritium data for the Main Spring in May and July 1967 reported by Faulkner (1973). The values were 150 tritium units (TU) in May 1967 (when average discharge was about $850 \mathrm{ft}^{3} / \mathrm{s}$ ) and $25 \mathrm{TU}$ in July 1967 (average discharge about $800 \mathrm{ft}^{3} / \mathrm{s}$, which is approximately the long-term average flow). Calculations assuming exponential mixing suggest that the observed tritium in the spring water could represent a mean age of about 1 to 5 years for the May samples but about 50 years for the July sample (L. Niel Plummer, USGS, Reston, Va., written commun., 2004). 


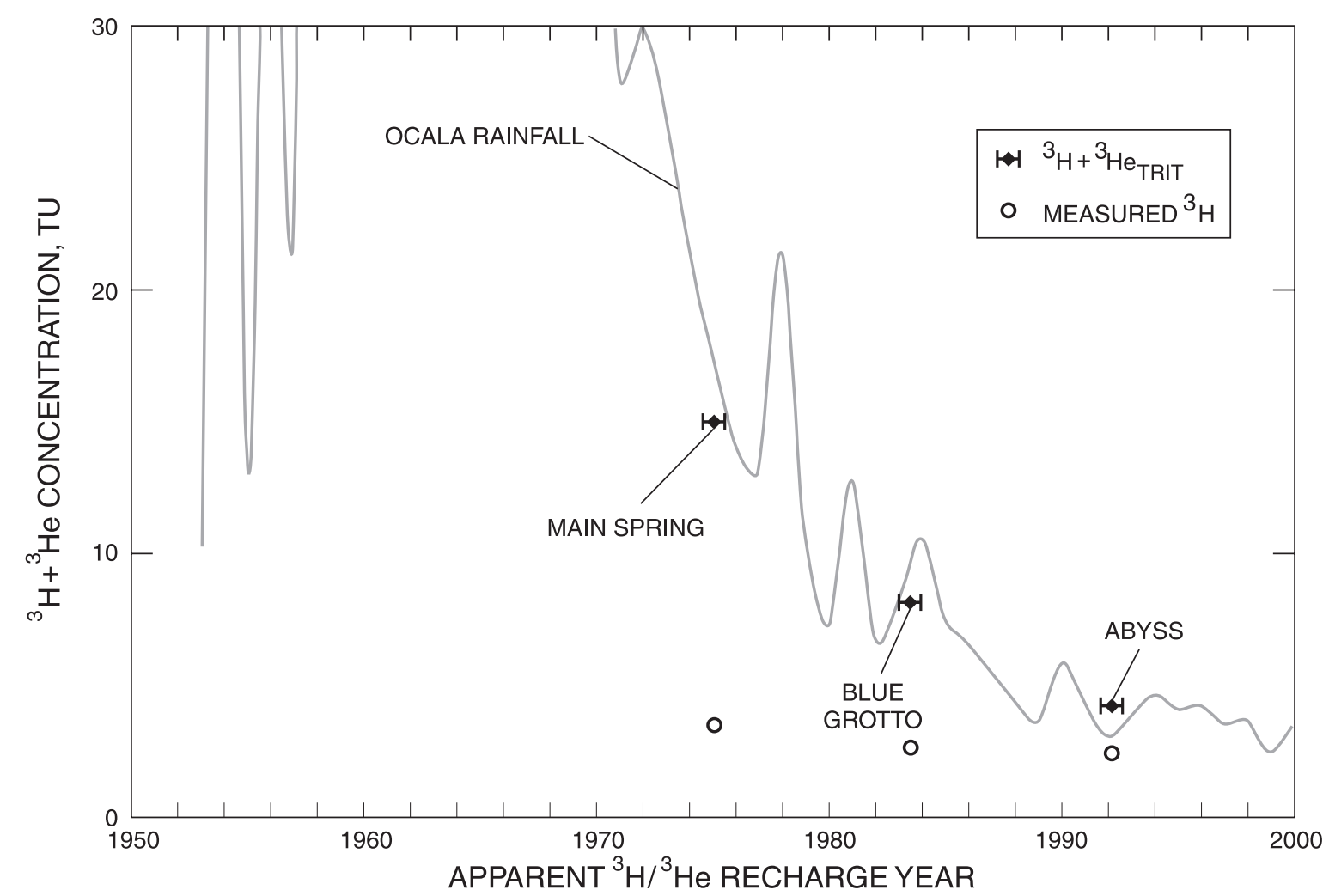

Figure 23. Comparison of measured tritium and tritiogenic helium concentrations of water samples from Silver Springs and the tritium concentration of rainfall at Ocala, Florida (from Michael, 1989, and Michael, unpublished data).

Such large variations in ${ }^{3} \mathrm{H}$ concentrations in spring water over a narrow discharge range are unusual. If the ${ }^{3} \mathrm{H}$ values reported by Faulkner (1973) are correct, this indicates that the age distribution of spring water can shift rapidly from mostly young to mostly older water with only small fluctuations in total spring discharge.

CFC data could not be used for dating the spring water because all samples had CFC concentrations that were higher than atmospheric concentrations of CFCs (table 8). Excessive CFC concentrations generally are caused by the influence of wastewater from treatment plants or OSDS (Busenberg and Plummer, 1992) or from industrial waste sources. The spring water samples also contained detectable concentrations of halon and methyl chloroform, the sources of which could be industrial (G. Casile, USGS, CFC Laboratory, Reston, Va., oral commun., 2002). The presence of these chemicals in addition to the detections of DEET in spring waters confirm that at least some water discharging from Silver Springs is affected by anthropogenic activities.
To summarize the results of dating, both $\mathrm{SF}_{6}$ and ${ }^{3} \mathrm{H} /{ }^{3} \mathrm{He}_{\text {trit }}$ data indicate that recharge occurred in the early 1990s for water from the Abyss. Apparently, water from that spring follows a relatively simple, shallow flow path and is not affected by mixing or dispersion. On the other hand, the water discharging from the Blue Grotto and the Main Spring may be affected by mixing of waters from different flow paths. Additional sampling from the Main Spring under differing flow conditions could add to the understanding of the flow system, as could collection of samples from discrete points in various flow paths within the spring cavern. All three springs are affected by the presence of wastewater in the contributing area, as evidenced by the presence of DEET and high CFC concentrations in all the samples. The complex conduit flow system contributing water to Silver Springs makes it difficult to draw conclusions about the time lag between introduction of $\mathrm{N}$ loads in the basin and nitrate-N concentrations in the spring water. However, the fact that water from the spring is relatively young (less than 30 years) indicates it likely is important to minimize $\mathrm{N}$ loading within the contributing area of 30-year travel times or less. 
Table 8. Concentrations of chlorofluorocarbons (CFC) in water samples collected at Silver Springs, January 29, 2002.

$\left[{ }^{\circ} \mathrm{C}\right.$, degrees Celcius; $\mathrm{pg} / \mathrm{kg}$, picogram per kilogram. Note: $\mathrm{CFC}$ concentrations in all water samples are higher than values in equilibrium with 2002 atmospheric conditions; therefore, age calculation not possible]

\begin{tabular}{lcccccc}
\hline \multicolumn{1}{c}{ Site } & Site & $\begin{array}{c}\text { Recharge } \\
\text { temperature } \\
\left({ }^{\circ} \mathrm{C}\right)\end{array}$ & $\begin{array}{c}\text { Ampule } \\
\text { number }\end{array}$ & & \multicolumn{3}{c}{$\begin{array}{c}\text { Concentration } \\
\text { in solution, pg/kg }\end{array}$} \\
\cline { 6 - 8 } & Main & 23.5 & 3 & 1,629 & 898 & 166 \\
02239500 & Main & 23.5 & 4 & 1,670 & 872 & 159 \\
02239500 & Main & 23.5 & 5 & 1,541 & 849 & 166 \\
291253082030600 & Abyss & 22.6 & 2 & 1,541 & 1,191 & 1,209 \\
291253082030600 & Abyss & 22.6 & 4 & 1,523 & 1,158 & 1,192 \\
291253082030600 & Abyss & 22.6 & 5 & 1,607 & 1,255 & 1,257 \\
291255082030000 & Blue Grotto & 22.8 & 2 & 1,445 & 1,009 & 1,376 \\
291255082030000 & Blue Grotto & 22.8 & 4 & 1,418 & 977 & 1,458 \\
291255082030000 & Blue Grotto & 22.8 & 5 & 1,528 & 1,075 & 1,359 \\
\hline
\end{tabular}

\section{Summary and Conclusions}

Silver Springs, in central Marion County, Florida, is the largest nontidal spring group in Florida, with an average discharge of 796 cubic feet per second for 1932-2002. The spring group (three main springs and numerous smaller springs) is an important natural feature, forming the headwaters of the Silver River, and supporting a diverse ecosystem. It is also a significant recreational, cultural, and economic asset for north-central Florida. Nitrate concentration in the water from the Main Spring has increased with time. Nitrate enrichment of surface waters results in the growth of nuisance vegetation and in oxygen depletion in the water.

In much of the basin supplying ground water that supports the spring discharge, the limestone of the Floridan aquifer system is at or near land surface, so recharge occurs rapidly. Where the Upper Floridan aquifer is unconfined-as is the case in most of the basin-nutrients leached at land surface can easily percolate vertically into the aquifer. Land-use activities within the Silver Springs ground-water basin in Marion County historically have been predominantly agricultural. However, rapid population growth in the City of Ocala and surrounding rural areas has resulted in major land-use changes. A basin-wide evaluation of the occurrence and distribution of nitrate in the Silver Springs basin was undertaken to enhance understanding of the processes by which nutrients enter and move through the ground-water flow system. This included the possible effects of past and present land-use activities on water chemistry. Chemical constituent concentrations in ground water were documented and the possible effects of localized hydrogeologic conditions (that is, unconfined or confined aquifer) on nitrate concentrations were assessed.

Water that discharges from Silver Springs originates from the Floridan aquifer system in north-central Florida. Delineation of the ground-water basin (the area contributing flow to the spring) historically was based on the potentiometric surface of the Upper Floridan aquifer by connecting points perpendicular to the potentiometric contours. The delineation of the basin can change over time as the potentiometric surface fluctuates. Seasonal fluctuations of water levels in wells in the area generally are about 3 to 5 feet. Computer models provide another approach to delineate a ground-water basin. By adding particle tracking to a ground-water flow model, the area contributing recharge to a spring for a particular range of travel times can be delineated. The contributing area for Silver Springs based on travel times up to 500 years is smaller than the area delineated on the basis of the potentiometric surface, extending farther south but not as far west or north. 
Sources of nitrogen in ground water in the Silver Springs basin include atmospheric deposition, fertilizers used in agricultural and urban areas, and human and animal wastes. The total rate of atmospheric deposition averaged about 2,000,000 kilograms per year (kg/yr) total nitrogen from 1979-2000. Nitrogen production by livestock was about 3,500,000 kg/yr in the mid-1970s and by the late $1990 \mathrm{~s}$ averaged about $2,500,00 \mathrm{~kg} / \mathrm{yr}$. Total nitrogen load from agricultural fertilizer use (based on recommended application rates for various crops) averaged about $1,000,000 \mathrm{~kg} / \mathrm{yr}$. The actual loads of nitrogen reaching the ground water from atmospheric deposition, livestock, and agricultural fertilization are difficult to quantify. As little as 10 percent of atmospheric and animal nitrogen may reach the ground water. Nitrogen reaching the ground water from residential turf fertilization was estimated to have increased from $114,000 \mathrm{~kg}$ in 1977 to $727,000 \mathrm{~kg}$ in 1995 . The nitrogen load reaching the ground water from golf course fertilization in 2000 was estimated to be $500,000 \mathrm{~kg}$. Nitrogen load to the ground water from municipal wastewater and septic tanks totaled about $1,000,000 \mathrm{~kg}$ in 2000 .

During 2000-01, 56 wells in the Silver Springs ground-water basin were sampled for major ions, nutrients, and some trace constituents. Selected wells also were sampled for a suite of constituents commonly found in wastewater and for nitrogen isotopes. Wells were selected to represent both confined and unconfined conditions for the Upper Floridan aquifer, as well as a variety of land-use types. Data from the present study were compared to data collected from 25 wells sampled in 1989-90. For the 2000-01 data, calcium concentrations ranged from 24 to 176 milligrams per liter $(\mathrm{mg} / \mathrm{L})$, with a median of $72 \mathrm{mg} / \mathrm{L}$; sulfate values ranged from 0.6 to $400 \mathrm{mg} / \mathrm{L}$, with a median of $20 \mathrm{mg} / \mathrm{L}$. For the 1989-90 data, the median calcium concentration was $82 \mathrm{mg} / \mathrm{L}$, and the median sulfate concentration was $45 \mathrm{mg} / \mathrm{L}$. These differences probably resulted because this study included more deep wells than the previous study.

Concentrations of dissolved oxygen, nitrite-plusnitrate (nitrate-N), and phosphorus varied widely among the ground-water samples collected during this study. Dissolved oxygen concentrations ranged from 0.1 to $8.3 \mathrm{mg} / \mathrm{L}$. Dissolved oxygen generally is high in unconfined areas of the Upper Floridan aquifer but high values also occur in confined areas, such as in the southern part of the basin. This could be due to local variations in aquifer confinement that are not apparent on a regionallymapped scale. Concentrations of nitrate- $\mathrm{N}$ ranged from less than the detection limit of 0.02 to $12 \mathrm{mg} / \mathrm{L}$ with a median of $1.2 \mathrm{mg} / \mathrm{L}$. Concentrations of total orthophos- phate ranged from 0.01 to $0.89 \mathrm{mg} / \mathrm{L}$, with a median of $0.03 \mathrm{mg} / \mathrm{L}$; total phosphorus ranged from 0.02 to $2.7 \mathrm{mg} / \mathrm{L}$ with a median of $0.04 \mathrm{mg} / \mathrm{L}$. For data from 1989-90, the median nitrate-N was $1.04 \mathrm{mg} / \mathrm{L}$, and the maximum was $3.6 \mathrm{mg} / \mathrm{L}$. Total orthophosphate had a similar range in both studies (fig. 18), although the median for the 1989-90 data was higher $(0.06 \mathrm{mg} / \mathrm{L})$ than for the data from the present study $(0.03 \mathrm{mg} / \mathrm{L})$. The maximum total $\mathrm{P}$ value for the 1989-90 data was $0.22 \mathrm{mg} / \mathrm{L}$, compared to a maximum of $2.7 \mathrm{mg} / \mathrm{L}$ during the present study. Except for the maximum value, total $P$ values during the present study were in the same range as those from the previous study (1989-90). Median total $P$ for $1989-90$ data was $0.05 \mathrm{mg} / \mathrm{L}$ compared to $0.04 \mathrm{mg} / \mathrm{L}$ for the present study.

To obtain a better understanding of the relation between land use and ground-water chemistry, wells were grouped according to reported 1995 land use at the site and concentrations of nitrate- $\mathrm{N}$ were compared. The agricultural land-use areas had the highest median concentration $(1.7 \mathrm{mg} / \mathrm{L})$. The highest value of nitrate-N $(12 \mathrm{mg} / \mathrm{L})$ was found in an area of agricultural land use, although it is uncertain whether the high concentration is related to land-use activities or to proximity of the septic tank on the property. Because fewer wells were located in rangeland and forests, those land-use areas were grouped together. This group had the lowest median nitrate- $\mathrm{N}$ concentration, $0.09 \mathrm{mg} / \mathrm{L}$. The commercial-industrial-recreational group had the highest variability in concentration.

Wells in the area contributing recharge to Silver Springs within a 10-year travel time also were grouped by land-use type. The maximum nitrate- $\mathrm{N}$ concentration measured in all urban land-use areas occurred within the 10 -year contributing area; the medians for all urban data and urban data within the 10-year contributing area were nearly the same. For agricultural land-use areas, the median values (both with and without the $12 \mathrm{mg} / \mathrm{L}$ value) were slightly lower in the 10-year contributing area than in the entire study area. For rangeland and forest, the median value in the 10-year contributing area is higher than the entire study area perhaps because there are urbanized areas upgradient of some of the wells in rangeland and forest areas within the 10-year contributing area.

To give insight into the sources of nitrogen in ground water in the study area, water samples were collected for analysis of the ratio of nitrogen isotopes at 37 wells and three springs of the Silver Springs group. Values in ground-water samples ranged from -0.5 to 11.5 per mil. Values less than 6 per mil generally are indicative of the effects of artificial (inorganic) nitrogen (fertilizers). Values between 6 to 9 per mil represent mixed inorganic and organic sources; values greater than 9 per mil are 
indicative of organic nitrogen (from human or animal wastes). The median value for all ground-water samples was 4.9 per mil. For wells in urban land use areas, the ratio ranged from -0.5 to 10.8 per mil, with a median of 5.4 per mil. Values for agricultural land use areas ranged from 1.9 to 8.9 per mil, with a median of 4.8 per mil. For values in rangeland and forested land areas, the range was 2.2 to 11.5 per mil, with a median of 4.1 per mil. The three sites in transportation, communication or utilities land use areas had values of $-0.2,2.7$, and 5.2, per mil, respectively. The median for urban land uses (5.4 per mil) is slightly higher (indicating more organic nitrogen); the medians for all groups were within the range of generally inorganic sources.

The Main Spring of Silver Springs was sampled four times during the study for the nitrogen isotope ratio. Two distinct nitrogen isotope ratios were observed: two values indicating inorganic nitrogen sources and two values indicating mixed sources with a strong influence of organic sources. The different ${ }^{15} \mathrm{~N} /{ }^{14} \mathrm{~N}$ ratios measured may be because different conduits were sampled as a result of unintended differences in placement of the sampling pump during the various sampling events, or because the flow contribution from various conduits supplying springflow may fluctuate with time.

Water samples from 35 wells and three springs of the Silver Springs group also were analyzed for a suite of 63 compounds commonly found in domestic and industrial wastewater to gain additional insight into the sources of nitrogen in ground water and in water from Silver Springs. Compounds found in detergents and personal care products, pesticides, and compounds that result from industrial processes were included. Some of the compounds are known or suspected endocrine disrupters. A total of 38 compounds was detected, nearly all in very low concentrations. The most frequently detected compound was the insecticide N,N-diethyl-meta-toluamide (DEET), which was detected in water from 27 wells and all three spring samples. The presence or absence of DEET in ground-water samples did not seem to be related to land use, but geologic conditions at well sites generally did affect the presence or absence of DEET in the ground water. DEET appears to be a useful tracer for the presence of wastewater.

In January 2002, water samples were collected from the Main Spring, the Abyss, and the Blue Grotto of the Silver Springs group and analyzed for concentrations of dissolved gasses and for chlorofluorocarbons (CFCs), sulfur hexafluoride, and tritium/helium-3 for the purpose of dating the young fraction of ground water. Apparent ground-water ages are based on a piston-flow model, which may not adequately represent a more complex flow system. Apparent age for water from the Main Spring is about 27 years for tritium/helium-3 data compared to about 15 years based on sulfur hexafluoride. For the Abyss, the tritium/helium- 3 age is about 9 years; the sulfur hexafluoride age is about 8 years. For the Blue Grotto, tritium/helium-3 age is about 19 years, whereas the sulfur hexafluoride age is about 6 years. These results indicate that the flow system to the Abyss may be simple and adequately represented by the piston flow model. The flow systems of the Main Spring and the Blue Grotto, however, are more complex and likely include water that contains terrigenic $\mathrm{SF}_{6}$ and originates from a deeper flow zone. CFC data could not be used for dating because all spring samples contained higher than equilibrium concentrations of CFCs.

All three springs (the Main Spring, the Abyss, and the Blue Grotto) are affected by the presence of wastewater in the contributing area, as evidenced by the presence of DEET and elevated CFC concentrations in all the samples. The complex conduit flow system contributing water to Silver Springs makes it difficult to draw conclusions about the time lag between introduction of nitrogen loads in the basin and nitrate- $\mathrm{N}$ concentrations in the spring water. However, the fact that water from the spring is relatively young (less than 30 years) indicates it likely is important to minimize nitrogen loading within the contributing area of 30-year travel times or less. 


\section{Selected References}

Aeschbach-Hertig, W., Schlosser, P., Stute, M., Simpson, H.J., Ludin, A., and Clark, J.F., 1998, A ${ }^{3} \mathrm{H} /{ }^{3} \mathrm{He}$ study of ground water flow in a fractured bedrock aquifer: Ground Water, v. 36, no. 4, p. 661-670.

Berndt, M.P., 1996, Ground-water quality assessment of the Georgia-Florida Coastal Plain study unit-Analysis of available information on nutrients, 1972-92: U.S. Geological Survey Water-Resources Investigations Report 95-4039, 39 p.

Böhlke, J.K., and Coplen, T.B., 1995, Interlaboratory comparison of reference materials for nitrogen-isotoperatio measurements, in Reference and intercomparison materials for stable isotopes of light elements, International Atomic Energy Agency, TECDOC 825, p. 51-66.

Böhlke, J.K., and Denver, J.M., 1995, Combined use of ground water dating, chemical and isotopic analyses to resolve the history and fate of nitrate contamination in two agricultural watersheds, Atlantic coastal plain, Maryland: Water Resources Research, v. 31, no. 9, p. 2319-2339.

Bradner, L.A., and Knowles, Leel, Jr., 1999, Pontentiometric surface of the Upper Floridan aquifer in the St. Johns River Water Management District and vicinity, May 1999: U.S. Geological Survey Open-File Report 99-608, 1 map sheet.

Busenberg, E., and Plummer, L.N., 1992, Use of chlorofluorocarbons $\left(\mathrm{CCl}_{3} \mathrm{~F}\right.$ and $\left.\mathrm{CClF}_{2}\right)$ as hydrologic tracers and age-dating tools: The alluvium and terrace system of central Oklahoma: Water Resources Research, v. 28, no. 9, p. 2257-2283.

Busenberg, E., and Plummer, L.N., 2000, Dating young ground water with sulfur hexafluoride; Natural and anthropogenic sources of $\mathrm{SF}_{6}$ : Water Resources Research, v. 36, no. 10, p. 3011-3030.

Busenberg, E., Weeks, E., Plummer, L.N., and Bartholemay, R.C., 1993, Age dating ground water by use of chlorofluorocarbons $\left(\mathrm{CCl}_{3} \mathrm{~F}\right.$ and $\left.\mathrm{CCl}_{2} \mathrm{~F}_{2}\right)$, and distribution of chlorofluorocarbons in the unsaturated zone, Snake River Plain aquifer, Idaho National Engineering Laboratory, Idaho: U.S. Geological Survey WaterResources Investigations Report 93-4054, 47 p.

Buxton, H.T., and Kolpin, D.W., 2002, Pharmaceuticals, hormones, and other organic wastewater contaminants in U.S. Streams: U.S. Geological Survey Fact Sheet 027-02, $4 \mathrm{p}$.
Cathcart, J.B., 1992, Uranium in phosphate rock, with special reference to the central Florida deposits, in Dickinson, K.A., ed., Short papers of the U.S. Geological Survey uranium workshop: U.S. Geological Survey Circular 1069, p. 32-35.

Chelette, Angela, Pratt, T.R., and Katz, B.G., 2002, Nitrate loading as an indicator of nonpoint source pollution in the lower St. Marks-Wakulla Rivers watershed: Northwest Florida Water Management District Water Resources Special Report 02-1, 138 p.

Cook, P.G., and Böhlke, J.K., 2000, Determining timescales for groundwater flow and solute transport, in Cook, P.G., and Herzeg, A.L., eds., Environmental tracers in subsurface hydrology: Boston, Kluwer Academic Press, p. 1-30.

Coplen, T.B., 1993, Uses of environmental isotopes, in Alley, W.M., ed., Regional Ground-Water Quality: New York, Van Nostrand Reinhold, p. 227-254.

Crandall, C.A., 2000, Distribution, movement, and fate of nitrate in the surficial aquifer beneath citrus groves, Indian River, Martin, and St. Lucie Counties, Florida: U.S. Geological Survey Water Resources Investigations Report 00-4057, 69 p.

Environmental Resources Management-South, Inc., 1988, Final contamination assessment report for West Florida Natural Gas Company, Ocala, Florida: Tampa, Fla.

Faulkner, G.L., 1973, Geohydrology of the cross-Florida barge canal area with special reference to the Ocala vicinity: U.S. Geological Survey Water-Resources Investigations Report 1-73, 117 p.

Florida Department of Environmental Protection, 2003, Very Intensely Studied Area (VISA) network, [accessed 10/15/03] http://www.dep.state.fl.us/ water/monitoring/visa_net.htm.

Geotrans, Inc., 1988, Hydrologic investigation of the northern part of the Southwest Florida Water Management District: Herndon, Va.

German, E.R., 1996, Analysis of nonpoint-source groundwater contamination in relation to land use: Assessment of nonpoint-source contamination in central Florida: U.S. Geological Survey Water-Supply Paper 2381-F, $60 \mathrm{p}$.

Gonfiantini, R., 1981, The $\delta$-notation and the mass-spectrometric measurement technique, in Gat, J.R., and Gonfiantini, R., eds., Stable isotope hydrology: Deuterium and oxygen-18 in the water cycle, chap. 4, p. 3584, International Atomic Energy Agency, Vienna, Austria. 
Hallberg, G.R., and Keeney, D.R., 1993, Nitrate, in Alley, W.A., ed., Regional Ground-Water Quality: New York, Van Nostrand Reinhold, chap. 12, p. 297-322.

Harbaugh, A.W., 1990, A computer program for calculating subregional water budgets using results from the U.S. Geological Survey modular three-dimensional finite-difference ground-water flow model: U.S. Geological Survey Open-File Report 99-392, 46 p.

Harris, B., 2004, Investigation of the atmospheric deposition of N, United Kingdom Environment Agency, [accessed 05/28/04] http://www.uk-adapt.org.uk/find/ ?action $=$ project\&id $=80$.

Heberer, Thomas, 2002, Tracking persistent pharmaceutical residues from municipal sewage to drinking water: Journal of Hydrology, v. 266, no. 3-4, p. 175-189.

Hem, J.D., 1985, Study and interpretation of the chemical characteristics of natural water: U.S. Geological Survey Water-Supply Paper 2254 (3rd. ed.), 263 p.

Horsley, S.W., Santos, D., and Busby, D., 1996, Septic system impacts for the Indian River Lagoon, Florida, [accessed 01/10/02] http://www.epa.gov/OWOW/ watershed/Proceed/horsley.html.

Howarth, R., and Rielinger, D.M., 2004, Nitrogen from the atmosphere: Understanding and reducing a major cause of degradation in our coastal waters: Science and Policy Bulletin No. 8, Waquoit, Massachusetts, Massachusetts Department of Environmental Management, [accessed 05/28/04] http://www.waquoitbayreserve. org/SP/sp_8.pdf.

Hubner, H., 1986, Isotope effects of nitrogen in the soil and bioshpere, in Fritz, P. and Fontes, J.C., eds., Handbook of environmental geochemistry, v. 2, The terrestrial environment B: New York, Elsevier Publishing Co., p. 361-425.

Insightful Corporation, 2001, S-plus 6 for windows guide to statistics, v. 1: Seattle, Insightful Corporation.

Jansson, S.L., and Person, J., 1982, Mineralization and immobilization of soil nitrogen, in Stevenson, F.J., ed., Nitrogen in agricultural soils: Agronomy, A series of Monographs, chap. 6, no. 22, Madison, Wisconsin, American Society of Agronomy, p. 229-252.

Jones, D.W., Freeman, C.E., Johnson, J.T., and Whitty, E.B., 1974, Fertilizer recommendations for agronomic crops in Florida: Soil and Crop Science Society of Florida, v. 33, p. 43-45.

Jones, G.W., Upchurch, S.B., and Champion, K.M., 1996, Origin of nitrate in ground water discharged from Rainbow Springs, Marion County, Florida: Southwest Florida Water Management District publication, 155 p.
Katz, B.G., 2004, Sources of nitrate contamination and age of water in large karstic springs of Florida: Environmental Geology, v. 46, p. 689-706.

Katz, B.G., and Bohlke, J.K., 2000, Monthly variability and possible sources of nitrate in ground water beneath mixed agricultural land use, Suwannee and Lafayette Counties, Florida: U.S. Geological Survey WaterResources Investigations Report 00-4219, 28 p.

Katz, B.G., Hornsby, H.D., Bohlke, J.K., and Mokray, M.F., 1999, Sources and chronology of nitrate contamination in spring waters, Suwannee River basin, Florida: U.S. Geological Survey Water-Resources Investigation Report 99-4252, 54 p.

Keenan, C.W., and Wood, J.H., 1971, General college chemistry, 4th ed.: New York, Harper and Row, 717 p.

Kidder, G., Hanlon, E.A., and Chambliss, C.G., 1998, UF/IFAS standard fertilizer recommendations for agronomic crops: Gainesville, University of Florida, Florida Cooperative Extension Service, Institute of Food and Agricultural Sciences SL-129, 7 p.

Kimrey, J.O., and Fayard, L.D., 1984, Geohydrologic reconnaissance of drainage wells in Florida: U.S. Geological Survey Water Resources Investigations Report 84-4021, 67 p.

Kinnaman, S.L., and Knowles, Leel, 2002, Potentiometric surface of the Upper Floridan aquifer in the St. Johns River Water Management District, May 2002: U.S. Geological Survey Open-File Report 02-434, 1 map sheet, scale 1:100,000.

Kinnaman, S.L., and Knowles, Leel, 2003, Potentiometric surface of the Upper Floridan aquifer in the St. Johns River Water Management District, September 2002: U.S. Geological Survey Open-File Report 03-209, 1 map sheet, scale 1:100,000.

Knochenmus, D.W., 1967, Tracer studies and background fluorescence of ground water in the Ocala, Florida, area: U.S. Geological Survey Open-File Report 67004, $35 \mathrm{p}$.

Knowles, Leel, 1996, Estimation of evapotranspiration in the Rainbow Springs and Silver Springs basins in northcentral Florida: U.S. Geological Survey WaterResources Investigations Report 96-4024, 37 p.

Ludin, A., Weppernig, R., Bonisch, G., and Schlosser, P., 1998, Mass spectrographic measurement of helium isotopes and tritium: Lamont-Doherty Earth Observatory, Palisades, N.Y., Technical Report 98-06. 
Madison, R.J., and Brunett, J.O., 1985, Overview of the occurrence of nitrate in ground water in the United States, in National Water Summary 1984-Hydrologic events, selected water-quality trends, and ground-water resources: U.S. Geological Survey Water-Supply Paper 2275, p. 93-105.

Mariotti, A., Landreau, A., and Simon, B., 1988, N-15 isotope biochemistry and natural denitrification processed in ground water: Application to the chalk aquifer of northern France: Geochemica et Cosmochimica Acta, v. 52, no. 7, p. 1869-1878.

Merritt, M.L., 1998, Potentiometric surface of the Upper Floridan aquifer in the St. Johns River Water Management District and vicinity, Florida, September 1997: U.S. Geological Survey Open-File Report 98-183, 1 map sheet, scale 1:100,000.

Michel, R.M., 1989, Tritium deposition in the United States 1953-1983: U.S. Geological Survey WaterResources Investigations Report 89-4072, 46 p.

Miller, J.A., 1986, Hydrogeologic framework of the Floridan aquifer system in Florida and in parts of Georgia, Alabama, and South Carolina: U.S. Geological Survey Professional Paper 1403-B, 91 p.

National Atmospheric Monitoring Deposition Program, 2002, [accessed 9/20/01] http://nadp.sws.uiuc.edu/ nadpdata/siteinfo. asp?id= FL03\&net=NTN .

National Oceanic and Atmospheric Administration, 2003, Climatological data annual summary, Florida, v. 107, no. 13, Asheville, N.C., variously paged.

Nordlie, F.G., 1990, Rivers and springs, in Myers, R.L. and Ewel, J.J., eds., Ecosystems of Florida, chap. 12: Orlando, University of Central Florida Press, p. 392-425.

Otis, R.J., Anderson, D.L., and Apfel, R.A., 1993, Onsite sewage disposal system research in Florida: Report prepared for Florida Department of Health and Rehabilitative Services, Contract No. LP-596, Ayres and Associates, Tampa, Fla., 57 p.

Phelps, G.G., 1994, Hydrogeology, water quality, and potential for contamination of the Upper Floridan aquifer in the Silver Springs ground-water basin, central Marion County, Florida: U.S. Geological Survey Water-Resources Investigations Report 92-4159, 69 p.

Pidwirny, M.J., 2003, The nitrogen cycle [accessed 12/22/03] http://www.physicalgeography.net/ fundamentals/9s.html.

Plummer, L.N., Busby, J.F., Lee, R.W., and Hanshaw, B.B., 1990, Geochemical modeling of the Madison aquifer in parts of Montana, Wyoming, and South Dakota: Water Resources Research, v. 26, no. 9, p. 1981-2014.
Plummer, L.N., and Busenberg, E., 2000, Chlorofluorocarbons, in Cook, P.G., and Herczeg, A., eds., Environmental tracers in subsurface hydrology: Boston, Kluwer Academic Publishers, p. 441-478.

Plummer, L.N., Busenberg, E., Drenkard, S., Schlosser, P., Ekwurzel, B., Weppernig, R., McConnell, J.B., and Michel, R.L., 1998, Flow of river water into a karstic limestone aquifer. 2. Dating the young fraction in groundwater mixtures in the Upper Floridan aquifer near Valdosta, Georgia: Applied Geochemistry, v. 13, no. 8, p. 1017-1043.

Plummer, L.N., Michel, R.L., Thurman, E.M., and Glynn, P.D., 1993, Environmental tracers for age-dating young ground water, in Alley, W.M., ed., Regional groundwater quality: New York, Van Nostrand Reinhold, p. 255-294.

Pollock, D.W., 1989, Documentation of computer programs to compute and display pathlines using results from the U.S. Geological Survey modular three-dimensional finite-difference ground-water flow model: U.S. Geological Survey Open-File Report 89-381, 188 p.

Pollock, D.W., 1994, User's guide for MODPATH/ MODPATH-PLOT, version 3, a particle-tracking post processing package for MODFLOW, the U.S. Geological Survey finite-difference ground-water flow model: U.S. Geological Survey Water-Resources Investigations Report 98-4080.

Reilly, T.E., Plummer, L.N., Phillips, P.J., and Busenberg, E., 1994, The use of simulation and multiple environmental tracers to quantify groundwater flow in a shallow aquifer: Water Resources Research, v. 30, no. 2, p. 421-433.

Sacks, L.A., 1996, Geochemical and isotopic composition of ground water with emphasis on sources of sulfate in the Upper Floridan aquifer in parts of Marion, Sumter, and Citrus Counties, Florida: U.S. Geological Survey Water-Resources Investigations Report 95-4251, 47 p.

St. Johns River Water Management District, 1999, Land use/Land cover -1995, v 2.0, [accessed 12/22/03] http://sjr.state.fl.us/programs/outreach/pubs/ index.html.

Schlosser, Peter, 1992, Tritium $/{ }^{3} \mathrm{He}$ dating of waters in natural systems, in Isotopes of noble gases as tracers in environmental studies: International Atomic Energy Agency, Vienna, p. 123-145.

Schlosser, Peter, Stute, Martin, Sonntag, Christian, and Munnich, K.O., 1989, Tritogenic ${ }^{3} \mathrm{He}$ in shallow ground water: Earth Planetary Science Letters, v. 94, no. 3-4, p. 245-256. 
Scott, T.M., 1988, Lithostratigraphy of the Hawthorn Group (Miocene) of Florida: Florida Geological Survey Bulletin 59, 148 p.

Scott, T.M., Campbell, K.M., Rupert, F.R., Arthur, J.D., Missimer, T.M., Lloyd, J.M., Yon, J.W., and Duncan, J.G., 2001, Geologic map of the State of Florida: Florida Geological Survey Map Series 146, 1 map sheet, [accessed 12/16/2003] http://www.dep.state.fl.us/ geology/gisdatamaps/index.htm.

Scott, T.M., Means, G.H., Means, R.C., and Meegan, R.P., 2002, First magnitude springs of Florida: Florida Geological Survey Open-File Report No. 85, 138 p.

Sepúlveda, Nicasio, 2002, Simulation of ground-water flow in the intermediate and Floridan aquifer systems in peninsular Florida: U.S. Geological Survey WaterResources Investigations Report 02-4009, 130 p.

Shoemaker, W.B., O’Reilly, A.M., Sepúlveda, Nicasio, Williams, S.A., Motz, L.H., and Sun, Qing, 2003, Comparison of estimated areas contributing recharge to selected springs in north-central Florida by using multiple ground-water flow models: U.S. Geological Survey Open-File Report 03-448, 31 p.

Solomon, D.K., and Sudicky, E.A., 1991, Tritium and helium-3 isotope ratios for direct estimation of spatial variations in groundwater recharge: Water Resources Research, v. 27, no. 9, p. 2309-2319.

Stevenson, F.J., 1982, Origin and distribution of nitrogen in soil, in Stevenson, F.J., ed., Nitrogen in agricultural soils: Agronomy, A series of Monographs, chap. 1, no. 22, Madison, Wisconsin, American Society of Agronomy, p. 1-42.

Stricker, J.A., and Muraro, R.P., 1981, Determining most profitable level of nitrogen fertilization for citrus: Proceedings, Florida State Horticultural Society, v. 94, p. 8-11.

Sumner, D.M., and Bradner, L.A., 1996, Hydraulic characteristics and nutrient transport and transformation beneath a rapid infiltration basin, Reedy Creek Improvement District, Orange County, Florida: U.S. Geological Survey Water-Resources Investigations Report 95-4281, 51 p.

Thayer, P.A., and Miller, J.A., 1984, Petrology of lower and middle Eocene rocks, Floridan aquifer, central Florida: Transactions, Gulf Coast Association of Geological Societies, v. 34, p. 421-434.

Tibbals, C.H., 1975, Aquifer tests in the Summit reach of the proposed Cross-Florida Barge Canal near Ocala, Florida: U.S. Geological Survey Water-Resources Investigations $28-75,42 \mathrm{p}$.
Toth, D.J., 1999, Water quality and isotope concentrations from selected springs in the St. Johns River Water Management District: St. Johns River Water Management District Technical Publication SJ99-2, 67 p.

Toth, D.J., 2003, Water quality and isotope concentrations from selected springs in the St. Johns River Water Management District: St. Johns River Water Management District Technical Publication SJ2003-1, 70 p.

Toth, D.J., and Fortich, Carlos, 2002, Nitrate concentrations in the Wekiwa ground water basin with emphasis on Wekiwa Springs: St. Johns River Water Management District Technical Publication 2002-2, 86 p.

U.S. Census Bureau, 2002, Florida: Population of counties by decennial census: 1900-1990, ed., Forstall, R.L., [accessed 9/29/2004] http://factfinder.census.gov/servlet/DatasetMainPageServlet?_lang=en\&_ts=1145251 33172\&_ds_name $=$ DEC_1990_STF1_\&_program $=$.

U.S. Department of Agriculture, 1997, 1997 census of agriculture, v. 1, part 9, chap. 2, Florida county-level data, [accessed 9/15/03] http://www.nass.usda.gov/ census/census97/ volume1/fl-9/ toc97.htm.

U.S. Environmental Protection Agency, 1998, R.E.D. Facts: DEET: EPA-738-F-95-010, [accessed Sept. 2003] http:// www.epa.gov/oppsrrd1/REDs/ factsheets/0002fact.pdf.

U.S. Environmental Protection Agency, 2003, Current drinking water standards, [accessed Sept. 2003] http://www.epa.gov/safewater/mcl.html\#mcls.

U.S. Geological Survey, 1990, Land use and land cover digital data from 1:250,000- and 1:100,000-scale maps: Data Users Guide, 33 p.

U.S. Geological Survey, 1997-2003, National field manual for the collection of water-quality data: U.S. Geological Survey Techniques of Water-Resources Investigations, book 9, chap. A1-A9, 2 v., variously paged [Also available at http://pubs.water.usgs.gov/ twri9A; updates and revisions are ongoing and are available at http://water.usgs.gov/owq/FieldManual/ masterrata.html].

U.S. Geological Survey, 1998, County-based estimates of nitrogen and phosphorus content of animal manure in the United States for 1982, 1987, and 1992, [accessed 9/20/01] http://water.usgs.gov/GIS/metadata/usgswrd/ manure.html.

U.S. Geological Survey, 1999, Comprehensive quality assurance plan prepared for the Florida District by the U.S. Geological Survey Quality of Water Service Unit, Ocala, Florida. 
U.S. Geological Survey, 2003a, Estimated total water withdrawals in Florida by county, 2000, [accessed 9/10/03] http://fl.water.usgs.gov/WaterUse/Water_ Use_web/ data_tables_202000.htm.

U.S. Geological Survey, 2003b, Water resources data, Florida, Water year 2002, Vol. 1A Northeast Florida Surface Water, $401 \mathrm{p}$.

Wood, W.W., 1976, Guidelines for collection and field analysis of ground-water samples for selected unstable constituents: U.S. Geological Survey Techniques of Water-Resources Investigations, book 1, chap. D2, 24 p.

Zaugg, S.D., Smith, S.G., Schroeder, M.P., Barber, L.B., and Burkhardt, M.R., 2002, Methods of analysis by the U.S. Geological Survey National Water Quality
Laboratory-Determination of wastewater compounds by polystyrene-divinylbenzene solid-phase extraction and capillary-column gas chromatography/mass spectrometry: U.S. Geological Survey Water-Resources Investigations Report 01-4186, 37 p.

Zuber, A., 1986, Mathematical models for the interpretation of environmental radioisotopes in groundwater systems, in Fritz, P., and Fontes, J.C., eds., Handbook of Environmental Geochemistry, v. 2, The terrestrial environment: New York, Elsevier Publishing Company, p. 1-59. 
48 Chemistry of Ground Water in the Silver Springs Basin, Florida, with an Emphasis on Nitrate 
Appendixes 


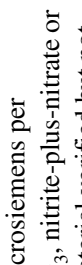

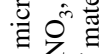

竞 + क

जิ

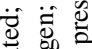

苟

官

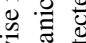

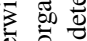

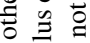

总完

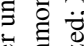

氖

离范

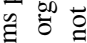

政 +

言年

政

有

के

造

월

跑

政

흥

啨

三 家计

包

总论

猔

完

용

氛产

흥 눙

용

品

응

ชิ่

市

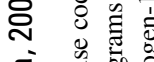

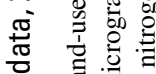

$x$ 表

政

잉

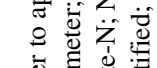

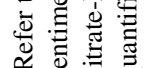

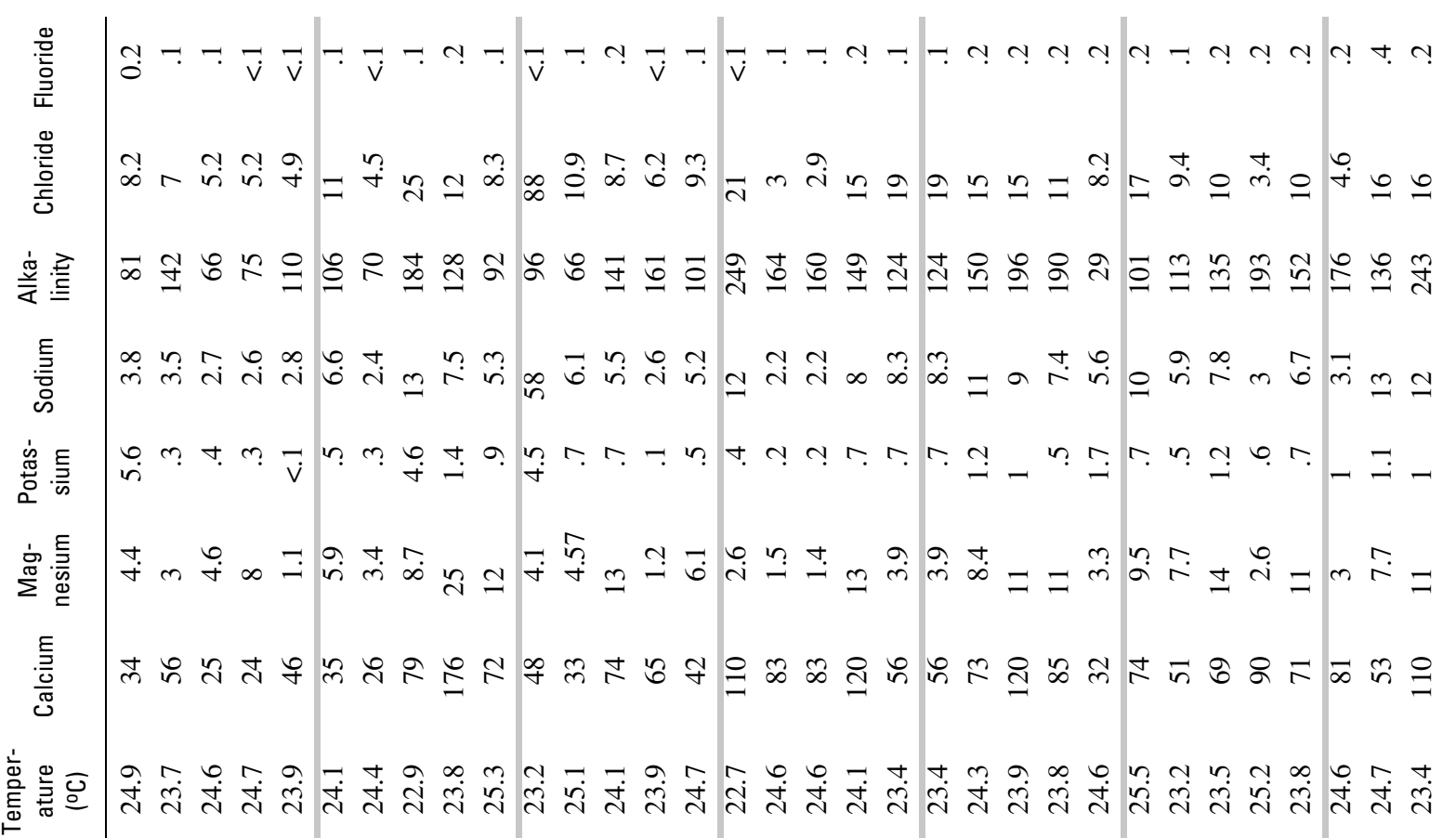

흥 튼

कू क्ड

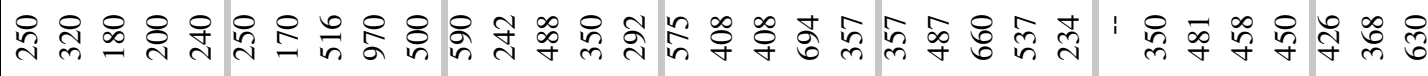

으 $\overline{\mathrm{E}}$

它突

导

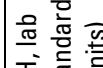

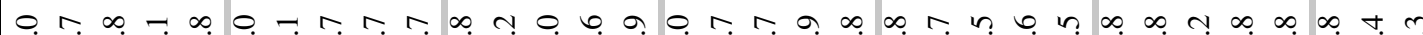
台㥕

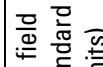
容密

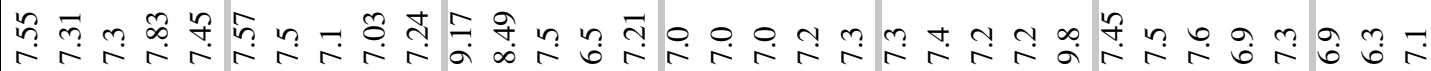

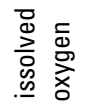

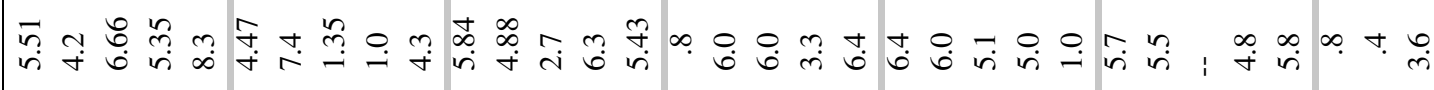
号文

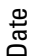

రీ .

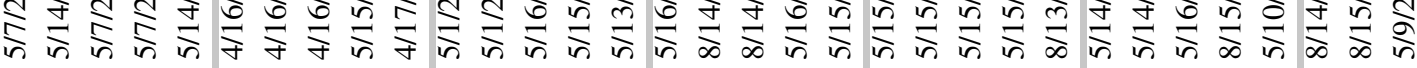

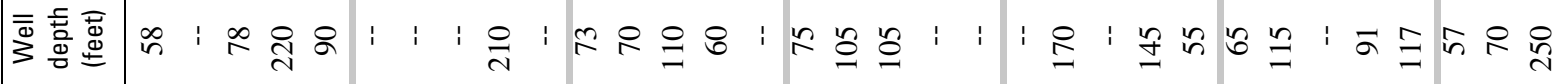

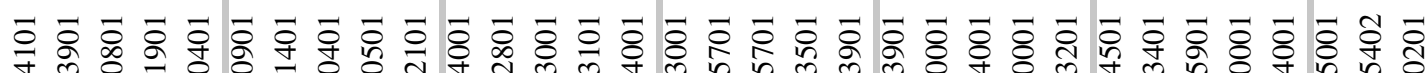

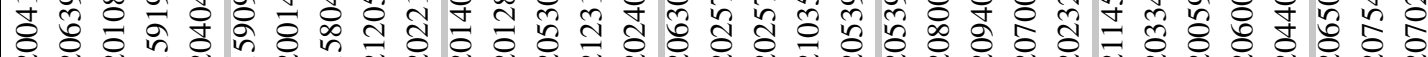

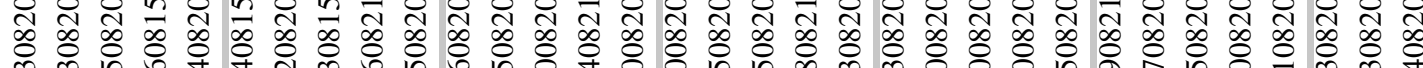

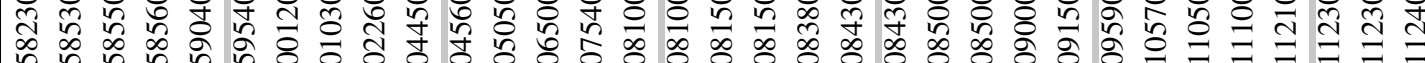
苮

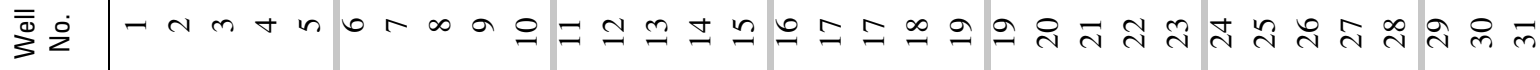




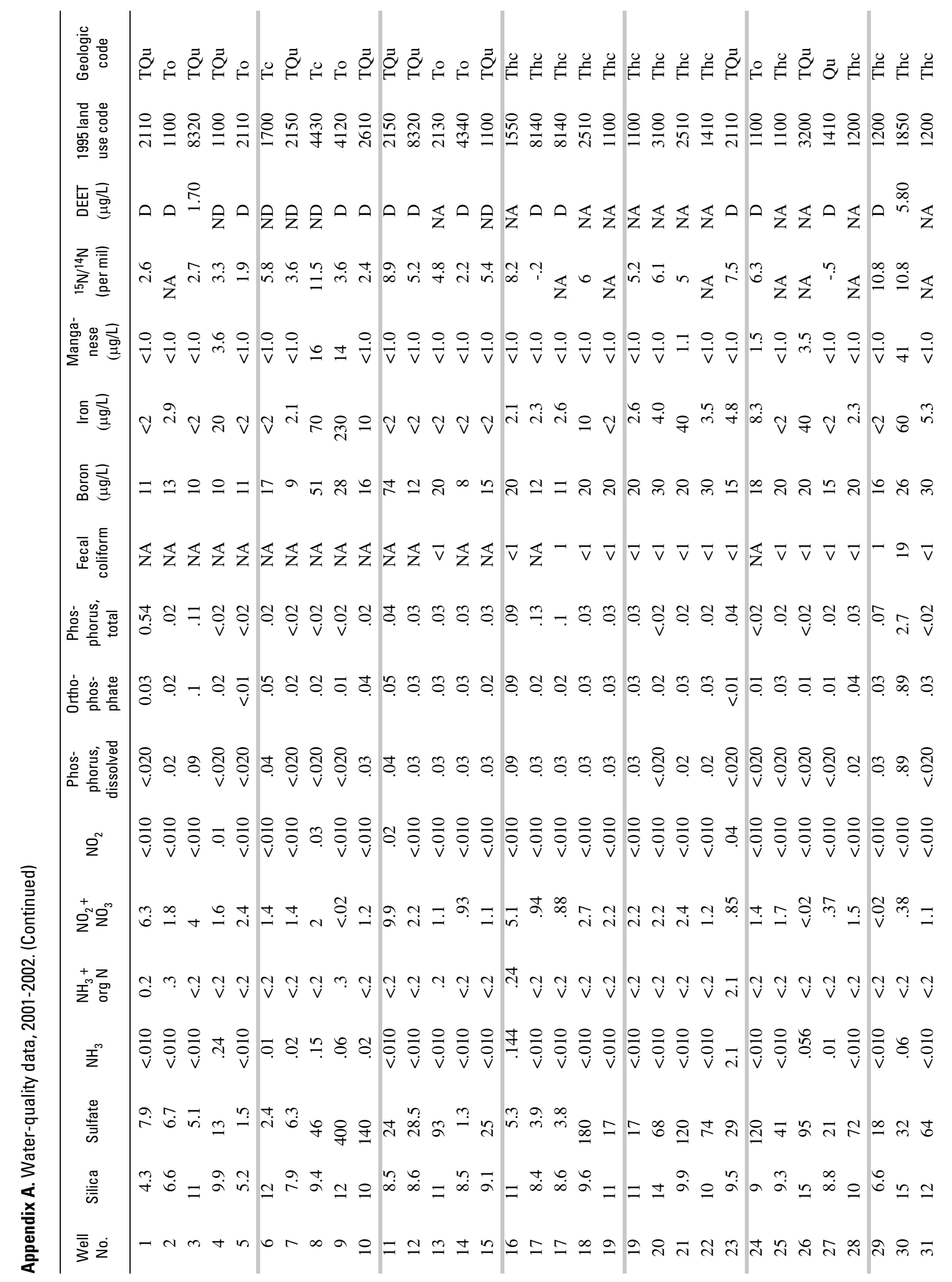




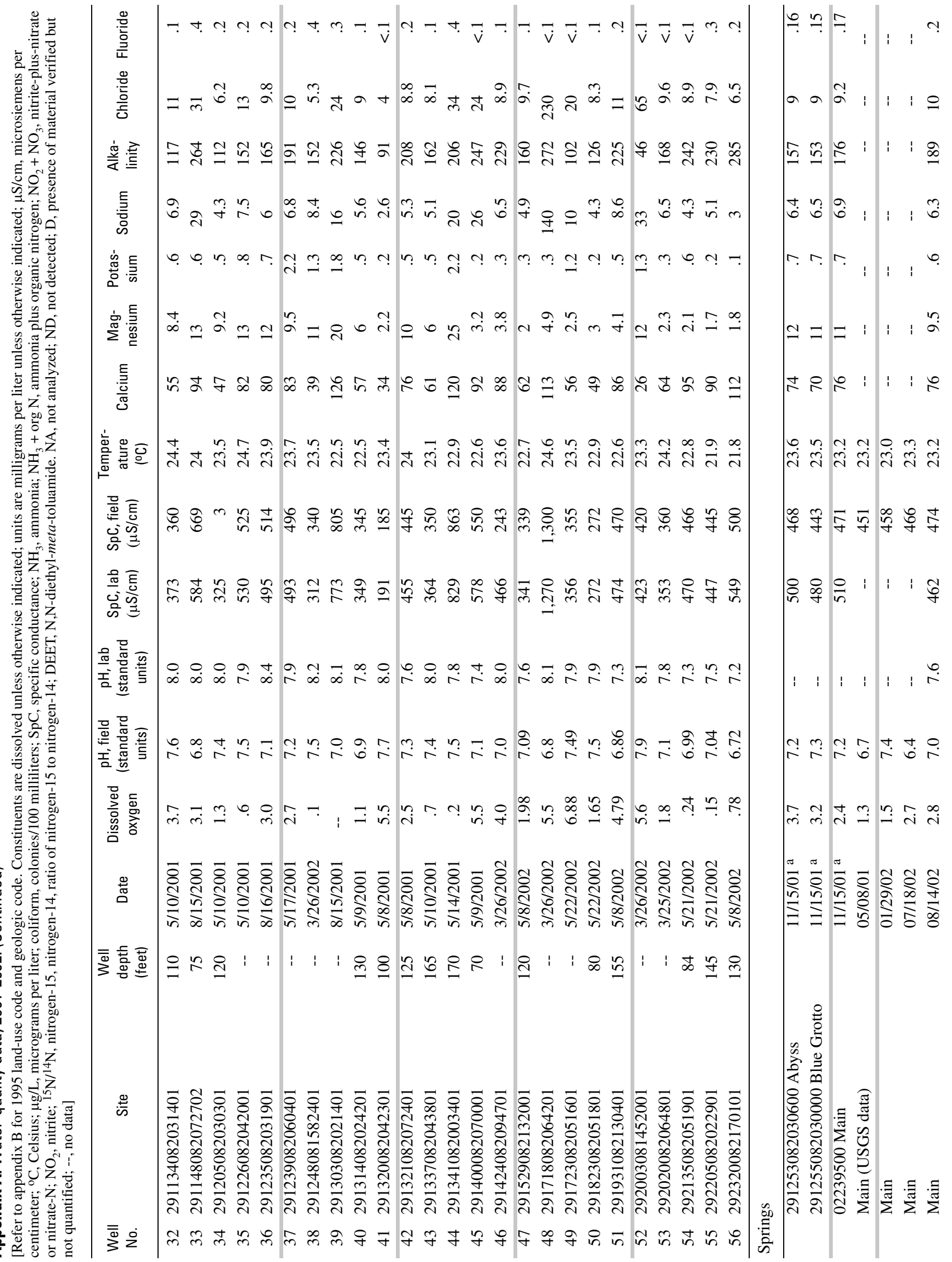




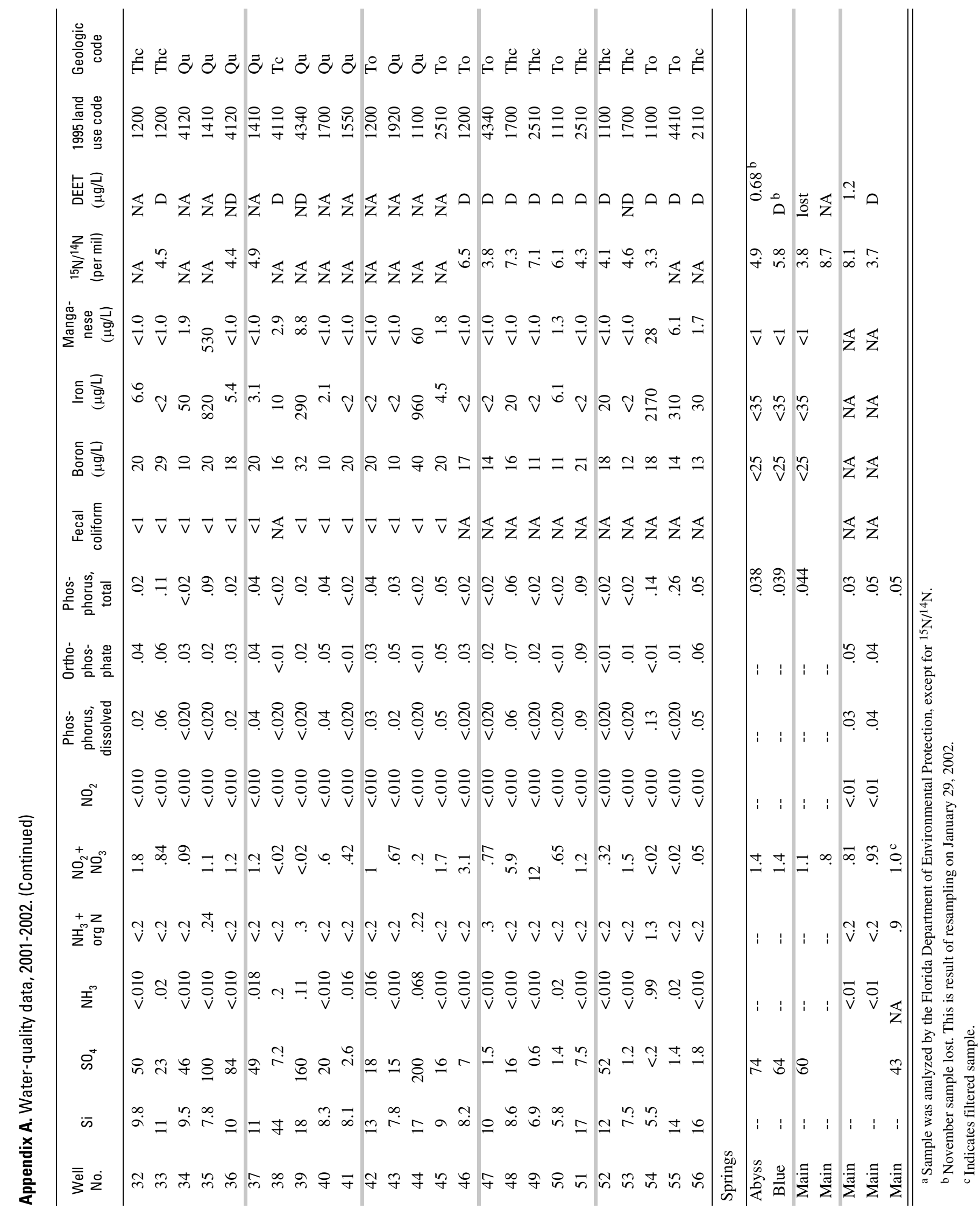


Appendix B. Land-use and geologic codes.

[Source of 1995 land-use codes: St. Johns River Water Management District, 1999; source of geologic codes: Scott and others, 2001]

1995 Land-Use Codes (LUCODE)

Urban:

1000-1199 Low-density residential (less than 2 dwelling units per acre)

1200-1399 Medium and high-density residential (more than 2 dwelling units per acre)

1400-1799 Commercial/Industrial

1800-2000 Recreation/Open land

Agricultural:

$\begin{array}{ll}2110-2133 & \text { Pasture } \\ 2140-2160 & \text { Croplands } \\ 2300-2333 & \text { Livestock operations } \\ 2510 & \text { Horse farms } \\ 2610 & \text { Fallow croplands }\end{array}$

Rangeland:

3000-3999 Rangeland

Upland forests:

4000-4999 Upland forests

Water:

5000-5999 Water

Wetlands:

6000-6999 Wetlands

Barren lands:

7000-7999 Barren lands

Transportation, communications, and utilities:

$8100 \quad$ Transportation

$8200 \quad$ Communications

$8300 \quad$ Utilities

8340 Sewage treatment plants

\section{Geologic Codes}

Tc Tertiary Cypresshead Formation

The Tertiary Hawthorn Group

To Tertiary Ocala Limestone

TQu Tertiary-Quaternary undifferentiated sediments

$\mathrm{Qu} \quad$ Quaternary undifferentiated sediments 